Universidade de São Paulo

Faculdade de Filosofia, Letras e Ciências Humanas

Departamento de Filosofia

\title{
A natureza das normas: o vital e o social na filosofia de Georges Canguilhem
}

- Fábio Luís Ferreira Nóbrega Franco - 


\author{
Universidade de São Paulo \\ Faculdade de Filosofia, Letras e Ciências Humanas \\ Departamento de Filosofia
}

\title{
A natureza das normas: o vital e o social na filosofia de Georges Canguilhem
}

- Fábio Luís Ferreira Nóbrega Franco -

Dissertação apresentada ao programa de pós-graduação do Departamento de Filosofia, da Faculdade de Filosofia, Letras e Ciências Humanas, da Universidade de São Paulo, para obtenção do título de Mestre em Filosofia, sob orientação do Prof. Dr. Vladimir Pinheiro Safatle. 
Aos meus pais, Iraci Ferreira Franco e Gerson José Nóbrega Franco,

Ao Prof. Michel H. L. G. Paty 


\section{AGRADECIMENTOS}

Ao meu orientador, Prof. Dr. Vladimir Pinheiro Safatle, pela confiança que desde cedo depositou nesta pesquisa. Certamente, ela é herdeira de reflexões e questionamentos que seus cursos, conferências e publicações me ensejaram.

A Profa. Dra. Marilena Chaú, pelo estímulo, intelectual e pessoal, que marcaram indelevelmente minha formação filosófica. Sua disponibilidade para ler esta dissertação, assim como suas perspicazes e sempre pertinentes observações, foram determinantes para as escolhas teóricas tomadas durante o desenvolvimento da pesquisa.

A todos os que viabilizaram meu estágio de pesquisa em Paris, sem o qual esta dissertação não teria amadurecido, particularmente ao Prof. Dr. Michel Paty, grande amigo e incentivador intelectual, ao Prof. Dr. Camille Limoges, pelas reflexões que me levaram ao tema desta dissertação, ao Prof. Dr. Claude Debru, a Equipe de Recherche en Épistémologie et Histoire des Sciences (Equipe REHSEIS), em particular ao Prof. Dr. David Rabouin e ao Prof. Dr. Jean-Jacques Szczeciniarz, a Nathalie Queyroux e a David Dénechaud, pela valiosa atenção que me dedicaram durante minha estada de pesquisa nos Archives Canguilhem, ao Prof. Dr. Giuseppe Bianco, pela imprescindível interlocução e pela disponibilidade para participar da minha banca de defesa.

Aos amigos do Laboratório de Teoria Social, Filosofia e Psicanálise (LATESFIP-USP), especialmente àqueles com quem trabalhei no saudoso "grupo Canguilhem", ao Prof. Dr. Herivelto Souza, pelo acompanhamento atento e generoso desta pesquisa desde sua gestação, ao Prof. Dr. Christian Dunker, pelo encorajamento em períodos turbulentos da pesquisa, a Ronaldo Manzi Filho, pelas tardes maiêuticas com pequi, a Rafael Gargano, pelas reflexões em ônibus e "bandeijões", aos amigos do "grupo Paranoia", no interior do qual parte desta pesquisa foi gestada em reuniões que cruzavam madrugadas.

Aos amigos do "grupo de orientação", que acompanharam as várias alterações pelas quais passou esta pesquisa. Certamente devo a eles muito daquilo que, neste trabalho, possuir algum interesse filosófico. Agradeço particularmente ao amigo Eduardo Socha, pela partilha de questões que extrapolavam os limites, por vezes estreitos, de uma pesquisa acadêmica.

A todos os amigos da Universidade de São Paulo, especialmente àqueles da Faculdade de Filosofia, Letras e Ciências Humanas, do Instituto de Psicologia, da Escola de Comunicação e Artes. Gostaria de agradecer especialmente aos amigos da gestão "Política contra a Barbárie", na Associação de Pós-graduandos da USP Capital, e do Fórum pela Democratização da USP, pela compreensão para com as minhas repetidas ausências em reuniões neste momento em que a participação discente deveria se consolidar contra a política autoritária e repressiva da Universidade de São Paulo.

As secretárias do Departamento de Filosofia, em particular a Geni Ferreira Lima, a Maria Helena de Souza e a Marie Márcia Pedroso, que me abriram várias sendas em meio aos labirintos da burocracia acadêmica.

A Ana Carolina Christ de Menezes Sousa, que alimentou as primeiras formulações 
desta pesquisa com a sua experiência médica.

A Bruna Martins Coelho, pelas provocações intelectuais que frequentemente deslocavam meu texto e meu pensamento.

A Daniel Nagase e a Dario de Negreiros, pelo raro e fecundo diálogo filosófico. Soulhes eternamente grato pela amizade.

A Sérgio Augusto Roberti dos Santos, que, numa certa noite a perder de vista, apresentou-me "O normal e o patológico".

A Catarina Gomes São Martinho, pela inesquecível experiência de uma vida normativa.

A Catarina Pedroso, pela velha e intensa amizade de poucos anos.

A Maria Rita Umeno Morita, pelos dias brancos - para o que der e vier!

Ao Prof. Dr. Mauro Castilho Gonçalves, que, desde o ginásio, estimulou a minha formação como pesquisador em Filosofia.

A Paulo Rona, pelo divã.

Aos meus pais, pelo amor.

Aos amigos de Taubaté, especialmente a Matheus Henrique, por 23 anos de amizade, e ao Côn. Carlos Antônio da Silva, pelos empréstimos de livros em línguas que só aprendi muitos anos depois.

Pela bolsa de mestrado, sou grato à Fundação de Amparo à Pesquisa do Estado de São Paulo (FAPESP). 
"Essayez de vous délivrer de quelques préjugés de plus, et vous vous apercevrez que votre défiance envers mon 'biologisme' était l'indice de votre adhésion à un a priori archaïque et non questionné: celui qui avait engendré la surinterprétation par les philosophes du 'décollage de l'inteligence et de la vie"'.

(Gérard Lebrun, De la supériorité du vivant humain dans L'Évolution Créatrice) 


\section{RESUMO}

FRANCO, Fábio Luís Ferreira Nóbrega. A natureza das normas: o vital e o social na filosofia de Georges Canguilhem. 2012. Dissertação (Mestrado) - Faculdade de Filosofia, Letras e Ciências Humanas. Departamento de Filosofia, Universidade de São Paulo, São Paulo, 2012.

A presente pesquisa pretende sustentar que a reflexão precoce sobre a sociologia durkheimeana cumpre um papel fundamental no desenvolvimento do pensamento de Georges Canguilhem sobre as ciências da vida e, por conseguinte, na elaboração da sua filosofia biológica. Como se buscará mostrar, essa importância se deve ao fato de que a teoria social de Durkheim procurou satisfazer às exigências científicas de objetividade e de quantificação dos fenômenos incorporando da biologia de Comte e da fisiologia de Claude Bernard a teoria da identidade essencial entre os estados normais e patológicos. Será a partir da crítica a essa teoria que o conceito de normatividade vital, núcleo da filosofia da vida canguilhemeana, se elaborará na tese de doutoramento de Canguilhem, em 1943, Essai sur quelques problèmes concernant le normal et le pathologique. Finalmente, concluiremos sugerindo que essa nova concepção de vida permitirá ao filósofo retornar ao campo da teoria social, nas Nouvelles réflexions, para recusar a identificação entre organismo e sociedade que ele denunciara em Durkheim.

Palavras-chave: Canguilhem - Teoria social - Ciências da vida - Normatividade - Vida 


\begin{abstract}
FRANCO, Fábio Luís Ferreira Nóbrega. The nature of norms: the vital and the social in Georges Canguilhem's philosophy. 2012. Thesis (Master Degree) - Faculdade de Filosofia, Letras e Ciências Humanas. Departamento de Filosofia, Universidade de São Paulo, São Paulo, 2012 .
\end{abstract}

The present research intends to sustain that the early reflection on Durkheim's sociology plays an important role in the evolution of George Canguilhem's thought about the life sciences, and, consequently, in the development of his biological philosophy. As this research purports to show, this importance arises from the fact that Durkheim's social theory attempted to satisfy the scientific demands for the objectivity and quantification of the phenomena by incorporating, from Comte's biology and Claude Bernard's physiology, a theory about the essential identity between normal and pathological states. It is by taking the critique of this theory as a starting point, that the core of Canguilhem's life philosophy, namely, his concept of vital normativity, will be developed in his 1943 doctorate thesis, Essai sur quelques problèmes concernant le normal et le pathologique. Finally, by way of conclusion, we suggest that this new conception of life will allow the French philosopher to return, in his Nouvelles réflexions, to the social theory field, in order to deny the same identification between organisms and society that he denounced in Durkheim.

Key words: Canguilhem - Social theory - Life sciences - Normativity - Life 


\section{SUMÁRIO}

INTRODUÇ̃̃O

PARTE I - UM CONCEITO DE SAÚDE: NORMA, NORMAL E MEDIDA

A DETERMINAÇÃO DO FATO: QUANTIFICAÇÃO E NORMALIDADE NAS CIÊNCIAS HUMANAS

9

A CONCEPÇÃO QUANTITATIVA DE SAÚDE E PATOLOGIA SOCIAIS, EM LES RÈGLES DE LA MEHODE SOCIOLOGIQUE 16

UMA ONTOLOGIA BIOLÓGICA DO SOCIAL

16
24

A GÊNESE BIOLÓGICA DA NORMALIDADE SOCIAL

30

UMA ESTÁTICA BIOLÓGICA: A FISIOLOGIA DE COMTE

32

O NASCIMENTO DA FISIOLOGIA EM CLAUDE BERNARD

PARTE II - NORMATIVIDADE VITAL: POR UMA FILOSOFIA NEGATIVA DA VIDA 50

DA TÉCNICA À VIDA

ANIMAIS E MÁQUINAS

O CONHECIMENTO VITAL DA VIDA

UMA TEORIA BIOLÓGICA DO MEIO

VALORAR É JULGAR: A POTÊNCIA VITAL DO JULGAMENTO

INDIVIDUALIDADE ORGÂNICA E NORMATIVIDADE VITAL

O VITALISMO NEGATIVO DE CANGUILHEM

PARTE III - NORMATIVIDADE SOCIAL

REGULAÇÃO BIOLÓGICA E REGULAÇÃO SOCIAL 


\section{Introdução}

Il faut remarquer qu'il y a toujours eu échange de bons ou mauvais procédés entre la sociologie et la biologie. C'est l'histoire seule qui, dans certains cas, nous permet d'eclairer l'origine de certains concepts auxquels une certaine équivocité en biologie et en sociologie

donne l'apparence d'avoir une équivalente dans l'une et l'autre domaines de significations et d'usages (Canguilhem, 1955, p. 66).

A importância filosófica de uma experiência intelectual não se pode mensurar pela quantidade de comentários que a tomam como objeto. Prova disto é que o pensamento de Georges Canguilhem continua pouco explorado mesmo no seu país natal, a França. São raros os grandes manuais de história da Filosofia que não o deixam na penumbra, reservando a ele um lugar marginal, no máximo um subcapítulo, nas páginas consagradas ao pensamento contemporâneo. No Brasil, as pesquisas sobre Canguilhem são ainda mais escassas. A partir de um levantamento que fizemos nas principais universidades do país, constatamos que não existe sequer uma tese ou dissertação dedicada exclusivamente ao comentário da filosofia canguilhemeana. Citado frequentemente como importante historiador das ciências nos departamentos de Filosofia, lido e reconhecido nas faculdades de saúde e de psicologia como o autor de "O normal e o patológico", sua ampla bibliografia permanece inacessível ao leitor brasileiro, já que, até o momento, apenas foram traduzidas ${ }^{1}$ a tese de doutorado de 1943, acrescida dos Nouvelles réflexions (1963-1966), e uma coletânea de textos tardios intitulada Escritos sobre a medicina.

Justificava-se essa tímida reverberação intelectual produzida nos meios acadêmicos por Canguilhem culpando-o pela sua produção parca, fragmentada, por vezes altamente técnica, resumida a suas teses e a uma porção de artigos coligidos em importantes publicações: Essai sur quelques problèmes concernant le normal et le pathologique (1943),

\footnotetext{
${ }^{1}$ Quando esta dissertação já se encaminhava para o seu fechamento, fomos notificados da recém-publicação no Brasil, pela editora Forense Universitária, de dois outros títulos fundamentais da obra canguilhemeana: Estudos de história e de filosofia das ciências e $O$ conhecimento da vida. Agradecemos essa informação ao nosso amigo, e privilegiado interlocutor, Prof. Dr. Herivelto Souza.
} 
La formation du concept de réflexe aux XVIIe. et XVIIIe. siècles (1955), Le normal et le pathologique (1966), La connaissance de la vie (2. ed. 1965), Études d'histoire et de philosophie des sciences (1968), Idéologie et rationalité dans l'histoire des sciences de la vie (1977). Essas obras, somadas a alguns outros trabalhos esparsos, pareciam dar conta de tudo quanto Canguilhem havia produzido ao longo de décadas dedicadas à pesquisa filosófica e à docência.

Contudo, atualmente, tal diagnóstico não mais se sustenta. $\mathrm{O}$ estabelecimento de uma extensa bibliografia crítica da obra canguilhemeana, realizado por Camille Limoges, cuja primeira versão data de $1994^{2}$, o artigo Canguilhem avant Canguilhem, que Jean-François Braunstein $^{3}$ torna público em 2000, a abertura dos Fonds Georges Canguilhem, em 2003, e a intensa pesquisa conduzida por Giuseppe Bianco, Guillaume le Blanc, Michele Cammeli, Xavier Roth e Yves Schwartz expuseram a amplitude e a complexidade da obra canguilhemeana até então pouquíssimo exploradas. São centenas de documentos - artigos, conferências, notas de estudo, projetos de pesquisa, aulas, resenhas, discursos, cartas - de difícil acesso para o grande público, que apenas agora estão sendo alvos de uma atenção especial dos estudiosos do pensamento francês contemporâneo.

De imediato, essas pesquisas contribuíram para redefinir os limites da produção bibliográfica canguilhemeana, antecipando seu marco inicial em, ao menos, dezessete anos. Com efeito, costumava-se adotar como ponto de partida da experiência intelectual de Canguilhem o ano de 1943, data de publicação da sua tese de doutoramento em medicina, Essai sur quelques problèmes concernant le normal et le pathologique (BRAUNSTEIN, 2000, p. 10). Todavia, hoje, se reconhece a indiscutível relevância filosófica da produção do primeiro Canguilhem (Ibidem, p. 10), isto é, dos textos, artigos e conferências, muitos dos quais assinados por pseudônimos ${ }^{4}$, que antecederam o aparecimento do Essai. O lançamento recente do primeiro tomo das Oeuvres Complètes de Canguilhem, que compreende os seus escritos filosóficos e políticos publicados originalmente entre 1926 e 1939, fornece ao

\footnotetext{
${ }^{2}$ Deve-se ressaltar que o trabalho do professor quebequense foi pioneiro na tentativa de organizar uma bibliografia completa da obra canguilhemeana. Tivemos a honra de conhecer pessoalmente o prof. Limoges durante nossa estada de pesquisa no CAPHÉS, rue d'Ulm, onde dividíamos a mesma bancada. Desta época, guardamos vivamente a lembrança do professor mergulhado nos manuscritos de Canguilhem, avaliando linha por linha, sempre à procura de novas referências. Trabalho sem fim, como ele mesmo dizia, pois a cada dia um novo texto se acrescentava à já extensa lista dos escritos do filósofo.

${ }^{3}$ Braustein admite que foi a leitura da bibliografia de Limoges que "avait aiguisé notre curiosité et nous avait conduit à rédiger un article sur 'Canguilhem avant Canguilhem"' (2011, p. 102, n. 1).

${ }^{4}$ Nos Libres propos, por exemplo, Canguilhem chegou a assinar vários textos sob o pseudônimo de C.-G. Bernard.
} 
pesquisador a possibilidade de conhecer o que pensava Canguilhem avant Canguilhem. Dentre eles, destacam-se o opúsculo Le fascisme et les paysants, publicado anonimamente em 1935, em Cahors, pelo Comitê de Vigilância dos Intelectuais Antifascistas, e o Traité de Logique et Morale, de 1939, o único livro anterior ao Essai, escrito por Canguilhem em conjunto com Camille Planet.

Além disso, o aprofundamento das pesquisas sobre Canguilhem tornou possível compreender melhor a trajetória intelectual do filósofo, desde os seus interesses de juventude até os escritos de maturidade, passando pelos seus inúmeros cursos - em liceus e universidades - assim como pelas suas conferências. O que se depreende deste material é, sobretudo, um traço distintivo do pensamento canguilhemeano: a estreita articulação entre a reflexão filosófica, a história da filosofia e as "matérias estranhas 5 ". Trata-se, nas palavras de Braunstein, de uma sorte de "curiosidade universal":

Esta curiosidade universal era já um traço marcante dos primeiros escritos de Canguilhem, como bem indica a simples enumeração dos títulos dos seus artigos: da questão da geração àquela da criação, passando pelas eleições inglesas ou por uma crise ministerial francesa, de uma peça de teatro de Sherriff a um exame dos assuntos do baccalauréat. Suas leituras e referências são também variadas: Alain, depois Bergson, sobretudo, mas também Descartes ou Leibniz, Balzac e Stendhal, Valéry ou Benda, Taine e Barrès, Keyserling ou Allendy, Lagneau, Hamelin ou Le Senne, Politzer ou Halbwachs, e ainda muitos outros (2011, p. 104).

A ampla variedade de assuntos abarcados pela reflexão canguilhemeana, somada ao seu intenso trabalho docente, talvez possam explicar a presença, muitas vezes latente, de Canguilhem nos debates maiores do pensamento francês do século XX. Eis o que observa um dos seus mais conhecidos alunos, Michel Foucault:

\begin{abstract}
Mas suprimam Canguilhem e vocês não compreenderão mais grande coisa de toda uma série de discussões que ocorreram entre os marxistas franceses; vocês não mais apreenderão o que há de específico em sociólogos como Bourdieu, Castel, Passeron, e que os marca tão intensamente no campo da sociologia; vocês negligenciarão todo um aspecto do trabalho teórico feito pelos psicanalistas, especialmente os lacanianos. Mais: em todo o debate de ideias que precedeu ou sucedeu o movimento de 1968, é fácil reencontrar o lugar daqueles que, direta ou indiretamente, haviam sido formados por Canguilhem (2008, p. 353).
\end{abstract}

\footnotetext{
${ }^{5}$ Nos anos 1940, Canguilhem afirmará: "La philosophie est une réflexion pour qui toute matière étrangère est bonne, et nous dirions volontiers pour qui toute bonne matiére doit être étrangère" (2007, p. 7). Para o filósofo francês, as ciências da vida ofereceram esse objeto estranho que alimentou sua experiência intelectual, como ele próprio reconhece: "nous attendions précisement de la médecine une introduction aux problèmes humains concrets" (Ibidem, p. 7).
} 
Avaliação exagerada ou diagnóstico preciso, fato é que as novas pesquisas sobre o filósofo redefiniram - e certamente continuarão a fazê-lo - a maneira como nós compreendemos o pensamento francês contemporâneo, a gênese dos seus problemas, as filiações teóricas que o perpassam e as rupturas e continuidades em relação às gerações anteriores, em particular no que diz respeito à herança filosófica legada por Cavaillès, Bachelard, Koyré, e pelo próprio Canguilhem.

É evidente que a republicação de antigos textos e conferências de Canguilhem, assim como a disponibilização da sua obra inédita, propiciará uma profunda reavaliação da maneira como até agora se interpretou a experiência filosófica canguilhemeana.

Com efeito, por muito tempo, foi quase exclusivamente a partir dos trabalhos sobre epistemologia e história das ciências que se procurou interpretar o pensamento canguilhemeano: tratava-se, então, de afirmar que Canguilhem era filósofo porque historiador das ciências, como se a história das ciências fosse para ele, "mais que um métier, uma segunda ou mesmo uma primeira natureza” (SÉRIS, 1993, p. 90-91). Em oposição a esta linha interpretativa, foi ganhando força a leitura que conferia maior centralidade para a filosofia biológica canguilhemeana, centrada na ideia de "normatividade vital". Em síntese, como escreve Roth, assumindo uma posição explicitamente contrária àquela que fora defendida por Séris, trata-se de afirmar que:

Longe de ser filósofo porque é historiador, nós pensamos, ao contrário, que Canguilhem era historiador das ciências porque ele era antes de tudo um filósofo; e é precisamente porque ele era filósofo, que Canguilhem se dirigiu à medicina - e à história das ciências, por conseguinte - para validar e retrabalhar, a partir de uma "matéria estranha", visões profundamente filosóficas. E desta experiência das "matérias estranha" nasceu o que se pode efetivamente chamar, com Gayon, de uma autêntica "'filosofia biológica', isto é, uma concepção geral da vida" (ROTH, 2010, p. 41, grifos nossos).

Não é preciso esconder que é no interior dessa última linha de comentadores que o presente trabalho se situa. Contudo, se admitimos isso de início é para anunciar uma diferença que faz dele um prolongamento mais do que uma repetição de pesquisas anteriores. Com efeito, todas essas, em maior ou menor grau, partilham da opinião de que a filosofia biológica de Canguilhem renova-se numa reflexão sobre o social e o político, desenvolvida, principalmente, entre o final dos anos 1950 e início de 1960, quando o autor publica as suas Nouvelles réflexions sur le normal et le pathologique. Tudo se passaria, então, como se apenas tardiamente Canguilhem tivesse se interessado pelas questões relativas ao social, 
permanecendo até essa época um filósofo estritamente concentrado nas problemáticas suscitadas pela reflexão médico-biológica.

Todavia, é numa direção contrária que a nossa pesquisa caminha. Nela pretendemos sustentar que a reflexão precoce sobre a questão da normalidade e da patologia sociais cumpre um papel fundamental no desenvolvimento do pensamento canguilhemeano sobre as ciências da vida e, por conseguinte, na elaboração da sua filosofia biológica. Desse modo, é preciso admitir que o social já figura como um campo indutor de problemas para Canguilhem desde os seus primeiros escritos, ao invés de se incorporar apenas tardiamente ao conjunto das "matérias estranhas" da reflexão filosófica canguilhemeana, como parece admitir a interpretação mais difundida sobre a relação entre as Nouvelles réflexions e o Essai.

Assim, esta pesquisa pretenderá realizar uma arqueologia das Nouvelles réflexions, procurando, nas publicações e textos inéditos de Canguilhem anteriores ao aparecimento desses novos ensaios, a gênese da reflexão canguilhemeana sobre o social. Buscaremos, também, mostrar que a incursão de Canguilhem nas ciências da vida é indissociável da maneira como o filósofo interpreta a sociologia durkheimeana e os problemas por ela legados acerca do uso das noções de patologia e saúde social. Finalmente, retornando às Nouvelles réflexions, nosso objetivo será extrair algumas consequências da ideia de vida como normatividade para a crítica de um certo modelo de compreensão da sociedade que opera, como em Durkheim e Comte, a partir da identificação entre o social e o orgânico.

Esse recurso a trabalhos inéditos ou secundários em relação aos textos canônicos de um autor desperta sempre a objeção daqueles que entendem que a pesquisa filosófica deve se concentrar principalmente nos momentos fundamentais de uma experiência filosófica, os quais constituiriam verdadeiramente a obra de um filósofo. Outrossim, no caso de Canguilhem, tal procedimento de investigação e análise da sua produção intelectual anterior à publicação do Essai se justifica por, ao menos, duas razões: em primeiro lugar, porque, como dissemos, a disponibilização dos Archives Canguilhem aos pesquisadores revelou que a tese de doutoramento em medicina, até então considerada amplamente o marco inicial da experiência filosófica do autor, é na verdade o ponto culminante de um percurso intelectual iniciado duas décadas antes. Nesse sentido, sentimo-nos amparados nesse nosso empreendimento pela interpretação de Braunstein, para quem os escritos do primeiro Canguilhem, isto é, aqueles anteriores à 1943, “permitem melhor compreender a evolução ulterior da obra, apreender, ao mesmo tempo, o que subsiste desse ponto de partida, mas também o que dele é definitivamente rejeitado por Canguilhem" (2000, p. 10); segundamente, 
o interesse teórico na investigação dos primeiros trabalhos canguilhemeanos é justificado pelo próprio autor que afirmava não se arrepender de nenhum "'dos seus escritos ou atos dos quais a coleção Libres propos conservará seus traços para a posteriridade', e acrescentava: 'tendo mudado sobre alguns pontos fundamentais, eu não experimento nenhum constrangimento ao ver relembrada as posições das quais parti"” (CANGUILHEM apud BRAUSTEIN, 2000, p. 10-11).

Cabe ainda ressaltar que, ao assumirmos a teoria social como ponto de partida da nossa investigação, não queremos recusar o fato de que o pensamento canguilhemeano sobre o vital se nutriu desde o início de uma reflexão sistemática sobre outros domínios de saber, como a psicologia, a história, a geografia humana. No entanto, a relevância da teoria social para esta pesquisa se justifica porque é sobretudo a racionalidade sociológica que Canguilhem considera tributária da tese fisiológica de Comte e Claude Bernard segundo a qual normal e patológico são conceitos objetivos, definíveis em termos de quantidade. De fato, no curso Les normes et le normal, que Canguilhem elabora paralelamente à redação do Essai, o filósofo afirma explicitamente sobre Durkheim que o que é preciso reprovar em sua sociologia é a adoção sem crítica dos “(...) conceitos fisiológicos clássicos, do fim do século XIX e desde Comte e Claude Bernard, conservando o problema do normal e do patológico", adimitindo “como um dogma que 'fisiológico equivale ao mesmo tempo à 'são' e à 'média"' (1942-1943, p. 50). A sequência do curso, que corresponderá justamente às duas partes do Essai, dedica-se à análise crítica desse dogma a partir da qual Canguilhem elaborará a sua própria filosofia da vida como potência normativa.

Além disso, o privilégio que nossa pesquisa concede à reflexão canguilhemeana sobre o social é motivado pelo atual debate filosófico acerca do recurso a categorias biológicas, como normal e patológico, para a crítica social. Parece-nos que esse debate e os impasses sociológicos e médicos que ele suscita podem se beneficiar de uma análise mais sistemática das relações entre a filosofia da vida de Canguilhem e o seu pensamento sobre a sociedade.

A presente dissertação se divide em três partes. A primeira delas, intitulada A gênese de um dogma médico-sociológico, é composta de dois capítulos. No primeiro capítulo, tratase, inicialmente, de situar a reflexão canguilhemeana sobre a sociologia no contexto de um diagnóstico de época mais amplo que identificava, na constituição das ciências humanas, a 
exigência de submissão dos fenômenos psicológicos, históricos ou sociais à forma geral da quantidade, possibilitando, assim. a hegemonização dos métodos científicos de cálculo, previsão e controle. Depois, seguiremos a análise canguilhemeana da sociologia de Durkheim a fim de mostrar que, nela, tal submissão foi propiciada pela importação da teoria médica da identificação entre generalidade e normalidade, com a consequente redução das patologias a uma variação quantitativa do normal. Portanto, sob as noções durkheimeanas de normalidade e doença sociais, o que Canguilhem revelará é a transformação da racionalidade médicobiológica num modelo hegemônico de cientificidade, que se caracterizaria, sobretudo, pela redução da diversidade qualitativa dos fenômenos a variações quantitativas. Além disso, mostraremos que, segundo Canguilhem, a definição da normalidade social em termos puramente quantitativos era insuficiente para Durkheim explicar a regularidade observada nos fenômenos sociais. Com isso, seremos levados a descobrir uma filosofia realista do social, ou uma ontologia social, como fundamento da normalidade de fato. Porém, essa ontologia social, ao afirmar que as normas de regulação social e os fins sociais são fatos dados na sociedade, tende a confundir social com o organismo biológico, que é o único a portar em si, dirá Canguilhem, suas próprias normas de vida.

No capítulo segundo dessa primeira parte, exporemos a genealogia canguilhemeana da teoria médico-biológica da identificação entre generalidade e normalidade, que o filósofo encontrara em operação no método sociológico de Durkheim. Para tanto, seguiremos, sobretudo, o curso Les normes et le normal (1942-1943) e a primeira parte do Essai, nos quais Canguilhem atribui à biologia positiva de Comte e à fisiologia de Claude Bernard a responsabilidade por terem transformado tal teoria numa espécie de dogma cientificamente garantido, que se disseminou para outros domínios do saber como modelo geral de inteligibilidade dos fenômenos.

A segunda parte desta dissertação dedica-se a apresentar a filosofia canguilhemeana da vida desde as discussões do jovem canguilhem sobre a criação técnica até a formulação do conceito de normatividade vital, na segundo parte do Essai e nos cursos contemporâneos à redação da tese. Nesse momento, importa-nos apresentar os conceitos e consequências fundamentais da filosofia canguilhemeana a fim de tornar claro de que maneira ela oferece uma perspectiva crítica ao dogma médico de Comte e Claude Bernard assimilado por Durkheim. Essa crítica se formulará, como veremos, pela insistência na irredutibilidade do normal ao patológico, cuja distinção se estabelece não objetivamente, em termos quantitativos, mas subjetivamente, na oposição entre valores vitais positivos e negativos. Daí 
porque, como Canguilhem afirmará, não é possível reduzir o normal à média ou à generalidade, posto que antes de ser objetivamente definível, ele é subjetivamente experimentado como portador de uma qualidade propulsiva, criadora de novas formas de relação do organismo ao meio. Por outro lado, não é também possível identificar imediatamente a anomalia com a patologia, posto que esse desvio talvez possua em certos meios um valor normativo. Pretendemos também, nessa segunda parte, propor que a concepção canguilhemeana de vida como normatividade deve ser compreendida como um vitalismo negativo, na medida em que a saúde, definida como capacidade de instituir novas normas num determinado meio, é antes potência de indeterminação de formas estabilizadas de vida.

Finalmente, na terceira parte desta pesquisa, pretendemos extrair algumas consequências do vitalismo negativo de Canguilhem para a crítica de um certo modelo de inteligibilidade do social. Veremos que esse modelo é aquele que identifica o social ao orgânico concebendo o primeiro como uma totalidade funcional mantida por um princípio interno de regulação. As sociedades seriam, portanto, portadoras dos fins supremos segundo os quais se orientaram os seus diversos componentes. O que retorna, assim, ao campo da reflexão canguilhemeana é a ontologia social de Durkheim, para qual a sociedade deve ser entendida como possuindo os mesmos mecanismos regulativos que existem nos organismos, o que já estava anunciado na leitura que Canguilhem faz do sociólogo no seu curso de 1947: "a noção [de sociedade] é aquela de um ser transcendente ao indivíduo cuja realidade seja capaz de portar o valor supremo, aquele que serve para regular e reger definitivamente toda a atividade do indivíduo" (CANGUILHEM, 1947, p. 1, negritos nossos). Mas não é somente Durkheim que assimila a sociedade ao organismo. Outro autor privilegiado pela reflexão canguilhemeana procede exatamente da mesma maneira: trata-se de Comte. Na interpretação de Canguilhem, a política positiva é concebida por Comte como "uma função geral de regulação social" (1972, p. 712). Dizer que a sociedade possui valores que regulam e regem toda a atividade individual é afirmar que ela cria suas próprias normas de funcionamento, o que é precisamente a capacidade definidora do orgânico para Canguilhem. 


\section{Parte I - Um conceito de saúde: norma, normal e medida}

\section{A determinação do fato: quantificação e normalidade nas ciências humanas}

A crítica canguilhemeana à teoria social, que se concentrará, como veremos adiante, na sociologia de Durkheim, inscreve-se num projeto filosófico mais amplo de afirmação da irredutibilidade do espírito, enquanto criador do dado, ao próprio dado, do valor subjetivo ao fato objetivo, definível em termos quantitativos (CANGUILHEM, 2011, p. 793). Canguilhem mostrará que o pensamento sociológico durkheimeano partilha com outros setores das ciências humanas - tais como a psicologia, a história e a política - de um modelo hegemônico de racionalidade científica para o qual a inteligibilidade dos fenômenos depende da sua redução a coisas ou fatos, com a consequente eliminação do que neles pode se referir a valores subjetivamente fundados.

Tal projeto filosófico de critica da hegemonia do dado sobre o espírito começa tomar forma nos escritos de Canguilhem já em 1927, quando a oposição entre fato e valor se coloca pela primeira vez a propósito do apoio do filósofo ao protesto estudantil contra a chamada lei Paul-Boncour, que previa diversas medidas de militarização da França, dentre as quais, "na ordem intelectual, uma orientação dos recursos intelectuais do país no sentido da defesa nacional" (Ibidem, p. 164, n. 1). Que a situação histórica da Europa entreguerras impusesse como um fato o incremento do poder bélico dos países, isto não era suficiente para justificar o apoio àquela lei, pois, observa Canguilhem, “o fato não tem ele mesmo valor. E mesmo, do momento em que ele existe como fato, é que ele porta nele suas condições. As condições, quem as conhece, as muda. Também o fato traduz não o que se faz, mas o que não se faz" (Ibidem, p. 167).

Canguilhem era cônscio de que o recurso ao fato constituía uma das maneiras pelas quais a ideologia operava a naturalização dos processos políticos, abstraindo-os das condições sócio-históricas determinadas das quais dependiam. Com efeito, defender que algo existe como um fato significa assumir que sua natureza não se deixa determinar pela maneira como os sujeitos se relacionam com ele. Assim, o que Canguilhem questiona é a possibilidade de se compreender os acontecimentos históricos sob o modelo de inteligibilidade dos fenômenos do 
mundo físico, o que se daria pela afirmação de que ambos se submeteriam a um sistema próprio e determinado de leis, independe das decisões subjetivas.

Resistir aos fatos em nome da liberdade criadora do sujeito se tornou a grande divisa canguilhemeana na sua polêmica contra os que insistiam na vacuidade de toda ação que pretendesse se opor à necessidade dos acontecimentos históricos, em particular à guerra. Em Deux explications philosophiques de la guerre, publicado em fevereiro de 1931, Canguilhem contrasta duas explicações sobre o primeiro grande conflito bélico mundial: a de Alain e a de Quinton. Para o primeiro, "a guerra não é um fato da natureza, determinado como a cor da nossa pele. (...) Um tal fato, como sem dúvida todo outro fato da ordem humana, e, por exemplo, a injustiça social, é apenas a tradução evidente do que nós não fazemos" (Ibidem, p. 339). Em explícita oposição às teses de Alain, aparece Quinton, cuja ideia essencial é a de que "a guerra é um fato da natureza; ela é o estado natural dos machos" (Ibidem, p. 339). Fazendo apelo à teoria darwiniana da seleção natural, Quinton pensava a guerra como o correspondente na ordem humana da luta entre os animais machos pela conquista da fêmea e pela reprodução da espécie ${ }^{6}$.

Mas o apelo ao fato como solo objetivo de inteligibilidade dos fenômenos não constitui um recurso exclusivo dos discursos políticos sobre a guerra. Há ainda três outros campos em que Canguilhem denuncia a redução ao fato: a História, a Psicologia e, finalmente, a Sociologia (Ibidem, p. 119).

Quanto à História, a crítica canguilhemeana se endereçará, sobretudo, à ideia de fato histórico. Com efeito, para o jovem Canguilhem, resume Braunstein, "o historiador, do mesmo modo como mais tarde será o caso do historiador das ciências, não deveria aceitar como 'dados' pretensos 'fatos históricos'. Cabe a ele escolher e estabelecer os fatos" (ibidem, p. 121). A partir do século XIX, observa Canguilhem, a História procurou se estabelecer como ciência positiva, de tal modo que "o historiador, como a testemunha, pensa poder dizer 'toda a verdade, nada além da Verdade"' (Ibidem, p. 765). É dessa maneira que Canguilhem interpreta a obra de Camille Bloch, Les causes de la guerre mondiale, na qual a leitura canguilhemeana denuncia a promessa de fornecer, pela bagatela de 12 francos, "' $\mathrm{A}$ VERDADE HISTÓRICA', simples relato do que realmente se passou em julho de 1914" (Ibidem, p. 461). Bloch, como historiador, seria portanto aquele que forneceria a versão final

\footnotetext{
6 Vale destacar que a tentativa de ancorar um diagnóstico social sobre alguns fatos supostamente bem estabelecidos pela biologia faz de Quinton uma importante referência para Canguilhem, que, no seu curso Philosophie de la guerre et de la paix, de 1930-1931, observará: “o transporte das ideias biológicas na ordem do social foi recentemente renovada pelo livro de R. Quinton: Maximes sur la guerre” (Ibidem, p. 108, n. 4).
} 
dos acontecimentos passados, a narrativa objetiva da História, segundo a qual a guerra seria uma fatalidade inelutável. Uma outra concepção do trabalho de historiador, Canguilhem a encontrará no livro 1914 - Le problème des origines de la guerre, de Jules Isaac, cujo autor, escreve o filósofo:

(...) confere ao espírito o serviço do inapreciável, aquele mesmo que deve - em razão da matéria do seu estudo - conferir ao historiador, ele coloca na presença de um problema sempre aberto. Há problema lá onde a necessidade única cessa de ser a lei. Desde que o pensamento humano venceu o ideal da fatal chegada das coisas, desde que o acontecimento retomou sua relação com a resolução livre que lhe dá sentido e peso, então parece que a falta consiste igualmente em acreditar que o outro está fadado ao mal e em acreditar que si mesmo está fadado ao bem (Ibidem, p. 465).

Abrupto deslocamento da crítica à historiografia para a reflexão sobre a moral. O que justificaria a sua aproximação? A cegueira de Bloch e a astúcia de Isaac para perceber que os acontecimentos não podem ser desvinculados das escolhas que os motivaram, das decisões subjetivas que os trouxeram à luz. "Comumente, a história é estimada por dar às nações uma boa consciência” (Ibidem, p. 465), como se aquelas fossem apenas marionetes movidas pela fatalidade histórica, face a qual nenhum governo, nenhum exército, teria com que se preocupar: "não tivemos culpa, foi assim porque era necessário que assim fosse", pensa tranquilo no seu gabinete o ditador sanguinário, o especulador famigerado, o fanático religioso.

No que diz respeito à psicologia, deve-se destacar, de inicio, que a crítica canguilhemeana ao fato psicológico é herdeira da filosofia de Alain. Em Mars ou la guerre jugée, Alain designa os psicólogos como "adoradores do fato, neles mesmos e ao redor deles" (1960, p. 645). Por conceberem o psiquismo humano como uma coisa, um dado, que a psicologia precisa descrever o funcionamento necessário segundo leis, esses psicólogos, "pensadores covardes" (ibidem, p. 644), encontram na afirmação do fato a justificativa da sua submissão não apenas ao que é preciso sofrer, como a chuva ou a neve, mas também ao que é necessário querer para existir, como a justiça e a paz (ibidem, p. 645). É no interior dessa tradição crítica que é preciso compreender a elogiosa resenha de Canguilhem ao panfleto de Politzer contra Bergson, intitulado La fin d'une parade philosophique: le bergsonisme. A leitura canguilhemeana endossa a crítica de Politzer segundo a qual Bergson teria fracassado na sua procura dos dados imediatos da consciência. Replicando Politzer, Canguilhem afirma que tanto a filosofia da duração quanto a psicologia clássica partem da realidade do fato 


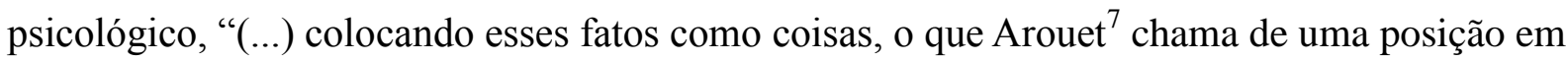
terceira pessoa" (CANGUILHEM, 2011, p. 223). Mas a crítica à psicologia experimental não se dá apenas neste compte-rendu; ela aparece em outros escritos de juventude ${ }^{8}$, em que se replica o diagnóstico de que, "fazendo do espírito um universo à parte, separável e observável com o uso de aparelhos, [a psicologia] faz do espírito uma coisa, isto é, enterra-o como espírito" (Ibidem, p. 224).

Eis o que reencontraremos em 1939, no Traité de logique et de morale. Trata-se aí de reafirmar novamente a impossibilidade de uma "ciência" psicológica, de cuja fundação definitiva se orgulhavam a psicofísica, a psicofisiologia e a chamada psicologia da reação ou do comportamento.

Tanto a psícofísica quanto a psicofisiologia tem em comum, segundo Canguilhem, a pretensão de explicar os fenômenos psíquicos a partir das suas condições objetivas - seja o estímulo físico, no primeiro caso, seja o substrato fisiológico, no segundo. Além disso, elas supõem existir entre o estímulo e a reação psíquica uma correspondência capaz de ser expressa na forma de uma lei. De tal suposição, Canguilhem extrai ainda duas consequências maiores: primeiramente, se há correspondência ponto a ponto entre o mental (condicionado) e o físico (condição), então é preciso admitir que o primeiro seria composto por um conjunto de elementos isoláveis, interpretáveis, portanto, pelo mesmo tipo de análise que decompõe os corpos em relações fixas; em segundo lugar, afirmar a correspondência entre o mental e o orgânico seria reduzir o primeiro ao segundo, esvaziando-o da dimensão propriamente subjetiva que o caracteriza como psíquico. Assim, conclui o filósofo,

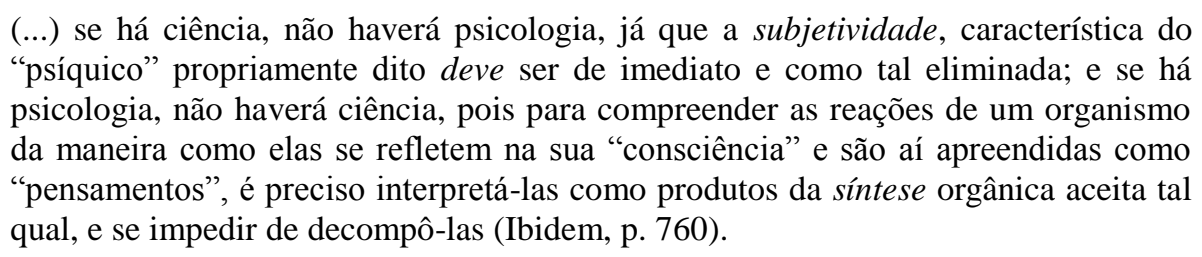

A oposição que Canguilhem aí estabelece entre ciência e psicologia replica a oposição entre a objetividade analítica e a subjetividade sintética. O psíquico, então, é aquilo cuja

\footnotetext{
${ }^{7}$ François Arouet, o verdadeiro nome de Voltaire, foi utilizado por Georges Politzer como seu pseudônimo na assinatura do panfleto anti-bergsoniano.

${ }^{8}$ Vale destacar aqui as ironias dirigidas à "Pawlow", em Foch et Clemenceau ou la mort avec Phases, assim como em outros textos dos Libres propos, assinados por Michel Alexandre ou Jean Laubier. Para uma análise mais detalhada da crítica canguilhemeana à psicologia, ver BRAUNSTEIN, J.-F. La critique canguilhemienne de la psychologie', Bulletin de psychologie, v. 52, n. 2, mars-avril 1999, p. 181-190.
} 
decomposição em elementos mínimos capazes de se submeterem à medição não é possível. Nesse sentido, completa o filósofo:

\begin{abstract}
Essas observações vem notar, em suma, que a interpretação psicológica da vida, sendo uma interpretação antes de tudo sintética, exclui a ideia mesma de Medida, que é forçosamente aquela de uma Divisão em partes idênticas: o psíquico é, por essência, o que é inapto à medida, e é então uma proposição contraditória querer apreender o psíquico como tal, procurando medi-lo (Ibidem, p. 762).
\end{abstract}

Porém, é importante destacar nessas considerações um diagnóstico mais geral sobre a racionalidade científica moderna. Para Canguilhem, a ciência não é capaz de apreender o que diz respeito ao pensamento humano sem decompor totalidades dotadas de sentido em unidades elementares e calculáveis. Em outras palavras, Canguilhem reconhece que a transformação dos fenômenos humanos, mentais ou sociais, em objetos de ciências específicas exige como condição “(...) submeter a própria vida espiritual ao tratamento, aos métodos, que a Física aplica ao estudo das coisas materiais, e então tornar a vida inteligível e explicável da mesma forma que as coisas são" (2011, p. 641). Tais métodos, continua Canguilhem, se resumem à aplicação de “(...) uma forma métrica; a ordem da unificação da ciência deve permanecer aquela da unificação pela Quantidade" (Ibidem, p. 760, grifos nossos).

A quantidade unifica porque, a partir dela, a ciência se torna capaz de reduzir a diversidade fenomenal a variações numéricas de elementos fundamentais atomizados. No caso da Física, essa redução alcança os mínimos componentes da matéria como essência última de toda natureza, cuja multiplicidade de fenômenos resulta da reunião ou separação daqueles componentes segundo certas leis invariáveis. Por isso que a imposição da forma métrica à natureza “(...) permite distinguir os objetos somente pelo mais e menos, e não como tal e tal outro" (2011, p. 658); permite, enfim, reduzir o fenômeno, por análise, a um conjunto de elementos idênticos e homogêneos entre si, cuja relação numérica seria a verdadeira expressão objetiva da realidade exterior:

\footnotetext{
Importa, com efeito, notar agora a equivalência lógica das duas últimas expressões [medida e objetividade]: supor uma Natureza objetivamente real ou uma Quantidade possível como forma desta Natureza, isso implica sempre em fazer de uma coisa um todo definido de partes distintas e impenetráveis, que se determinam então ou se limitam da mesma maneira como muitas coisas entre si. A referência do julgamento a um mundo exterior é a Medida; quer se a chame de Realidade ou Quantidade, a forma consciente da crença teórica fundamental continua a mesma (Ibidem, p. 659).
} 
Dizer que a medida se tornou a referência do julgamento é afirmar que aquilo a que esse se refere como norma de apreciação da experiência é uma quantidade determinada, um certo número estabelecido pelo cálculo. Se a norma é uma medida, normal passa a designar então tudo quanto é conforme a essa medida. Mas o que fazer então com a experiência humana que parece atribuir qualidades diversas, valores opostos, àquilo que para a ciência é apenas quantidade? Ela deve ser combatida como uma ilusão que se opõe ao conhecimento verdadeiro que é conhecimento das quantidades. Daí a conclusão que se impõe a Canguilhem:

\begin{abstract}
No debate pendente entre a Qualidade e a Quantidade, o papel formal da ciência é de presumir, inicialmente, de demonstrar, em seguida, a supremacia da Quantidade; a experiência ela mesma é neutra, a função 'material' da Qualidade é aquela de um adversário: é aquele de uma Ilusão se opondo às exigências da Verdade (Ibidem, p. $660)$.
\end{abstract}

Sob a diversidade qualitativa da experiência, a ciência se esforçaria para reencontrar o real ou a quantidade como sua essência última. Expurgado tudo aquilo que diz respeito às ilusões subjetivas pela submissão à forma geral da quantidade, a realidade pode enfim se revelar na sua absoluta necessidade como "o que não pode não ser" (Ibidem, p. 646), ou seja, como um fato, cuja necessidade elimina a ideia de que sua existência é contraditória, alterável, não-idêntica.

Como Canguilhem mostrou, a constituição da psicologia como ciência exigiu a anulação da subjetividade pela sua decomposição num conjunto de elementos atomizados e mensuráveis. Mas o filósofo observa que o mesmo ocorreu no âmbito da teoria social. Aí, o estabelecimento de uma ciência dos fenômenos sociais, a sociologia, implicou na adoção do método analítico para a explicação daqueles fenômenos, reduzindo-os a fatos desprovidos de qualquer valor ou sentido subjetivos:

De fato, a considerar o uso normal que pode ser feito dos procedimentos analíticos prescritos por Comte e por Durkheim, aperceber-se-á novamente que esses procedimentos valem, teoricamente, para a pesquisa de leis na medida em que, concernindo a conjuntos numeráveis de objetos, eles têm sucesso ao excluir, dos enunciados obtidos, a apreciação que pode ser feita deles subjetivamente; é o valor das coisas para os homens, isto é, o pensamento que é normalmente eliminado, e é uma realidade presumivelmente válida em si que a análise substitui a este valor (Ibidem, p. 774).

Esse diagnóstico que o Traité de logique et de morale endereça à racionalidade quantificadora incorporada pela sociologia nascente será desenvolvido posteriormente em 
dois cursos de Canguilhem, Les normes et le normal, de 1942-1943, e Durkheim, "Les règles de la méthode sociologique", de 1947.

Aqui, um novo problema historiográfico parece se colocar a nossa pesquisa: como justificar a remissão a cursos jamais publicados no quadro de uma pesquisa que pretende compreender a formação da reflexão canguilhemeana sobre a vida? De fato, interpretar aspectos de uma obra a partir de cursos parece ser uma estratégia questionável, pois um curso é geralmente um espaço de experimentação, de ensaio intelectual, em que as ideias não estão consolidadas como nos textos publicados. Além disso, no que concerne a Canguilhem, muitos dos seus cursos se resumem a um conjunto fragmentado de apontamentos, sem o trabalho formal de organização pelo qual tanto preza o filósofo nos seus livros e artigos. Porém, a recuperação daqueles dois cursos inéditos de Canguilhem no interior desta pesquisa segue uma estratégia diversa: não se trata de explicar a partir deles total ou parcialmente a obra, mas de desenvolver questões e ideias que aparecem apenas em estado embrionário nos textos publicados, enquanto estão mais elaboradas nos cursos. Outrossim, a questão que ora reclama nossa remissão aos citados cursos, a saber, a crítica canguilhemeana à assimilação pela sociologia de um modelo de racionalidade que opera por redução das qualidades a quantidades, recebe uma formulação bastante precisa em tais cursos, reaparecendo quase que sem alterações em cursos ulteriores. Finalmente, os dois cursos a que fizemos alusão se distinguem por apresentarem uma redação mais elaborada, o que se verifica não apenas pela sua extensão como também pelo fato do autor ter retrabalho o texto original em outras versões.

Tanto em Les normes et le normal quanto em Durkheim, "Les règles de la méthode sociologique" o diagnóstico da importação para a sociologia de procedimentos analíticos de quantificação dos fenômenos, com a consequente eliminação da apreciação subjetiva do valor desses fenômenos, concentra-se na análise do método sociológico de Durkheim. A escolha desse autor não é aleatória. Ela se justifica porque a teoria social durkheimeana não apenas submete os fenômenos sociais a um padrão geral de quantificação oriundo do cálculo estatístico como também identifica o valor médio obtido dessa maneira à noção médicobiológica de saúde, em referência à qual o sociólogo seria capaz de diagnosticar os casos estatisticamente desviantes ou patológicos. Com isso, a sociologia durkheimeana revela para Canguilhem o papel fundamental desempenhado pelas ciências da vida como fornecedoras de um modelo geral de cientificidade para a constituição de um conhecimento sobre o social. Nem a Psicologia, nem a História, nem os discursos políticos sobre a guerra apresentam de 
forma tão evidente quanto a sociologia a maneira como a imposição de um padrão geral de inteligibilidade dos fenômenos dependente da sua quantificação era tributário do discurso médico-biológico, em particular da biologia positiva de Comte e da fisiologia de Claude Bernard.

Consolidar a apropriação desse modelo médico de distinção entre o normal e o patológico no âmago da sociologia durkheimeana constitui o objetivo do terceiro capítulo de Les règles, intitulado Le normal et le pathologique. Não é por acaso, portanto, que sobre ele se concentra a análise canguilhemeana dessa obra.

\section{A concepção quantitativa de saúde e patologia sociais, em Les règles de la méthode sociologique}

As categorias de saúde e patologia sociais atravessam de ponta a ponta a obra durkheimeana. Desde De la division du travail social (1893) até Les formes élémentaires de la vie religieuse (1912), passando obviamente por Le suicide (1897), elas organizam de maneira ora mais ora menos explícita a classificação dos fenômenos sociais estudados pelo sociólogo francês ${ }^{9}$. Nesse sentido, é bem preciso admitir com Renault que "Durkheim, mais do que qualquer outro, elevou o tema da patologia social à dignidade de um conceito sociológico com função arquitetônica" (2008, p. 249). Nesta seção, pretendemos compreender a leitura canguilhemeana do terceiro capítulo de Les règles, no qual se trata de fornecer uma solução para a pergunta: como é possível ao cientista distinguir objetivamente os fatos sociais normais dos patológicos?

De início, Durkheim aponta a insuficiência dos critérios usuais para a determinação dos fenômenos patológicos que ou insistem sobre a relação entre doença e dor ou defendem a vinculação entre patologia e desadaptação. O teórico afirma que a correlação entre dor ou sofrimento - que o texto parece tomar como sinônimos - e doença é falha em "constância e precisão" (1987, p. 50), pois existem fenômenos fisiológicos, como o parto ou a fome, que são acompanhados de sofrimento, enquanto que certas doenças fazem o enfermo experimentar algum prazer em situações extremamente dolorosas para o indivíduo são.

\footnotetext{
${ }^{9}$ Nesse sentido, é fundamental lembrarmos que, desde De la division du travail social, Durkheim utiliza a categoria de anomia como uma espécie maior de patologia social decorrente do déficit de regulação da divisão do trabalho.
} 
Relaciona-se também a saúde a um estado de optimum das forças vitais, no qual o organismo conseguiria se adaptar da maneira mais bem sucedida ao seu meio. Porém, não obstante as várias formulações que se pode dar à definição de sucesso diante do meio, essa concepção também encontra problemas. Se se entende que o sucesso adaptativo é medido pela taxa mais elevada de sobrevivência, então se é objetado pelos dados que revelam que certos fenômenos fisiológicos normais, como a velhice, a infância ou a menstruação, tornam os indivíduos mais susceptíveis de se contaminarem ou desenvolverem algum distúrbio letal; por outro lado, algumas doenças de baixa gravidade não afetam as bases vitais do organismo tanto quanto outras mais graves, desde que tratadas. Além disso, certas doenças, como a varíola, podem ser inoculadas na forma de vacina, contribuindo assim para a maximização das possibilidades de sobrevivência do organismo.

Finalmente, ainda no que diz respeito aos problemas que suscitam essa concepção da saúde atrelada ao índice de sobrevivência, questões metodológicas a tornam problemática seja para a biologia seja, com mais forte razão, para a sociologia. O problema central que se coloca é o de saber em que se pode reconhecer um fenômeno patológico. A resposta mais óbvia, que está vinculada a não importa qual concepção de sucesso adaptativo, defende que todo estado anormal se denuncia na perturbação que ele provoca no desenvolvimento normal das funções. Porém, objeta Durkheim, “esta prova já considera o problema como resolvido; pois ela não é possível senão estando previamente determinado em que consiste o estado normal e, por conseguinte, desde que se sabe o sinal que o torna reconhecível” (Ibidem, p 54). Em outras palavras, para se reconhecer o patológico em termos de perturbação das funções normais é preciso saber de antemão qual é o estado normal do organismo ou da sociedade. Toda a questão consistindo agora em estabelecer uma maneira objetiva de determinar o estado normal, posto que o critério do sucesso adaptativo já se mostrou problemático pois não apenas os fenômenos normais podem ser prejudiciais para a sobrevivência de um organismo como certas patologias contribuem para a adaptação do vivente.

É importante sublinhar aqui que, para Durkheim, o conhecimento do normal social antecede e é condição de possibilidade para o diagnóstico das patologias sociais. Nesse sentido, Durkheim partilha com Comte e com a tradição biológica positivista, que examinaremos no próximo capítulo, da tese segundo a qual a determinação da normalidade é cronológica e logicamente anterior à identificação das doenças. Sobre isso, Renault observa que Les règles "permitem apreender a especificidade (comteana) da concepção durkheimeana 
da patologia social (...)" (2008, p. 251, grifos nossos), na medida em que tanto em Comte quanto em Durkheim, para além da continuidade não problemática entre biologia e sociologia, afirma-se uma “(...) dependência da dinâmica social e da patologia social em relação à fisiologia social” (Ibidem, p. 248). Porém, no Essai, Canguilhem defenderá que a afirmação dessa dependência deve ser compreendida no quadro mais amplo de uma medicina que confere à clínica e à subjetividade doente um papel apenas secundário em relação ao conhecimento objetivo conquistado pela ciência. Tudo se passa, portanto, como se o normal fosse um conceito empírico, objetivo, passível de ser determinado por processos de mensuração, de modo que qualquer referência a um valor subjetivo de saúde é desnecessária.

Assim, a adoção pela sociologia de Durkheim dos conceitos fisiológicos de normal e patológico implicou na assimilação da tese da dependência do patológico em relação ao conhecimento do normal. Por isso que o sociólogo se esforçará para encontrar um critério objetivo de demarcação entre fenômenos normais e patológicos que não faça apelo a qualquer tipo de pré-conceitos sobre as forças ou potências do vital, o que traria de volta um fundamento subjetivo para a distinção entre a saúde e a doença sociais, como aquele baseado na ideia de sofrimento ou de sucesso adaptativo. Tal critério objetivo é, para Durkheim, "algum sinal exterior, imediatamente perceptível, mas objetivo, que nos permita distinguir uma ou outra dessas duas ordens de fenômenos" (1987, p. 55). A partir desse método semiológico $^{10}$, o sociólogo distinguirá duas modalidades de fatos: uns são gerais em toda a extensão da espécie, podendo ser encontrados, senão em todos os indivíduos, ao menos na maior parte deles, com variações mínimas e circunscritas a limites bem definidos; os outros são excepcionais ou, como diz o sociólogo, "eles são uma exceção no tempo como no espaço" (ibidem, p. 55). Ao primeiro tipo de fenômenos, Durkheim chama de normais, enquanto os segundos são designados como anormais ou patológicos.

Da reunião de todas as características normais, com a sua forma mais frequente encontrada numa espécie, teríamos o "tipo médio" ou "tipo genérico, que Durkheim assim

\footnotetext{
${ }^{10}$ Esse método é considerado por Durkheim o segundo corolário da primeira e mais fundamental regra do método sociológico: “(...) considerar os fatos sociais como coisas" (1987, p. 15). Ora, para o sociólogo francês, a coisa se opõe à ideia como aquilo que não é imediatamente penetrável pela inteligência, aquilo "(...) que o espírito não pode compreender senão com a condição de sair de si, pela via de observações e de experimentações, passando progressivamente das características mais exteriores e mais imediatamente acessíveis, para as menos visíveis e mais imediatamente profundas" (Ibidem, p. XII-XIII). Disso resulta o segundo corolário do método: "somente tomar como objeto de pesquisa um grupo previamente definido por algumas características exteriores que lhe são comuns e compreender na mesma pesquisa todas aqueles que respondem a essa definição" (Ibidem, p. 35).
} 
define":

Se se convém nomear tipo médio o ser esquemático que se constituiria juntando, em um mesmo todo, uma espécie de individualidade abstrata, as características mais frequentes na espécie com as suas formas mais frequentes, poder-se-á dizer que o tipo normal se confunde com o tipo médio, e que todo desvio em relação a este patamar de saúde é um fenômeno mórbido (ibidem, p. 56).

Nesse trecho, Canguilhem destaca a identificação entre as noções de média, entendida em termos de frequência estatística ${ }^{11}$, normal e saúde. O fisiologista estuda o tipo geral porque ele fornece a norma da saúde, do mesmo modo, em sociologia, "nós chamaremos normais os fatos que apresentam as formas mais gerais e nós daremos aos outros o nome de mórbidos ou patológicos" (Ibidem, p. 39). Não é por outra razão que, para se qualificar um fenômeno como patológico, é necessário, segundo Durkheim, compará-lo ao tipo normal constituído a partir da abstração dos caracteres médios de uma espécie. Como resume Renault:

Em Les Règles de la méthode, o conceito de patologia social é formulado no contexto de uma discussão abstrata sobre a relação da saúde, da média e da normalidade: o patológico é definido como um desvio em relação às normas que se exprimem nas médias sociais características do estado de desenvolvimento específico de um tipo de organismo social particular (2008, p. 251).

Julgar um desvio social como uma patologia é admitir que a não conformação a uma medida leva necessariamente à produção de um fenômeno com valor negativo que demanda correção. Com isso, o julgamento do valor normal ou patológico de um fenômeno subordina-

\footnotetext{
${ }^{11}$ O recurso ao cálculo estatístico é sugerido por Durkheim como um utensílio metodológico indispensável para operar a distinção entre os fatos sociais e as suas formas individuais de expressão. Assim, certas correntes de opinião, que impelem os indivíduos de uma determinada sociedade, segundo as épocas e as regiões, a agirem de um determinado modo - contraindo matrimônio, suicidando-se etc -, podem parecer indissociáveis das formas que assumem nos casos individuais, mas, afirma Durkheim: "a estatística oferece-nos o meio de isolá-las. São, com efeito, expressas, - e não sem exatidão, - pelas taxas de nascimento, de casamento, suicídios, isto é, pelo algarismo que se obtém dividindo-se o total médio anual dos casamentos, dos nascimentos, das mortes voluntárias, pelo total médio dos homens em idade de casar, de procriar, de suicidar. Como cada um desses números compreende todos os casos particulares indistintamente, as circunstâncias individuais que podem desempenhar qualquer papel na produção do fenômeno se neutralizam mutuamente e, por conseguinte, não contribuem para determiná-lo. O que cada número exprime é um certo estado da alma coletiva” (1987, p. 9-10).
} 
se, no pensamento sociológico durkheimeano, a um julgamento empírico: a relação desse fenômeno com uma medida tomada como norma. Reduzido a uma quantidade, o estado normal deixa de significar a qualidade que uma subjetividade vivente atribui a um fenômeno ou situação para se converter num fato passível de medição. Assim se esclarece o diagnóstico de Canguilhem no Traité, segundo o qual, na sociologia durkheimeana, “(...) é o valor das coisas para os homens, isto é, o pensamento que é normalmente eliminado, e é uma realidade presumivelmente válida em si que a análise substitui a esse valor" (CANGUILHEM, 2011, p. 774).

Contudo, se, por um lado, essa substituição autoriza Durkheim a afirmar a objetividade do diagnóstico das patologias sociais, por outro lado ela suporta uma concepção conservadora de sociedade, na medida em que o sociólogo francês não é capaz de pensar as anomalias como portadoras de uma normalidade social em via de se estabelecer. Dissociar, portanto, o anômalo do patológico será uma das exigências necessárias para se colocar em questão a ideia durkheimeana de que as normas sociais existentes, reveladas pelo cálculo das médias, são fatos submetidos a leis invariáveis. Tal dissociação, como veremos na segunda parte deste trabalho, será uma das contribuições maiores da filosofia canguilhemeana da vida, posto que através dela o filósofo recuperará a dimensão irredutivelmente subjetiva do valor das normas biológicas, impossíveis de serem totalmente identificadas a uma medida qualquer: "mas a diversidade não é doença. O anômalo não é o patológico. Patológico implica pathos, sentimento direto e concreto de sofrimento e de impotência, sentimento de vida contrariada" (CANGUILHEM, 2007, p. 85).

Antes, porém, de darmos esse passo em direção à filosofia da vida de Canguilhem, convém insistirmos mais sobre a identificação durkheimeana entre o normal e o tipo médio. Para isso, não é sem interesse seguirmos a trilha de Canguilhem, retornando ao ponto que o filósofo reconhece como a origem daquela identificação (CANGUILHEM, 1942-1943, p. 41): a teoria do homem médio, de Quêtelet. Tal teoria apoia-se na suposição de que a estabilidade observada nos fenômenos sociais é da mesma ordem daquela verificada nos fenômenos celestes e físicos, o que vai levar o teórico a aplicar aos primeiros o modelo de distribuição de regularidades que era utilizado no cálculo astronômico conhecido como "curva de erros" ou lei de variação. 
Esse recurso matemático foi utilizado pela primeira vez para calcular com precisão o valor verdadeiro de uma certa grandeza $\mathrm{X}^{12}$. Notava-se então, como Laplace explicitou, que, por mais variações que existam entre as médias de uma certa grandeza calculadas em experimentos independentes, elas tendem a se anular, aproximando-se mais e mais da média verdadeira, após a realização de um número infinito de experimentos.

É importante frisar que, para esses astrônomos, a curva de erros constituía a representação gráfica não das anomalias presentes nas coisas, mas, sublinha Porter, "da imperfeição das mensurações técnicas ou da imprecisão da inferência dos fenômenos que ocorrem em número finito para as suas causas subjacentes" (1985, p. 66). Porém, com Quêtelet, pela primeira vez se concebe que as variações apresentadas entre as médias resultantes de experimentos independentes são causadas por erros da própria natureza, de modo que a curva de erros representaria de alguma maneira uma variação natural.

Essa articulação entre erro e variação natural é fundamental para Quêtelet chegar ao que ele considerava a sua descoberta mais importante para a ciência social: a diferença entre média verdadeira e média estatística. Essa última corresponderia ao valor médio obtido pela mensuração de grandezas distintas. Neste caso, observa Poter, "como as várias estruturas são designadas diferentemente, a média teria apenas um reduzido valor na sustentação da ideia do seu caráter coletivo" (1985, p. 67). A média verdadeira, por sua vez, resultaria das medições realizadas numa única grandeza, de modo que gradualmente as variações convergiriam para um valor determinado de acordo com a lei de erros. Quêtelet se refere à ideia de média verdadeira quando, em sua Letters, apresenta a teoria do homem médio com um argumento analógico - recurso estilístico comum nos textos do estatístico. Ele se indaga sobre o que aconteceria caso cem escultores fossem convidados para copiar a estátua do "Gladiador", cujas dimensões foram anteriormente medidas quinhentas vezes. Segundo o teórico, provavelmente o número de erros de medida aumentariam, mas

\footnotetext{
12 Essa lei foi extensamente incorporada pela astronomia. Como observa Porter: "the same function was incorporated by Gauss and Laplace into the method of least squares, a technique for reducing a great number of independent stellar observations to the value that minimizes the expected errors. It was later applied to individual errors of observation in astronomy and surveying, in which context the model of small errors summing to a regular distribution was brought out with clarity by G. H. L. Hagen just a few years before Quêtelet developed his constitutive application of it" (1985, p. 66). Conhecida também como "curva de Gauss" - é assim que Canguilhem se refere a ela (2007, p. 100), essa função ainda é largamente utilizada pela estatística.
} 
se os copistas não trabalhassem com ideias pré-concebidas, exagerando ou diminuindo algumas proporções, de acordo com pré-juízos de suas escolas particulares, e se suas incorreções fossem apenas acidentais, as cem mensurações agrupadas em ordem de magnitude ainda apresentariam uma notável regularidade, e sucederiam uma à outra segundo a ordem assinalada pela lei de possibilidade (apud Turner, 1986, p. 70).

Não é à toa, portanto, que Quêtelet realiza incansáveis coletas de dados empíricos: a taxa de casamentos numa certa cidade, a altura de 100.000 franceses alistados no exército, a largura do peito de 5.738 soldados escoceses etc. Como observa Canguilhem, "quanto maior o número de medições operadas, mais as causas perturbadores acidentais se compensarão e se anularão, e mais claramente aparecerá o tipo geral” (2007, p. 100) A esse tipo geral, Quêtelet chama de homem médio, que, como bem observou Beirne, “ocupa, entre todos os homens, um lugar que o estatístico concebe como análogo ao centro de gravidade para a matéria” (1987, p. 1151).

A analogia é precisa: da mesma maneira como o centro de gravidade é o ponto em que se equilibram todas as forças de atração que atuam sobre um corpo, o homem médio constitui o valor em que se compensam as influências que fazem variar todas as características sociais. A importância epistêmica do homem médio para a física social deriva justamente da sua estabilidade e da sua imunidade às causas particulares. Como explica Porter,

\footnotetext{
Assim como o astrônomo pode, ao menos como uma primeira aproximação, negligenciar a infinitude de partículas que compõem qualquer corpo celeste, e, ao contrário, realizar cálculos como se toda sua matéria estivesse localizada no centro, então o físico social pode resolver a trajetória do "corpo social" simplesmente traçando o progresso do homem médio (1985, p. 60).
}

Se o progresso do corpo social é o progresso do homem médio, então apenas causas gerais são capazes de produzir fatos sociais, enquanto que causas particulares, arbitrárias, atribuídas à espontaneidade da ação humana, não acarretam verdadeiros efeitos sociais. Canguilhem nota muito claramente de que maneira a teoria das médias de Quêtelet acaba por anular o efeito normativo de variações individuais pela sua subsunção a uma norma mais geral, de forma que

Quêtelet expressamente afirmava que ele não reconhecia à variação individual concernente a um caractere dado (flutuação) nenhum outro sentido que aquele de um acidente verificando as leis do acaso, isto é, leis que exprimem a influência de uma 
quantidade não assinalável de causas não sistematicamente orientadas, e cujos efeitos, por conseguinte, tendem a sua anular por compensação progressiva (2007, p. 100).

Em suma, o estatístico é capaz de mostrar que os erros e desvios individuais não passam de epifenômenos, na medida em que eles próprios estão sujeitos a uma lei invariável: a lei de erros. Conforme vimos anteriormente, a curva de erros revela que todas as causas contingentes, produtoras de anomalias, tendem a se mostrar ineficientes na produção de verdadeiras transformações, já que, no curso de infinitas medições, elas se anulam em torno de uma média verdadeira. Com isso, Quêtelet, assim como Durkheim, recusam às variações qualquer capacidade normativa em nome de uma concepção invariável de normal identificado à média verdadeira.

Até aqui, acompanhamos o esforço de Durkheim no sentido de reduzir o conceito de normal ao conceito de média, isto a fim de poder estabelecer um critério objetivo para a distinção entre fenômenos normais e fenômenos patológicos. Essa redução, ensina Canguilhem em 1947, "responde à preocupação de exorcizar todo julgamento de valor na medida em que ele implica uma referência à livre decisão subjetiva. Trata-se de saber se esta eliminação é tão definitiva quanto se acredita" (1947, p. 20). De fato, para o filósofo francês, a redução do normal a uma questão de medida não é capaz de esvaziar o conceito de norma do seu conteúdo axiológico, pois Canguilhem nunca deixou de insistir na ideia que qualquer concepção de norma comporta a referência a algum valor positivo ou ideal (2007, p. 76). O problema torna-se, então, saber o que significa esse valor, qual a sua proveniência, no quadro de uma concepção objetiva de normalidade. Na resposta a essa questão, descobre-se um movimento reflexivo maior do pensamento de Canguilhem que consiste em revelar os pressupostos filosóficos encobertos sob a aparente objetividade da visão científica do normal quantitativo. Que pressupostos seriam esses? No Essai, Canguilhem mostra que eles são derivados de uma “(...) tradição filosófica realista, segundo a qual toda generalidade sendo o sinal de uma perfeição e toda perfeição sendo a realização de uma essência, uma generalidade de fato observável toma o valor de perfeição realizada, um caráter comum assume o valor de tipo ideal" (CANGUILHEM, 2007, p. 76). Assim, para essa filosofia realista, o tipo médio é normal porque ele exprime a perfeição de uma essência, seu valor derivando não da capacidade produtora de uma subjetividade normativa, mas da realidade substancial de um ser que o fundamenta. Esse tipo de raciocínio, Canguilhem o revela em Quêtelet, mostrando que era recorrendo a uma ontologia de cunho marcadamente teológico que o estatístico podia 
explicar a regularidade dos fenômenos normais expressa pela média verdadeira:

Em suma, segundo Quêtelet, a existência de uma média é o sinal incontestável da existência de uma regularidade, interpretada num sentido expressamente ontológico: "a principal ideia para mim é de fazer prevalecer a verdade e de mostrar o quanto o homem está submetido às leis divinas e com qual regularidade ele as realiza. Essa regularidade, de resto, não é particular ao homem: é uma das leis da natureza que pertencem aos animais e as plantas, e talvez não a espantará não a ter reconhecido antes" (CANGUILHEM, ibidem, p. 101).

Tudo se passa, então, como se o limite encontrado pela explicação da normalidade pela sua identificação à quantidade fosse ultrapassado por uma ontologia para a qual certos fenômenos são mais gerais porque eles exprimem uma perfeição essencial já existente. Não é por acaso que o projeto filosófico canguilhemeano envolverá também uma crítica a uma teoria realista do valor, crítica que se fará, como veremos adiante, a partir de uma filosofia da vida. Cabe-nos agora, porém, seguir a investigação canguilhemeana sobre a forma específica que assume essa filosofia realista no caso da sociologia de Durkheim, já que não se tratará mais, para o sociólogo francês, de fazer apelo a um ser divino ou a leis divinas para justificar a regularidade dos fenômenos sociais.

\section{Uma ontologia biológica do social}

De início, Canguilhem faz ver que o próprio Durkheim reconhece as dificuldades de sustentar uma concepção puramente objetiva do normal. Junto com a constatação de que "a generalidade constitui também um fato que necessita ser explicado e que, por isso mesmo, reclama uma causa" (DURKHEIM, 1987, p. 58), retorna, pelas portas do fundo, a teleologia que o teórico se esforçara por exorcizar do seu campo de análise ao buscar um fundamento objetivo para a distinção entre normal e patológico:

Após ter decidido encontrar um critério empírico de distinção entre o normal e o patológico, ele [Durkheim] não pode deixar de transformar o fato em direito e de fazer o que ele recomenda expressamente não fazer: colocar em relação o normal e o patológico com as forças vitais. Essa relação é a relação de utilidade. E assim reaparece toda a teleologia que se tinha desviado da definição do conceito de normal 
Com efeito, após reconhecer por meio de critérios objetivos e facilmente perceptíveis os sinais da normalidade, é preciso explicá-los por uma causa. É a determinação dessa causa que vai fundar de maneira sólida aquilo que, pela observação, tinha-se revelado como um fato: a existência de certos traços frequentes, sob formas igualmente frequentes, num dado momento do desenvolvimento da espécie:

\footnotetext{
O caráter normal do fenômeno será, com efeito, incontestável, se demonstrarmos que o sinal exterior que de primeiro o tinha revelado não era puramente aparente, mas fundado na natureza das coisas; se, numa palavra, se puder erigir esta normalidade de fato em normalidade de direito (1987, p. 59).
}

A procura durkheimeana pelo fundamento de direito da normalidade empiricamente identificável se inicia com o conceito de utilidade. Com efeito, segundo observou Canguilhem na citação precedente, o conceito de utilidade fornece a Durkheim uma primeira explicação para a normalidade de certos fenômenos sociais, na medida em que se poderia afirmar que esses são gerais porque são úteis (DURKHEIM, ibidem, p. 63), isto é, vantajosos para a adaptação de uma determina espécie social.

Contudo, o recurso à noção de utilidade se revela insuficiente para Durkheim determinar as condições de possibilidade da normalidade de fato. Essa insuficiência decorre, sobretudo, da maneira como aquela noção é compreendida no quadro de uma interpretação psicológica, segundo a qual a utilidade é o valor que se dá à relação entre uma finalidade particular e os meios de que se dispõe para alcançá-la. Tomada nessa acepção, o conceito de utilidade parece não dar conta de explicar a "espantosa regularidade com que esses [os fenômenos sociais normais] se reproduzem nas mesmas circunstâncias" (Ibidem, p. 94), já que, no interior de uma dada sociedade, não apenas os fins variam segundo os indivíduos, como também a maneira de realizar fins semelhantes muda de homem para homem. Em suma, para Durkheim, “mostrar a utilidade de um fato não é explicar como se originou nem porque ele é tal qual se apresenta" (Ibidem, p. 90).

Impõe-se, então, ao sociólogo francês a tarefa de encontrar para a noção de utilidade 
uma explicação que não seja dependente de uma concepção psicológica de finalidade. Quanto a essa recusa da psicologia, vale sublinhar que, em Les règles, Durkheim se esforça justamente para assegurar a autonomia epistemológica da sociologia em relação àquilo que se chamava então de método psicológico ${ }^{13}$. Para tanto, o sociólogo francês insiste na irredutibilidade do social em relação ao orgânico e ao psíquico, definindo-o por suas características especiais: “(...) eles [os fatos sociais] consistem em maneiras de agir, de pensar e de sentir exteriores ao indivíduo e que são dotadas de um poder de coerção em virtude do qual eles se impõem a ele ${ }^{14, ”}$ (Ibidem, p. 5). Na crítica à explicação finalista, é o próprio lugar soberano da consciência individual como criadora da ordem social que se vê ameaçado pela natureza coercitiva e exterior da sociedade:

Como não se vê neles [nos fatos sociais] senão combinações puramente mentais, parece que se devem produzir por si mesmos desde que a ideia deles surja, uma vez, porém, que sejam dados como úteis. Mas, como cada um deles é uma força que domina a nossa, possuindo uma natureza que lhe é própria, não seria suficiente ter apenas o desejo ou a vontade de produzi-lo para suscitá-lo. Para isto, é preciso que forças capazes de criar esta força determinada, que naturezas capazes de produzir esta natureza especial sejam dadas (Ibidem, p. 90)

A utilidade dos fenômenos sociais, em que se fundamenta a sua normalidade objetiva, deve ser procurada não do lado de uma suposta consciência individual autônoma no estabelecimento dos seus próprios fins, mas num psiquismo de outra natureza, no qual consiste a sociedade:

\footnotetext{
${ }^{13}$ No capítulo V de Les règles, Durkheim atribui este método à sociologia de Comte e de Spencer, fornecendo para ele a seguinte definição: "En même temps qu'elle est finaliste, la méthode d'explication généralement suivie par les sociologues est essentialement psychologique. Ces deux tendances sont solidaires l'une de l'autre. Em effet, si la société n'est qu'un système de moyens institués par les hommes em vue de certaines fins, ces fins ne peuvent être qu'individuelles; car, avant la société, il ne pouvait exister que des individus. C'est donc de l'individu qu'émanent les idées et les besoins qui ont déterminé la formation des sociétés, et, si c'est de lui que tout vient, c'est nécessairement par lui que tout dois s'expliquer. D'ailleurs, il n'y a rien dans la société que des consciences particulières; c'est donc dans ces dernières que se trouve la source de toute l'évolution sociale. Par suite, les lois sociologiques ne pourront être qu'un corollaire des lois plus générales de la psychologie (...)" (1987, p. 97).

${ }^{14} \mathrm{Na}$ continuação dessa afirmação, Durkheim insiste mais uma vez na distinção entre o social, o orgânico e o psíquico: "Por conseguinte, eles não poderiam se confundir com os fenômenos orgânicos, já que eles consistem em representações e em ações; nem com os fenômenos psíquicos, os quais somente tem existência na consciência individual e por ela. Eles constituem então uma espécie nova, sendo a eles que deve ser dada e reservada a qualificação de sociais" $(1987$, p. 5).
} 
Agregando-se, penetrando-se, fundindo-se, as almas individuais dão nascimento a um ser psíquico, se quisermos, mas que constitui individualidade psíquica de novo gênero. É, pois, na natureza desta individualidade, e não na das unidades componentes, que é preciso ir buscar as causas próximas e determinantes dos fatos que nela se produzem (Ibidem, p. 103).

A normalidade de direito pela qual buscava Durkheim não é outra coisa que a própria natureza social. Até aqui, parece que nos encontramos diante de um projeto inovador de crítica da sociedade que não faz distinção entre psicologia individual e psicologia social, como se o sociólogo francês reconhecesse a gênese social do que sempre contamos como dizendo respeito a uma interioridade psíquica inalienável. Contudo, é numa outra direção que caminha a interpretação canguilhemeana. Para o autor do Essai, é precisamente a tentativa durkheimeana de estabelecer a normalidade social sobre a natureza social que revela o compromisso dessa teoria com uma ontologia para a qual "sociedade é um ser (Durkheim fala de alma coletiva) cujas propriedades não se encontram na escala dos seus pseudocomponentes. É então com uma ontologia social que nós estamos lidando" (CANGUILHEM, 1947, p. 4). Em outra passagem, o filósofo francês sublinha que:

\footnotetext{
Durkheim apenas conhece a sociedade sob o aspecto da unidade. No fundo, nenhuma diferença com A Comte. Comte opõe o indivíduo e a humanidade; Durkheim opõe o indivíduo e a sociedade. Mas se a diferença existe nos termos, ela não existe na noção. A noção é aquela de um ser transcendente ao indivíduo cuja realidade seja capaz de portar o valor supremo, aquela que serve para regular e reger definitivamente toda a atividade do indivíduo. Retenhamos desde já dois traços: ontologismo sociológico e monismo sociológico (1947, p. 1).
}

Ontologia social: tal é o nome que podemos atribuir à filosofia realista que a sociologia de Durkheim assume sem dizer seu nome. Nessa ontologia se ancora a explicação última da normalidade social, na medida em que o valor normal atribuído àqueles fenômenos sociais que são mais gerais decorre do fato deles serem os únicos a expressarem o ser social que os transcende. A ideia de normalidade se acha atrelada assim a mera realização de disposições essenciais existentes a priori, como se o normal não fosse ele mesmo normativo, ou seja, criador de novas formas de vida.

Portanto, se há algum conteúdo axiológico na concepção durkheimeana de normal, então ele só pode derivar de uma essência social objetiva, e não dos sujeitos implicados nos 
processos sociais. A experiência subjetiva de insatisfação diante dos valores realizados pelas normas sociais não é capaz, para Durkheim, de contestar a normalidade social pela afirmação de outras normas. Por isso que os conflitos vivenciados pelos indivíduos em relação às normas sociais que os constrangem não chegam a ameaçar a unidade do ser social, cuja essência aquelas normas realizam.

Não é de se estranhar, então, que Canguilhem diagnostique na sociologia durkheimeana a ausência de uma teoria do conflito. Por mais que seja possível indicar neste terceiro capítulo de Les règles uma oscilação na direção de uma concepção valorativa do normal, ela nunca se realiza. A redução da normalidade à generalidade, à frequência estatística, como primeira parte do método, é suficiente para neutralizar o sentido axiológico de noções que, para Canguilhem, comportam um sentido normativo: tal é o caso da noção de adaptação. Não é por outra razão que, no texto durkheimeano, ela aparece como um pacto consumado de estabilidade definitiva entre o organismo e o meio (CANGUILHEM, 1947, p. 16). Como observa Canguilhem no curso de 1947, "Durkheim raciocina sobre a adaptação como sobre um resultado obtido, enquanto que é necessário raciocinar sobre ele como sobre um efeito à obter. Falta a Durkheim tanto no exame dos fatos biológicos quanto no exame dos fatos sociológicos, o sentido do caráter conflitual e crítico da vida" (Ibidem, p. 17). A crítica à maneira como Durkheim entende a adaptação em termos de adequação do humano às normas do meio social torna-se mais compreensível quando compreendida à luz da concepção canguilhemeana de adaptação. Essa será uma questão sobre a qual o filósofo francês voltará muitas vezes ao longo do seu trabalho, insistindo, sempre, na existência de um tipo de adaptação que é capaz de ultrapassar as exigências imediatas do meio, forçando a sua transformação (CANGUILHEM, 2007, p. 197). Ora, tal concepção não pode encontrar lugar na teoria durkheimeana, posto que reconhecer a existência de uma adaptação não subordinada às normas do meio social seria o mesmo que afirmar a existência de um normal para além do ser social, um normal que resultaria da experiência de profunda indeterminação do indivíduo frente à sociedade, mas que, por isso, seria também capaz de colocar em questão a ideia durkheimeana de que a sociedade porta os valores supremos reguladores da atividade individual.

Devemos insistir nessa interpretação de Canguilhem segundo a qual a sociedade, na teoria social durkheimeana, fornece as normas ou princípios de regulação dos indivíduos. Será na forma do problema em torno da regulação social que Durkheim, tão insistentemente 
evocado nos primeiros escritos de Canguilhem, retornará posteriormente à reflexão canguilhemeana, sobretudo no final dos anos 50 e na década de 60, quando o filósofo criticará a identificação entre o organismo e a sociedade. Como veremos no último capítulo desta dissertação, tal identificação está suposta na afirmação de que a sociedade possui uma finalidade interna ou um princípio imanente de regulação semelhante àquele que existe nos organismos.

Antes, porém, dos anos 50, Canguilhem denunciava sob a ontologia social durkheimeana uma filosofia biológica que parece não ter sido eliminada pelos esforços epistemológicos de Durkheim ao distinguir, em Les règles, o objeto da biologia do objeto da sociologia: "é então importante destacar que defendendo a originalidade do objeto social sobre o objeto biológico, Durkheim cedeu à ascendência da filosofia biológica da época" (CANGUILHEM, 1947, p. 24). Filosofia biológica essa que se caracterizava pela forte ascendência da biologia positiva de Comte e da fisiologia de Claude Bernard, de modo a conceber que, para se determinar a norma de regulação do organismo social, a sociologia poderia se valer dos métodos utilizados pelas ciências da vida para o estabelecimento do normal fisiológico. Não é por acaso, então, que Durkheim importe dessas ciências não apenas as categorias de saúde e doença, mas a forma métrica que torna possível distingui-las objetivamente. Daí porque, para Canguilhem:

No fundo, o que se deve reprovar a Durkheim é de ter adotado, sem crítica, os conceitos fisiológicos clássicos, do fim do século XIX e desde Comte e Claude Bernard, conservando o problema do normal e do patológico, é de ter admitido como um dogma que 'fisiológico' equivale ao mesmo tempo a 'são' e a 'média'. Ora, é precisamente este dogma que deve ser colocado em questão (1942-1943, p. 50).

O questionamento desse dogma será o objeto de toda a primeira parte do Essai, que o nosso próximo capítulo tratará de analisar retirando dela as questões fundamentais que levarão Canguilhem a formular sua concepção de vida em termos de normatividade vital. 


\title{
A gênese biológica da normalidade social
}

A análise canguilhemeana de Les règles de la méthode sociologique concluía afirmando que a sociologia de Durkheim buscou se consolidar como ciência a partir da extensão hiperbólica de conclusões teóricas regionais, oriundas da fisiologia, referentes ao modo de relação entre os fenômenos vitais normais e patológicos ${ }^{15}$. O que Durkheim então pretendia era "fundar a validade contestada dos conceitos sociológicos sobre a validade provada, segundo ele, dos conceitos fisiológicos correspondentes" (CANGUILHEM, 19421943, p. 48). Tal diagnóstico histórico ressoa explicitamente nas análises arqueológicas de Foucault:

\begin{abstract}
Se as ciências do homem apareceram no prolongamento das ciências da vida, é talvez porque estavam biologicamente fundadas, mas é também porque o estavam medicamente: sem dúvida por transferência, importação e, muitas vezes, metáfora, as ciências do homem utilizaram conceitos formados pelos biólogos; mas o objeto que eles se davam (o homem, suas condutas, suas realizações individuais e sociais) constituía, portanto, um campo dividido segundo o princípio do normal e do patológico. Daí o caráter singular das ciências do homem, impossíveis de separar da negatividade em que apareceram, mas também ligadas à positividade que situam, implicitamente, como norma (2004, p. 39).
\end{abstract}

O principal legado da fisiologia às ciências humanas não foi tanto dos conceitos biológicos de saúde e patologia, mas, mais precisamente, o de certo princípio de relação entre eles, princípio que procurava reduzir sua radical diferença qualitativa à forma da quantidade. Essa redução, como vimos anteriormente, era o que permitia a Durkheim defender o caráter normativo da sociologia, na medida em que, uma vez determinado o estado de saúde social, poder-se-ia intervir nos casos desviantes, reconduzindo-os à normalidade. A questão metodológica consistia, então, em procurar "um critério objetivo, inerente aos próprios fatos, que nos permita, nas diversas ordens de fenômenos sociais, distinguir cientificamente a saúde da doença (...)" (DURKHEIM, 1987, p. 49).

Esse critério é, para Durkheim, a frequência com que um determinado fenômeno pode ser encontrado na extensão de uma espécie. Ele será um fenômeno normal se ocorrer, senão em todos os indivíduos, ao menos na maior parte deles, com variações mínimas e

\footnotetext{
${ }^{15}$ Algumas décadas depois dessas análises sobre Durkheim, Canguilhem chamará de ideologia científica todo sistema explicativo, com pretensões científicas, constituído a partir da importação de conceitos de uma ciência já estabelecida. Acerca disso, conferir o célebre artigo Qu'est-ce qu'une idéologie scientifique?, In: CANGUILHEM, Georges, 1977, p. 33-45.
} 
circunscritas a limites bem definidos. A reunião desses caracteres normais resulta no que Les règles designava como "tipo médio" ou "tipo geral”, em relação ao qual qualquer desvio será avaliado como patológico. Assim, afirma o sociólogo, “(...) poder-se-á dizer que o tipo normal se confunde com o tipo médio, e que todo desvio em relação a esse patamar de saúde é um fenômeno mórbido" (Ibidem, p. 56, grifos nossos).

A partir dessa citação é possível extrair algumas das características definidoras do conceito durkheimeano de normal. Em primeiro lugar, Durkheim concebe o normal como um fato social, cuja exata apreensão por parte do cientista exige que ele seja considerado isolado das suas manifestações individuais. Em outras palavras, a maneira como certos fenômenos sociais são experenciados e avaliados pelos indivíduos não conta na determinação da sua normalidade ou anormalidade, para a qual o único critério admitido pelo método sociológico é a frequência com que eles ocorrem numa espécie determinada, num momento determinado: "um fato social é normal para um tipo social determinado considerado numa fase determinada de seu desenvolvimento, quando se produz na média das sociedades desta espécie, consideradas na fase correspondente da sua evolução" (Ibidem, p. 64). Assim, e em segundo lugar, excluída toda referência ao seu valor individual, o normal é identificado com o mais frequente ou com a média. Em terceiro lugar, esse traço normal ou médio é também considerado saudável, a determinação do valor sendo posterior e dependente do estabelecimento da frequência: "cada espécie tem a sua saúde porque tem o tipo médio que lhe é próprio (...)" (Ibidem, p. 56). Em quarto lugar, é somente após a identificação do tipo normal que se pode estabelecer os fenômenos desviantes, que são da mesma natureza dos primeiros (Ibidem, p. 47). Finalmente, o sociólogo identifica os fenômenos desviantes ou anômalos à patologia, como se todo anômalo necessariamente portasse um valor negativo.

Saúde, patologia e normalidade são conceitos manifestamente clínicos que Durkheim traz para o campo da sociologia a fim de conferir a essa a cientificidade atribuída àquela. Porém, cabe-nos perguntar, o que autorizava Durkheim a considerar como válidos cientificamente conceitos oriundos de um domínio que parece profundamente dependente da experiência do paciente, da relação que este estabelece com o seu médico, enfim, de um solo subjetivo oposto às expectativas de objetividade das ciências?

É que entre essa clínica da subjetividade e aquela a que recorre Durkheim há um breve intervalo em que a fisiologia se autonomiza da escuta médica no leito do enfermo, 
transformando-se na ciência médica por excelência. Leriche ${ }^{16}$ sintetizou esse processo em duas frases que Canguilhem tornou célebres: "se se quer definir a doença, então é preciso desumanizá-la", e, mais enfaticamente, "na doença, o que há de menos importante é, no fundo, o homem" (apud CANGUILHEM, 2007, p. 53). Desumanização da doença decorrente da substituição do fundamento da clínica: a subjetividade vivente cede lugar à objetividade das constantes e dos cálculos fisiológicos.

Ao adotar como critério fundamental de partilha dos fenômenos sociais a distinção entre o normal e o patológico, Durkheim pretendia assegurar à investigação sociológica o mesmo estatuto de objetividade que a fisiologia supostamente conquistara pela redução das diferenças qualitativas entre os estados vitais a uma variação apenas de grau. Ora, vimos inicialmente que a imposição da forma quantidade aos fenômenos sociais era condição necessária, segundo Canguilhem, para que Durkheim eleva-se a sociologia à dignidade de ciência da sociedade num contexto teórico em que a inteligibilidade dos objetos dependia da sua submissão a uma medida tomada como norma. No âmbito das ciências da vida, é o normal fisiológico que fornece essa medida, possibilitando, a partir dele, a determinação, em termos de variação quantitativa, dos fenômenos vitais patológicos.

Tal tese de que o patológico não é outra coisa que uma variação, para mais ou para menos, de uma medida fisiológica definida como normal se tornou “(...) no curso do século XIX, uma espécie de dogma cientificamente garantido, cuja extensão no domínio da filosofia e da psicologia pareciam comandadas pela autoridade que os biólogos e os médicos lhe reconheciam” (CANGUILHEM, 2007, p. 14). Na França, observa Canguilhem, essa autoridade lhe foi garantida, sobretudo, pelos trabalhos de Comte e de Claude Bernard, donde a tese da identidade real entre saúde e doença se disseminou para outros domínios de conhecimento, dentre eles a sociologia.

\section{Uma estática biológica: a fisiologia de Comte}

Antes mesmo que Claude Bernard, Leriche e Bachelard, Comte é o filósofo a quem Canguilhem consagra o maior número de estudos ${ }^{17}$. Não obstante as profundas diferenças

\footnotetext{
${ }^{16}$ Não dedicaremos a Leriche um estudo mais minucioso pois entendemos que suas teses sobre a relação entre o normal e o patológico estão extremamente próximas as de Claude Bernard. Detalharemos, no entanto, os possíveis pontos em que os dois médicos divergem.

${ }^{17}$ Segundo a listagem dos estudos canguilhemeanos sobre Comte, elaborada por Braunstein (1998, p. 96, n3-4), além do estudo La théorie de l'ordre et du progrès chez Auguste Comte, realizada em 1926, sob a direção de C. Bouglé para a obtenção do Diploma de estudos superiores, na Sorbonne, e do capítulo dedicado à Comte no
} 
entre os dois pensadores, Comte ocupa um lugar central no projeto filosófico canguilhemeano por partilhar com esse de objetos comuns de reflexão, tais como a história das ciências, a biologia, a organização social e o problema da normalidade. Porém, como nota Braunstein, "se ele [o pensamento de Comte] considera os mesmos objetos que Canguilhem, não chega, porém, a tirar daí uma teoria da novidade e da emergência dos valores" (1998, p. 110). Na interpretação canguilhemeana, tudo se passa como se Comte permanecesse prisioneiro do fato seja ao pensar a história como o progressivo desenvolvimento de uma verdade desde sempre existente seja ao afirmar que a relação entre o organismo e o meio obedece a forma de um consenso ou harmonia da qual toda ideia de conflito, debate, transformação está ausente.

O diagnóstico e a crítica dessa redução comteana dos valores aos fatos, Canguilhem faz de maneira explícita e radical no Essai. Em linhas gerais, na perspectiva da crítica canguilhemeana, "o erro de Comte é de confundir o direito com o fato, rebater a norma sobre a média, a qualidade sobre a quantidade" (BRAUNSTEIN, ibidem, p. 110). No âmbito da biologia positiva, esse erro se revela no papel de "axioma geral" (CANGUILHEM, 2007, p. 19) atribuído por Comte ao que ele designa como "princípio de Broussais", para o qual "os fenômenos patológicos são, nos organismos vivos, somente variações quantitativas, para mais ou para menos, dos fenômenos vitais correspondentes" (Ibidem, p. 14). É sobre esse princípio que o pensamento comteano pretende fundar, em primeiro lugar, a objetividade da biologia positiva, dissipando os impasses que os fenômenos vitais parecem colocar para o seu estudo científico, e, em segundo lugar, a própria ciência do organismo social. Nesse sentido, sublinha Canguilhem: "eis um princípio de nosologia investido de uma autoridade universal, aí compreendida na ordem política. Está assegurado, afinal, que é essa última utilização projetada que lhe confere retroativamente todo valor do qual ele já é portador, segundo Comte, na ordem biológica" (Ibidem, p. 20). Mas, como foi o caso de mostrar no capítulo anterior, também Durkheim, na esteira de Comte, conferiu a esse princípio biológico de compreensão dos fenômenos vitais um papel arquitetônico para a constituição da sociologia. Vejamos, então, como a biologia comteana elabora a partir de Broussais a tese da identidade essencial entre o normal e o patológico.

Essai, Canguilhem publicou também La philosophie biologique d'Auguste Comte et son influence en France au XIXe. Siècle, L'école de Montpellier jugée par Auguste Comte, Histoire des religions et histoire des sciences dans la théorie du fetichisme chez A. Comte, esses três artigos reunidos nos Études d'histoire et de philosophie des sciences, Histoire de l'homme et nature des choses selon Auguste Comte dans le Plan des travaux scientifiques nécessaires pour réorganiser la société, 1822 (Études philosophique, juil. -sept. 1974), Auguste Comte (enciclopédia italiana Scienziati e tecnologi dalle origini al 1875, Milão, 1975), L'histoire des sciences de l'organisation de l'abbé Maupied (Revue d'histoire des sciences, 32, 1979), e Émille Littré, philosophe de la biologie et de la médecine (Actes du colloque Émile Littré, 1801-1881, Paris, 1982). 
$\mathrm{Na}$ quadragésima lição do Cours de Philosophie Positive, Considérations philosophiques sur l'ensemble de la science biologique, após analisar o objeto e o campo geral das pesquisas biológicas, Comte dedica-se ao exame dos métodos pelos quais os fenômenos vitais podem ser apreendidos pelo cientista.

O primeiro desses métodos consiste no uso direto dos sentidos, particularmente da visão, que, na biologia, conheceu um significativo incremento graças à invenção de aparelhos artificiais encarregados de aperfeiçoar as sensações naturais.

Contudo, o meio de investigação mais adequado ao estudo dos corpos vivos é, segundo Comte, o método comparativo. O homem adulto e normal é a unidade essencial a partir do qual "se ordenam os termos sucessivos da imensa série biológica, à medida que eles se distanciam mais deste tipo fundamental, descendo até às organizações mais simples e aos modos de existência mais imperfeitos" (ibidem, p. 183).

Entre o uso dos sentidos e o método comparativo, Comte insere a experimentação. De início, o filósofo reconhece que a natureza dos fenômenos vitais parece colocar obstáculos intransponíveis à aplicação racional de um tal procedimento de pesquisa. Com efeito, na medida em que a experimentação consiste geralmente em introduzir uma modificação bem determinada no fenômeno, a fim de avaliar as variações dela decorrentes, o uso eficaz desse procedimento precisa obedecer a duas condições fundamentais: 1-) a mudança introduzida tem que ser totalmente compatível com a existência do fenômeno; 2-) os dois casos comparados, ou seja, aquele que foi alterado e o que não foi, devem se distinguir apenas no que diz respeito à modificação introduzida (cf. Ibidem, p. 169).

Todavia, afirma Comte, "a natureza dos fenômenos biológicos deve tornar quase impossível uma suficiente realização dessas duas condições preliminares, sobretudo da segunda" (ibidem, p. 169). De fato, a complexidade observada nesta categoria de fenômenos, cuja existência é garantida por uma grande quantidade de influências, externas e internas, harmonizadas segundo limites estritos de variação, acarreta gigantescas dificuldades: primeiramente, porque praticamente impede que se determine o grau ou a extensão de uma modificação; em segundo lugar, porque um fenômeno modificado não é o mesmo fenômeno anterior acrescido ou subtraído de algo, mas é outro fenômeno: "ainda que ela [a perturbação] possa ser primitivamente restrita à modificação direta de apenas uma das condições do 
fenômeno, ela afeta quase imediatamente a maior parte das outras em virtude do seu consensus universal" (ibidem, p. 169) ${ }^{18}$.

A minuciosa apreciação filosófica que Comte realiza do método experimental não pretende condenar a sua aplicação em biologia (ibidem, p. 173). Trata-se, antes, de apontar para as dificuldades que ele impõe à investigação dos fenômenos vitais, a fim de reconhecer, em detrimento do modelo experimental oriundo das ciências físicas e químicas, a "alta superioridade necessária da análise patológica" (ibidem, p. 176 - grifos nossos), "considerada como oferecendo, para a biologia, de uma maneira bem mais satisfatória, o verdadeiro equivalente geral da experimentação propriamente dita" (ibidem, p. 174).

O privilégio concedido por Comte ao método patológico se deve ao fato de que, para ele, a doença é "uma espécie de experimentação espontânea" (ibidem, p. 175), permitindo, como nota Canguilhem, "uma comparação entre os diversos estados anormais do organismo e o seu estado normal" (2007, p. 21). Com efeito, a patologia, assim como a experimentação artificial direta, mas sem incorrer nos problemas indicados acima, é capaz de "alterar o estado natural do organismo, de forma a apresentar sob um aspecto mais evidente a influência própria em cada um dos seus diferentes fenômenos" (ibidem, p. 175).

Todavia, se a patologia altera "o estado natural do organismo", de que forma Comte ainda pode justificar o valor heurístico deste "método espontâneo" na comparação, pela via da observação, do vivente doente com o normal?

Para responder a essa questão é preciso levar em conta a filiação intelectual da patologia positiva para com o princípio de Broussais, como transparece neste longo trecho:

\begin{abstract}
Segundo o princípio eminentemente filosófico que serve desde então de base geral e direta à patologia positiva, e do qual nós devemos o estabelecimento definitivo ao gênio de M. Broussais, o estado patológico não difere radicalmente do estado fisiológico, a respeito do qual ele apenas poderia constituir, sob um aspecto qualquer, um simples prolongamento, mais ou menos extenso, dos limites de variação, seja superiores, seja inferiores, próprios a cada fenômeno do organismo normal, sem nunca poder produzir fenômenos verdadeiramente novos, que não teriam, a um certo grau, seus análogos puramente fisiológicos (ibidem, p. 175-176).
\end{abstract}

Além de uma teoria atomista das doenças segundo a qual essas não seriam outra coisa que os sintomas decorrentes de lesões tissulares localizáveis (CANGUILHEM, 2007, p. 18), a

\footnotetext{
${ }^{18}$ Devido às dificuldades impostas à experimentação pelo consensus biológico, o método comparativo se torna, para Comte, "o mais adequado para o estudo de um objeto - a vida- que não pode ser apreendido exclusivamente através de processos de experimentação ou da pura observação. Somente a comparação pode, enquanto meio de investigação, fazer com que se torne o 'obstáculo da totalidade orgânica' ou do seu consensus" (BENOIT, 1999, p. 299).
} 
contribuição de Broussais para a filosofia positiva de Comte está, sobretudo, na formulação de uma concepção quantitativa das relações entre o normal e o patológico, de acordo com a qual a diferença entre esses estados não se encontra nas essências mas nas intensidades.

A explicação em termos quantitativos das relações entre a saúde e a doença se tornou possível porque Broussais “(...) reconhecia na excitação o fato vital primordial” (CANGUILHEM, ibidem, p. 23). Isso quer dizer que, para o médico francês, todos os fenômenos vitais podem ser reduzidos a uma grandeza mensurável, cujo valor médio determina a quantidade normal de excitação necessária para a manutenção da vida. Nesse contexto, a patologia passa a ser explicada pela diminuição e, principalmente, pelo aumento da excitação num certo tecido, levando assim a um estado anormal ou à inflamação ${ }^{19}$.

Ao definir a doença como um aumento da intensidade normal de excitação do tecido, Broussais fornece a Comte uma solução para o problema acerca da possibilidade de se comparar a saúde e a patologia, fazendo dessa uma espécie de experimento espontâneo daquela. Tal comparação é justificada porque normal e patológico não se distinguem quanto à natureza mas apenas em termos de quantidade.

Sendo assim, se a doença é uma variação quantitativa do normal, daí decorre, como nota Comte, que o estado fisiológico deve constituir o ponto de partida necessário para a determinação do patológico; reciprocamente, porém, a observação atenta dos estados patológicos pode fornecer novos dados para o incremento dos estudos científicos a respeito do organismo normal (ibidem, p. 176). Nesse sentido, vale notar, com Canguilhem, que o interesse da pesquisa patológica não é outro que o de enriquecer o conhecimento do normal:

\footnotetext{
No pensamento de Comte, o interesse se dirige do patológico para o normal, com o objetivo de determinar especulativamente as leis do normal, porque é como substituto de uma experimentação biológica frequentemente impraticável, sobretudo no homem, que a doença parece digna de estudos sistemáticos (2007, p. 14).
}

\footnotetext{
${ }^{19}$ Sobre a irritação ou inflamação como forma geral de inteligibilidade dos fenômenos patológicos, Foucault afirma que "esta ainda implicava uma conceituação abstrata: a universalidade que lhe permitia tudo explicar formava para o olhar posto sobre o organismo um meio de abstração" (FOUCAULT, 2004, p. 212). Era assim que pensavam, por exemplo, alguns médicos contemporâneos de Broussais, acusando-o de incorrer naquilo mesmo que ele tão fortemente criticava: o uso de conceitos abstratos na explicação médica. Contra eles, logo no capítulo primeiro, da primeira parte de De l'irritation et de la folie, o médico francês sublinha que "a palavra irritação relembra então um fato que todo mundo constatou e pode verificar novamente quando bem entender" (BROUSSAIS, 1986, p. 24, nota 1), de modo que "a palavra Irritação representa para os médicos a ação de irritantes, ou o estado das partes viventes irritadas. Chama-se irritantes todos os modificadores de nossa economia que exaltam a irritabilidade ou a sensibilidade dos tecidos vivos, e que elevam estes fenômenos acima do grau normal" (Ibidem, p. 23).
} 
Comte autoriza a aplicação desse método tanto ao "conjunto da série orgânica" (COMTE, ibidem, p. 177), quanto aos "diversos fenômenos do mesmo organismo" (ibidem, p. 178), inclusive àqueles que são mais delicados, como os fenômenos intelectuais e morais ${ }^{20}$, e que, por conta disso, seriam facilmente desnaturados pela experimentação direta.

Mas não são apenas as doenças que a biologia positiva explica a partir do princípio de Broussais. Também as anomalias ou monstruosidades consistem, segundo Comte, num "apêndice natural" (ibidem, p. 178) e "numa espécie de prolongamento universal" (ibidem, p. 179) da análise patológica, na medida em que se considera as organizações excepcionais, ou os casos de monstruosidade, como "verdadeiras doenças, cuja origem é somente mais antiga e menos conhecida, e a natureza ordinariamente mais incurável (...)" (ibidem, p. 179).

Sobre essas teses, Canguilhem não deixa de observar a ausência, ao longo da 40e. Leçon, de qualquer exemplo médico capaz de ilustrá-las, do que segue seu caráter eminentemente conceitual e abstrato (2007, p. 15, 22) - o que mudará radicalmente com Claude Bernard. Mas abstrato é mesmo uma das características definidoras da biologia positiva (COMTE, ibidem, p. 249). Daí o esforço comteano, reiterado em vários momentos do curso, para decantar uma ciência fisiológica especulativa e abstrata, o ramo mais elevado da árvore do conhecimento biológico, distante seja do ramo da biologia prática, do qual pende a medicina, seja do ramo da biologia concreta, no qual floresce a patologia (ibidem, p. 246$247)^{21}$.

Assim, enquanto ciência especulativa e abstrata, a biologia positiva deve se limitar "ao estudo essencial do estado normal, concebendo a análise patológica como um simples meio de

\footnotetext{
${ }^{20}$ É importante sublinhar que, contra a tradição cartesiana que concebia as faculdades superiores do homem como exteriores ao campo de investigação científica, tomando-as como objetos da especulação metafísica, Comte procura desenvolver uma teoria $\mathrm{eu}$ absolutamente positiva, cujo fundamento se encontraria sobretudo na frenologia. Para uma análise mais detalhada da constituição da teoria biológico-positiva do eu, cf. BENOIT, 1999, p. 276-324.

${ }^{21}$ Segundo Benoit, a biologia positiva divide-se em concreta e abstrata. "A biologia concreta é desenvolvida duplamente como (1) história natural (isto é, como realização de um 'quadro racional e direto do conjunto da existência da cada organismo'); e também enquanto (2) patologia (isto é, como 'exame sistemático das diversas alterações de que [o organismo] é susceptível, o que se constitui numa espécie de apêndice e de complemento de sua história'). Contudo, segundo Comte, não pode existir uma divisão interna acentuada na biologia abstrata ou especulativa; de qualquer modo, pode-se subdividi-la em: (1) estática (isto é, estudo da estrutura do organismo ou de sua composição ou 'biotomia'; e construção da hierarquia biológica ou 'biotaxia'); e (2) dinâmica ou 'bionomia', que não comporta subdivisões e é a fisiologia propriamente dita (CPP, TI, L. 40, p. 740 e ss.). Também seria importante lembrar que a biotomia, ou anatomia comparada, ou estática biológica, domina a classificação interna da biologia na medida em que, como veremos agora, fundamenta a própria fisiologia" (1999, p. 296-297, n. 27). Como uma análise mais minuciosa das relações entre fisiologia e anatomia na epistemologia comteana da biologia exigiria um trabalho específico, muito distante do que nos interessa neste momento, utilizaremos na presente dissertação anatomia e fisiologia como conceitos equivalentes, não apenas porque Comte os mobiliza diversas vezes sem estabelecer precisas distinções entre eles, seja porque a fisiologia só pode ser pensada a partir da anatomia comparada.
} 
exploração, como foi explicado" (ibidem, p. 247). Desse limite provém uma condição indispensável para a prática de qualquer tipo de investigação experimental: "conhecer, o mais completamente possível, segundo a observação propriamente dita, o verdadeiro estado normal do organismo correspondente e os verdadeiros limites de variação do qual ele é suscetível" (ibidem, p. 179, grifos nossos). Porém, e esta é a segunda observação crítica que Canguilhem dirige às teses comteanas, nessa exigência de se determinar previamente, pela via da observação pura, o estado normal:

\begin{abstract}
(...) uma grave lacuna se apresenta pelo fato que Comte não propõe nenhum critério permitindo reconhecer que um fenômeno é normal. É-se, então, levado a pensar que, sobre este ponto, ele se refere ao conceito usual de normal, estando dado que ele utiliza indiferentemente as noções de estado normal, de estado fisiológico e de estado natural $(2007$, p. 22$)$.
\end{abstract}

No limite, para caracterizar o estado normal, Comte é obrigado a recorrer a um valor, e não, como se esperaria, a um padrão de medida capaz de reduzir a diferença entre o normal e o patológico à homogeneidade: trata-se da ideia de que a condição necessária para o desenvolvimento normal da vida consiste na harmonia entre a organização vital e o seu meio. "De modo que, finalmente esclarecido pelo conceito de harmonia, o conceito de normal ou de fisiológico é reconduzido à um conceito qualitativo e polivalente, estético e moral mais ainda que científico" (ibidem, p. 23).

Contudo, sublinha Canguilhem, se é a Broussais que Comte recorre para afirmar a identidade entre os fenômenos normais e patológicos, é também a Broussais ${ }^{22}$ que devemos atribuir a inadequação do vocabulário comteano à intenção primeira de negar, ao estado mórbido, qualquer natureza própria (ibidem, p. 23).

Em primeiro lugar, Canguilhem observa que Broussais confunde a causa da doença, ou seja, o aumento de excitação tissular, com o efeito, ou seja, a própria doença (Ibidem, p. 24). Ora, objeta o filósofo, há casos em que a intensificação da excitação conduz a estados prazerosos até um certo momento, tornando-se depois desagradáveis ou mesmo patológicos. Nesse caso, o vivente experimenta dois estados qualitativamente diversos produzidos por uma

\footnotetext{
${ }^{22}$ Canguilhem observa, no entanto, que as incoerências teóricas em que Broussais incorreu são decorrentes da composição, sem uma atenção maior para com as respectivas implicações, do ensino de Bichat e de John Brown. Ao último, Broussais deve a compreensão de que a tese da identidade quantitativa do normal e do patológico implica na pesquisa de um método de medida responsável por identificar o estado fisiológico e calcular as suas variações; do primeiro, Broussais apreende que os métodos e o objeto da fisiologia diferem dos métodos e dos objetos das ciências físico-químicas, donde a desconfiança, que acometerá posteriormente Claude Bernard e o próprio Comte, a respeito do tratamento matemático dos fenômenos vitais (cf. CANGUILHEM, 2007, p. 26-30).
} 
mesma causa, o crescimento da excitação. Mas se Broussais confunde causa e efeito, é porque sua teoria mistura constantemente dois pontos de vista: o do doente, que experimenta a doença e é por ela experimentado, e o do médico, que, pela observação, toma o normal como um fato desprovido de qualquer referência ao sujeito que o vivencia.

Além disso, e segundamente, os conceitos de que se vale Broussais, tais como alteração, depravação, excesso e falta, são fortemente normativos, velando, sob termos aparentemente quantitativos, a referência a uma norma que apenas pode ser de ordem qualitativa, como comenta Canguilhem: "mais ainda do que se tratando de Comte, notar-se-á [em Broussais] a vagueza de noções de excesso e de falta, seu caráter qualitativo e normativo implícito, dificilmente dissimulado sob sua pretensão métrica" (Ibidem, p. 25). Pois, como indicara Canguilhem no início do curso do ano escolar de 1942-1943, se toda norma relaciona uma existência a um valor, e se os conceitos empregados pela fisiologia positiva comportam uma norma, então eles necessariamente se referem a um valor, contradizendo a afirmação de uma real homogeneidade entre o normal e o patológico:

É em relação a uma medida julgada válida e desejável - e, então, em relação a uma norma - que há excesso ou falta. Definir o anormal pelo excesso ou pela falta, é reconhecer o caráter normativo do estado dito normal. Esse estado normal ou fisiológico não é mais somente uma exposição detectável e explicável como um fato, é a manifestação de uma vinculação a qualquer valor (Ibidem, p. 25).

Como já vimos a propósito de Durkheim, a definição quantitativa das relações entre o normal e o patológico envolvia um conteúdo axiológico que, segundo Canguilhem afirmava, dependia de uma certa filosofia realista para a qual a norma numérica é expressão de uma perfeição essencial. Em Comte e Broussais, Canguilhem observa o mesmo procedimento. Sobre isso, Le Blanc é preciso na sua interpretação:

Broussais e Comte não podem negar a diferença qualitativa que os vitalistas admitiam, aos olhos de Canguilhem, entre o normal e o patológico, senão ao preço de uma nova diferença qualitativa não formulada como tal que esconde uma ontologia implícita da regularidade. Não chegando a fixar um sentido médico do normal, Comte e Broussais lhe substituem implicitamente um sentido ontológico que culmina numa definição do ser como regularidade (2005, p. 124).

Essa ontologia implícita da regularidade é aquela que aparece na forma do ideal de perfeição pressuposto por noções como harmonia, consenso, equilíbrio, regularidade, unidade. É o que Canguilhem explicita na definição de normal utilizada por Bégin, discípulo de Broussais: 
Quando Bégin define o estado normal como aquele em que 'os órgãos agem com toda a regularidade e uniformidade do qual são eles suscetíveis nós não podemos hesitar em reconhecer que um ideal de perfeição, apesar do horror que inspirava a Broussais toda ontologia, paira sobre essa tentativa de definição positiva (CANGUILHEM, 2007, p. 25-26).

Do mesmo modo que na sociologia de Durkheim, na biologia positiva de Comte o fato da normalidade empiricamente observável se resolve numa ontologia da regularidade para a qual o valor supremo almejado por cada vivente como sua finalidade última é o consenso ou a harmonia. Por conta disso, salienta Braunstein, “a intuição 'romântica' originária, emprestada de Bichat, da vida como luta ininterrupta, é recoberta pela preocupação de equilíbrio entre interior e o exterior, entre o organismo e meio. Assim fazendo, Comte omite o fato de que a vida é 'emergência', imprevisibilidade, 'invenção' de formas radicalmente novas (2008, p. 106). Não é demais afirmarmos que há, portanto, uma ontologia da vida como regularidade que sustenta a pretensão comteana de explicar a diferença entre os valores vitais em termos somente quantitativos.

Ao estender para a explicação dos fenômenos sociais o mesmo princípio de inteligibilidade dos fatos biológicos fornecido por Broussais, Comte importa também a para ciência positiva aquela ontologia da regularidade que lhe servia para fundar o conceito de normalidade vital. Desse modo, Canguilhem notará alguns anos após a publicação do Essai que Comte 'buscou numa noção de origem biológica que era a noção de 'consensus', ou simpatia das partes do organismo entre elas, uma noção que ele importava para o terreno sociológico" (1955, p. 66). Não é, portanto, injustificável pensarmos que, se Durkheim, como sublinha Canguilhem, adotou de Comte, assim como de Claude Bernard, uma concepção quantitativa das relações entre saúde e doença, então é provável que essa ontologia da regularidade que sustenta na filosofia comteana tal concepção tenha se incorporado também à sociologia durkheimeana, convertendo-se numa ontologia social de origem biológica.

Para que essa ideia de sociedade identificada ao organismo e pensada a partir de uma ontologia biológica da regularidade seja criticada, Canguilhem terá antes que elaborar uma nova filosofia da vida para a qual a diferença qualitativa entre os fenômenos normais e patológicos será recuperada a partir da subjetividade vivente.

Mas Comte não foi o único a sustentar na França a tese da identidade essencial entre fenômenos normais e patológicos. Inclusive, a ausência de exemplos médicos, a carência de precisão científica nas discussões sobre os fenômenos biológicos, o vocabulário oscilando entre o quantitativo e o qualitativo revelam, para Canguilhem, o fracasso do projeto positivista 
de fundar uma terapêutica e uma patologia objetivas, orientadas por uma fisiologia especulativa e abstrata:

\begin{abstract}
A ambição de tornar a patologia e, por conseguinte, a terapêutica integralmente científicas, fazendo-as proceder simplesmente de uma fisiologia previamente instituída, apenas teria sentido se uma definição puramente objetiva pudesse ser dada do normal como de um fato, se, além disso, fosse possível traduzir toda diferença entre o estado normal e o estado patológico numa linguagem da quantidade, porque só a quantidade pode dar conta, ao mesmo tempo, da homogeneidade e da variação. (...) Mas de toda forma deve-se constatar que nem Broussais, nem Comte, realizaram as duas exigências que parecem inseparáveis das tentativas às quais eles ligaram suas normas (Ibidem, p. 26).
\end{abstract}

Esse mesmo projeto teórico de estabelecer uma patologia objetiva fundada sobre uma fisiologia científica será continuado por Claude Bernard, mas num sentido diferente daquele intentado primeiro por Broussais, depois por Comte.

\title{
O nascimento da fisiologia científica em Claude Bernard
}

Podemos distinguir dois momentos da leitura que Canguilhem realiza de Claude Bernard ao longo da sua trajetória intelectual. Nesta dissertação, dado o recorte cronológico que ela assume, interessa-nos sobretudo seguir as indicações interpretativas do primeiro momento, do qual as páginas do Essai dedicadas ao médico francês são as mais representativas. $\mathrm{O}$ segundo momento, conforme explicita o próprio autor na introdução às suas Nouvelles Réflexions, é posterior à publicação dos Principes de médecine expérimentale, em $1947^{23}$ :

\begin{abstract}
A isso se acrescentava que as novas leituras de Claude Bernard, estimuladas e esclarecidas pela publicação, em 1947, dos Principes de médecine expérimentale, deveriam atenuar o rigor do julgamento que eu fizera de início a respeito das relações da fisiologia e da patologia e me tornaram mais sensível ao fato de que $\mathrm{Cl}$. Bernard não desconheceu a obrigação para a experiência clínica de preceder a experimentação de laboratório (2007, p. 172).
\end{abstract}

Se Canguilhem é capaz de reconhecer um deslocamento de prioridade da ciência para a clínica na obra bernardiana é porque, ao longo da sua trajetória intelectual, o cientista se

\footnotetext{
${ }^{23}$ Acreditamos que os textos mais representativos deste segundo momento estão publicados nos Études d'histoire et de philosophie des sciences: L'idée de médicine experimentale selon Cl. Bernard, Théorie et technique de l'expérimentation chez Claude Bernard, Claude Bernard et Bichat, L'évolution du concept de méthode de Claude Bernard à Gaston Bachelard e Le concept et la vie.
} 
torna paulatinamente mais permeável às hipóteses vitalistas ${ }^{24}$. De fato, a interpretação de Canguilhem oscila entre um retrato materialista e determinista da medicina experimental de Claude Bernard, exposto no primeiro momento, e um outro, de contorno vitalista, interessado nos debates metafísicos da obra bernardiana sobre o problema da organização da matéria vivente. Porém, essa oscilação que encontramos em Canguilhem é, para nós, consequência do que Pichot designa como a "indecisão epistemológica",25 de Claude Bernard (1993, p. 696): "Nos fatos, para além das declarações de intenções que não são respeitadas, a biologia bernardiana se caracteriza por sua incapacidade de sair do dilema materialismo-vitalismo (para retomar seus termos, supondo que eles são corretos)" (Ibidem, p. 712). Contudo, tal indecisão epistemológica se opõe à certeza metodológica de que só tem lugar no campo da ciência fisiológica aqueles objetos que se prestam a uma pesquisa experimental das suas condições físico-químicas. Daí, a divisão em duas partes da biologia bernardiana, que Pichot assim resume:

uma parte que se poderia qualificar de biologia materialista e experimental (que não recorre à finalidade), e uma outra que seria mais vitalista e que, pelo fato de que ela escapa à experimentação, é concebida como proveniente da metafísica (é essa metafísica que regula a questão da finalidade) (Ibidem, p. 702).

Contudo, dessas duas partes da biologia bernardiana, apenas a primeira é relevante para esta pesquisa. Isso porque, em primeiro lugar, a parte metafísica das investigações de Claude Bernard não encontrou tanta ressonância no meio científico da época quanto a sua fisiologia, de modo que somos levados a admitir que Canguilhem se refere a essa última ao afirmar que a sociologia de Durkheim pretendia fundar a validade contestada dos seus conceitos sobre a validade provada dos conceitos fisiológicos correspondentes (1942-1943, p. 48); em segundo lugar, porque, como dissemos, tanto no Essai quanto nos textos e cursos de

\footnotetext{
${ }^{24}$ Vale notar que, entre os comentadores de Claude Bernard, Canguilhem é reconhecido por ter enfatizado as tendências vitalistas na obra bernardiana, aspecto que tem sido "mais frequentemente (senão totalmente) ignorado em favor de uma visão mais voltada para o futuro, positivista, que enfatiza o experimentalismo e o reducionismo" (SEBASTIAN, 2007, p. 498).

${ }^{25}$ A indecisão bernardiana já fora notada por seus colaboradores mais próximos, como atesta a citação seguinte extraída de uma homenagem realizada no ano da morte do cientista (1876) por Henri Beaunis, na Faculté de Médecine, de Nancy: "Claude Bernard, en effect, se trouva soumis alors à deux influences contraires, d'une part cette imagination native, audacieuse et créatrice qui entraînait vers la théorie, vers la généralisation, vers l'hypothèse, et d'autre part, cette influence de Magendie, froid, sceptique, raillant l'idéal et n'acceptant pas le fait. De là cette dualité intellectuelle si curieuse à observer dans les oeuvres de Claude Bernard et qui me paraîtetre le trait psychologique et la clef de son charactère. Il y a en lui deux hommes, l'auteur des Leçons de physiologie experimentale et l'auteur des Leçons sur les phénomènes de la vie, le chercheur du Collège de France et le généralisateur du Muséum.” (apud SEBASTIAN, 2007, p. 498).
} 
Canguilhem anteriores à 1947, a fisiologia bernardiana é enfocada principalmente no seu aspecto materialista.

Conforme o Essai, Claude Bernard partilhava com o positivismo ${ }^{26}$ comteano da ideia de que a prática deve ser orientada pela teoria, o que implicava, no contexto da medicina, na consolidação de uma ciência fisiológica capaz de dirigir totalmente a terapêutica racional. Contudo, como vimos acima, a realização dessa tarefa exigia que dois problemas fossem solucionados: em primeiro lugar, que "uma definição puramente objetiva pudesse ser dada do normal como de um fato" e, além disso, que "fosse possível traduzir toda diferença entre o estado normal e o estado patológico numa linguagem da quantidade, porque só a quantidade pode dar conta, ao mesmo tempo, da homogeneidade e da variação" (CANGUILHEM, 2007, 26).

A medicina de Broussais, assim como a biologia positiva de Comte, não lograram solucionar tais problemas na medida em que, segundo Canguilhem, faziam intervir na definição dos fenômenos normais critérios não apenas quantitativos, mas explicitamente qualitativos, como, por exemplo, o de harmonia entre vivente e meio, vinculando-se a uma ontologia da regularidade que permaneceu latente. Claude Bernard procurará outra via, menos especulativa $^{27}$, conferindo à tese da identidade entre os fenômenos normais e patológicos “argumentos controláveis, protocolos de experiência e, sobretudo, métodos de quantificação de conceitos fisiológicos" (Ibidem, p. 39).

Para Claude Bernard, a norma fisiológica seria então encontrada ao termo de um processo de experimentação, comparação e mensuração. É por essa via que o médico francês chega a fornecer um conteúdo determinado a diferentes normas orgânicas, estabelecendo, por exemplo, que o limite normal de glicemia é de 3 à $4 \%$, para além do qual os rins não conseguem conter a passagem da glicose excedente no sangue para a urina, resultando na glicosuria, sintoma maior do diabetes. Claude Bernard então conclui:

\footnotetext{
Há apenas uma glicemia, ela é constante, permanente, seja durante o diabetes, seja fora desse estado mórbido. Só que ela tem graus: a glicemia abaixo de 3 à $4 \%$ não conduz à glicosuria; mas acima a glicosuria se produz...A passagem do estado normal ao estado patológico é impossível de ser apreendida e não há nenhuma questão melhor do que o diabetes para mostrar a fusão da fisiologia com a patologia" (apud Ibidem, p. 36, grifos nossos).
}

\footnotetext{
${ }^{26}$ Sobre as relações de Claude Bernard com o positivismo comteano, em particular no que diz respeito ao problema da história das ciências, conferir: PETIT, Annie. D'Auguste Comte à Claude Bernard, un positivisme déplacé. Romantisme, 1978, n. 21-22. Le positivisme. p. 45-62.

27 Para uma análise detalhada das divergências entre Comte e Claude Bernard com relação ao papel da observação e da experimentação no estudo dos fenômenos vitais, conferir: NORMANDIN, 2007, p. 520-523.
} 
Fusão que seria dependente da recusa em reconhecer no fenômeno patológico a instauração de uma nova norma orgânica. O esforço de Claude Bernard em sustentar essa afirmação é tal que ele chega mesmo a defender, não sem alguma hesitação, a presença no estado normal de um "tipo de glicosuria fugidia que estabelece aqui, como em todas as situações, uma passagem insensível e inapreensível entre o estado fisiológico e o estado patológico" (apud Ibidem, p. 35). Contudo, mesmo que não se possa afirmar com total segurança o caráter normal da glicosuria ${ }^{28}$, o argumento de que a urina com açúcar é diferente qualitativamente da urina sem açúcar não é suficiente para colocar em questão a tese da fusão da fisiologia com a patologia, pois, para Claude Bernard, desde que o médico assuma o ponto de vista dos mecanismos funcionais isolados, e não dos efeitos sintomáticos, nenhuma norma biológica inédita resultará da doença. Como resume Canguilhem:

\begin{abstract}
O estado patológico identificado com o seu principal sintoma é, relativamente ao estado fisiológico, uma qualidade nova. Mas se, considerando a urina como um produto da secreção renal, o pensamento do médico se orienta em direção ao rim e às relações do filtro renal com a composição do sangue, ele considera a glicosuria o excesso da glicemia ultrapassando um limite. A glicose que transborda o limite é qualitativamente a mesma que a glicose normalmente retida pelo limite. A única diferença é, com efeito, a quantidade (Ibidem, p. 42, grifos nossos).
\end{abstract}

Porém, para que seja possível eliminar definitivamente da noção de patologia qualquer vestígio de uma qualidade nova, faz-se necessário que o médico divida a doença numa série de mecanismos e num feixe de relações isoladas, cuja explicação se dá unicamente pelo recurso às leis físico-químicas ${ }^{29}$. No limite, a análise dos fenômenos mórbidos levaria o cientista a encontrar, por exemplo, "leis físicas dos equilíbrios de membrana, leis de concentração de soluções, reação de química orgânica etc" (CANGUILHEM, 2007, p. 43).

Certamente, Claude Bernard chega a reconhecer que essas leis não são capazes de fornecer uma explicação exaustiva da vida, na medida em que certos processos orgânicos, as sínteses morfológicas, responsáveis pela reunião da matéria viva numa forma ou figura

\footnotetext{
${ }^{28}$ Claude Bernard estava ciente das dificuldades teóricas que essa hipótese encontrava na comunidade científica da época: "en réalité, $\mathrm{Cl}$. Bernard ne démontre pas effectivement ce qu'il avance. A la seizième leçon, après avoir confronté les opinions des physiologistes qui nient la présence constante de sucre dans l'urine normale, aprés avoir montrè la difficulté des expériences et de leur contrôle, $\mathrm{Cl}$. Bernard ajoute que dans l'urine normale d'un animal nourri de substances azotées et privé de sucres et de féculents il n'a jamais réussi à déceler la présence des plus faibles quantités de sucre, mais qu'il em va tout autrement d'un animal nourri de sucres ou de féculents en excès" (CANGUILHEM, 2007, p. 35).

${ }^{29}$ Se a fisiologia científica deve analisar os fenômenos orgânicos até chegar a mecanismos locais isolados, é porque esses, convertidos em processos físico-químicos elementares, podem ser explicados pelas leis físicas, enquanto que os fenômenos da organização, por suporem uma finalidade interna a guiá-los, dizem respeito a hipóteses metafísicas que não são passíveis de experimentação.
} 
determinada, independem da composição química e das forças físicas ${ }^{30}$. Contudo, ainda que a posição do cientista francês varie quanto a importância das sínteses morfológicas na economia da vida $^{31}$, ele nunca deixará de afirmar que à fisiologia cabe apenas estudar experimentalmente os organismos segundo o seu aspecto material, aqueles submetidos ao determinismo das leis físico-químicas, sendo tarefa da botânica e da zoologia classificá-los de acordo com as suas formas, que não podem ser objeto de experimentações, somente da contemplação (CLAUDE BERNARD, 1966, p. 342).

Com isso, o médico francês tende a "incorporar a patologia nas ciências da vida, a fundar a patologia sobre as bases da lei e do determinismo" (CANGUILHEM, 2007, p. 142) descobertos pela investigação experimental fisiológica. Está assegurada assim a objetividade da patologia pela redução dos processos orgânicos mórbidos a fenômenos parciais, cujas relações são traduzíveis integralmente em termos de leis físico-químicas homogêneas àquelas que regulam a matéria. Tal redução de fenômenos vitais complexos aos seus elementos constituintes permite ao fisiologista eliminar por análise a subjetividade vivente implicada nas sínteses biológicas, transformando-as em puros fatos passíveis de serem submetidos aos métodos oriundos das ciências físicas. O primado do fato sobre o valor, que Canguilhem identificava na consolidação das ciências humanas, é o que organiza o campo de inteligibilidade dos estados fisiológicos na ciência médica de Claude Bernard. Nas Leçons sur le chaleur animale, ao combater os que admitem uma diferença qualitativa entre os mecanismos e produtos das funções vitais sãs e patológicas, Claude Bernard afirma que não há variações de natureza nas propriedades ${ }^{32}$ físico-químicas, seja no interior do organismo

\footnotetext{
30 "La morphologie, comme nous le verrons, paraît gouvernée par des lois absolument indépendantes de celles qui règlent les manifestations vitales essentielles du protoplasma. Elle suppose cette matière avec ses propriétés mais elle l'utilise d'un façon tout à fait indépendant et suivant des conditions qui n'y sont pas nécessairement contenues" (CLAUDE BERNARD, 1966, p. 296-297).

${ }^{31}$ A oscilação quanto ao papel dos processos de síntese morfológica na determinação da essência dos fenômenos vitais fornece um outro exemplo da indecisão epistemológica de Claude Bernard. Com efeito, em alguns trechos das Leçons sur les phénomènes de la vie, o cientista afirma que a essência da vida não está na forma, mas na composição química da matéria viva: "Em seu grau mais simples (aliás, realizado isoladamente na natureza, ou não), despida dos acessórios que a mascaram na maior parte dos seres, a vida, contrariamente ao pensamento de Aristóteles, é independente de toda forma específica. Ela reside numa substância definida por sua composição e não por sua figura, o protoplasma (CLAUDE BERNARD, 1966, p. 350-351). Porém, Claude Bernard vai se contradizer em outras passagens, nas quais afirma que o que caracteriza o vivente é a sua forma ou ideia diretriz e não a matéria orgânica: “(...) mas o que é essencialmente do domínio da vida e que não pertence nem à química, nem à física, nem a outra coisa, é a ideia diretriz dessa evolução vital” (1966b, p. 142). Conforme defendemos, essa "indecisão" se reflete em Canguilhem que, no Essai, identifica Claude Bernard com a primeira afirmação, enquanto que no artigo Le concept et la vie, por exemplo, o cientista francês é vinculado mais propriamente à segunda afirmação.

${ }^{32}$ Claude Bernard distingue as propriedades dos fenômenos. Para o cientista, os fenômenos podem ser simples ou complexos. Um fenômeno simples não é passível de ser analisado em fatos mais simples, sendo, portanto, irredutível. Já os fenômenos complexos são os que podem ser reduzidos a fatos mais simples. Os fenômenos vitais são fenômenos complexos passíveis de redução a um conjunto de fatos simples, que são precisamente as
} 
seja fora dele, seja no estado saudável seja no mórbido. Nessa proposição, Canguilhem observa que a identificação entre o normal e o patológico é indissociável do pressuposto da identidade entre os fenômenos orgânicos e inorgânicos ${ }^{33}$, entre a vida e a morte:

\begin{abstract}
A ideia da continuidade entre o normal e o patológico está ela mesma em continuidade com a ideia da continuidade entre a vida e a morte, entre a matéria orgânica e a matéria inerte. Cl. Bernard tem incontestavelmente o mérito de ter negado as oposições até então admitidas entre o mineral e o orgânico, entre o vegetal e o animal, de ter afirmado a onivalência do postulado determinista e a identidade material de todos os fenômenos físico-químicos qualquer que seja a sede e qualquer que seja a sua forma (Ibidem, p. 37).
\end{abstract}

Recusar a existência de diferenças entre os diversos gêneros de fenômenos é uma maneira de professar a "fé na validade universal do postulado determinista". Se Claude Bernard pode ser considerado o introdutor do termo "determinismo" na língua científica francesa (Ibidem, 64), a ideia que dele faz o fisiologista deve ser atribuída a Laplace, para quem as leis físico-químicas, uma vez estabelecidas, não podem ser alteradas e se prestam a uma integral extensão para toda a realidade, sem exceção. Dessa afirmação, extrai-se a definição bernardiana do determinismo fisiológico:

[O determinismo fisiológico] consiste neste princípio que cada fenômeno vital, como cada fenômeno físico, é invariavelmente determinado por condições físico-

propriedades físico-químicas da matéria. Contra os vitalistas, que afirmavam a existência de propriedades vitais especiais, Claude Bernard defende que as únicas propriedades - fatos simples irredutíveis - são as da matéria. Porque, diz Dutra, "o avanço da fisiologia permite mostrar que os fenômenos vitais são complexos de propriedades físicas que o vitalismo, para Bernard, foi deixado para trás na história das ciências” (2001, p. 103).

${ }^{33}$ Canguilhem observa, porém, que em alguns momentos Claude Bernard sugere uma concepção mais nuançada sobre as relações entre o orgânico e o inorgânico, de maneira que o reconhecimento da continuidade entre eles não impede o médico de reconhecer também a originalidade dos fenômenos vitais: "nous croyons avec Lavoisier que les êtres vivants sont tributaires des lois générales de la nature et que leurs manifestations sont des expressions physiques et chimiques. Mais loin de voir, comme les physiciens et les chimistes, le type des actions vitales dans les phénomènes du monde inanimé, nous professons, au contraire, que l'expression est particulière, que le mécanisme est spécial, que l'agent est spécifique, quoique le résultat soit identique. Pas un phénomène chimique ne s'accomplit dans le corps comme en dehors de lui" (BERNARD, CLAUDE apud CANGUILHEM, 2007, p. 39, grifos nossos). Nos Cahiers de notes, Claude Bernard chega mesmo a afirmar que a fisiologia deve nutrir uma desconfiança acerca dos princípios e leis provenientes das ciências físico-químicas (cf. CANGUILHEM, 1975b, p. 145).

Essa desconfiança não apareceria, segundo Claude Bernard, na comparação que Lavoisier estabelece entre a combustão química de um pedaço de madeira e a respiração animal. Para o médico francês, essa identificação não leva em conta a especificidade das reações físico-químicas que ocorrem nos seres vivos, que, no caso da respiração, transforma-a num tipo de combustão indireta, cuja realização depende da intervenção de agentes mediadores: "ils [Lavoisier e os químicos que o seguiram] ont assimilé les processus chimiques qui se font dans l'organisme à une oxydation directe, à une fixation d'ocygène sur le carbone des tissus. En un mot, ils ont cru que la combustion organique avait pour type la combustion qui se fait en dehors des êtres vivants dans nos foyers dans nos laboratoires. Tout au contraire, il n'y a peut-être pas dans l'organisme un seul de ces phénomènes de prétendue combustion qui se fasse par fixation directe d'oxygène. Tous empruntent le ministère d'agents spéciaux, des ferments par exemple" (CLAUDE BERNARD, 1966, p. 166). 
químicas que, permitindo-lhe ou impedindo-lhe de aparecer, tornam-se as condições ou as causas materiais imediatas ou próximas (CLAUDE BERNARD, 1966, p. 56).

Sem pressupor tal determinismo físico-químico rigoroso, a ciência experimental, nela inclusas a biologia e a medicina, não seria possível ${ }^{34}$. Por isso que não se pode negar que os fenômenos dos quais se ocupam as ciências da vida tenham "suas condições determinadas e tão rigorosamente necessárias quanto o fenômeno mais simples. É precisamente nesta determinação de condições que reside a ciência; por conseguinte, aquele que nega o determinismo, nega a ciência” (CLAUDE BERNARD, 1947, p. 224).

A profissão de fé no determinismo implica na renúncia vigorosa da indeterminação: "a ciência repele o indeterminado (...)" (CLAUDE BERNARD apud CANGUILHEM, 2007, p. 64). Daí porque todas as suas figuras: o mal ${ }^{35}$, a qualidade, a heterogeneidade, a distinção, só serão admitidas como ilusões advindas da nossa ignorância a respeito daquilo que as determina:

\begin{abstract}
Quanto às exceções, nós sabemos igualmente que não existem e que elas não podem ser senão a marca da nossa ignorância. Um fenômeno é sempre idêntico a ele mesmo, nas mesmas circunstâncias. Quando nós vemos um fenômeno se apresentar com aparências diferentes, nós devemos concluir necessariamente que as circunstâncias não são as mesmas (CLAUDE BERNARD, 1947, p. 224).
\end{abstract}

Para o pensamento bernardiano, que "acredita na legalidade fundamental da vida, análoga àquela da matéria (...)" (CANGUILHEM, 1975, p. 158), as exceções, como, por exemplo, as doenças em relação à normalidade fisiológica, só podem ser um obstáculo que a ciência médica deve se esforçar para ultrapassar por meio de uma terapêutica informada sobre as condições que possibilitaram o seu aparecimento. Ultrapassamento que se dará pela afirmação da homogeneidade da exceção em relação ao termo normal, da patologia em relação à saúde, o que implica na redução da qualidade a "um padrão de objetividade fundado em dispositivos de mensuração, de redução quantitativa e de abstração a um padrão geral de cálculo" (SAFATLE, 2011, p. 17). Assim, a fisiologia bernardiana reitera sua intenção de

\footnotetext{
34 Claude Bernard não hesita em afirmar que "racionalmente, é possível submeter à experimentação os fenômenos dos seres vivos como aqueles dos corpos brutos, porque, em uns e em outros, há um determinismo necessário e absoluto nas condições dos fenômenos" (1947, p. 186).

35 Para Canguilhem, a exclusão do mal do campo da medicina representa uma das maneiras pelas quais a fisiologia oitocentista procura satisfazer as expectativas gerais de racionalidade do momento histórico em que se constituíram. Assim, "a convicção do otimismo racionalista de que não há realidade do mal” (CANGUILHEM, 2007, p. 61) implica na recusa de uma concepção ontológica de doença, típica do vitalismo e do animismo do setecentos, para a qual os estados patológicos seriam causados pela ação de um ente maligno atuando no organismo. Em sentido contrário, a fisiologia científica insistia no monismo médico baseado na afirmação da identidade entre estados normais e patológicos.
} 
subordinar os estudos dos fenômenos vitais aos protocolos de racionalidade das ciências físico-químicas:

\begin{abstract}
Reduzir a diferença entre um homem são e um diabético a uma diferença quantitativa do teor de glicose do meio interior, delegar a um limite renal, simplesmente concebido como uma diferença quantitativa de nível, a incumbência de discernir quem é diabético e quem não é, é obedecer ao espírito das ciências físicas que não podem explicar os fenômenos, submetendo-os a leis, senão por sua redução a uma medida comum. Para fazer entre os termos nas relações de composição e de dependência, convém, de início, obter a homogeneidade desses termos (CANGUILHEM, 2007, p. 66, grifos nossos).
\end{abstract}

As ciências da vida teriam, portanto, assumido das ciências naturais a ordem de unificação pela quantidade, por meio da qual a diversidade das qualidades biológicas se reduz à homogeneidade de um normal definido em termos quantitativos.

Ao longo deste capítulo, acompanhamos a primeira parte do Essai na sua tentativa de explicar como o dogma da identificação entre o normal, a saúde e a média ou a regularidade se constituiu na quadro das ciências da vida, particularmente na filosofia positiva de Comte e na fisiologia experimental de Claude Bernard. Esses dois autores, observadas as profundas diferenças de método que os separam, procuraram garantir a objetividade dos conceitos médicos de normal e patológico pela redução do primeiro a uma medida, a média ou a frequência, da qual o segundo seria apenas uma variação quantitativa. Com isso, o diagnóstico médico das patologias vitais se emancipa da clínica, em que a subjetividade do vivente enfermo fornecia a norma de apreciação dos seus estados vitais, para se vincular à ciência, na qual o julgamento científico assume como norma uma medida objetiva em relação à qual os fenômenos desviantes são tidos por anormais ou patológicos. Daí porque o conhecimento do estado normal se tornou condição de possibilidade para a identificação das patologias, dado que essas seriam idênticas em natureza ao primeiro, exceto pela falta ou pelo acréscimo de algo.

Redução das diferenças qualitativas à forma da variação quantitativa, prioridade do conhecimento do normal sobre o conhecimento do patológico, subordinação dos julgamentos subjetivos a uma medida objetivamente definida em termos numéricos: tais são as teses fundamentais que se revelaram anteriormente na análise canguilhemeana da sociologia de Durkheim. A persistência de tais protocolos de inteligibilidade dos fenômenos vitais no campo da teoria social durkheimeana é o saldo maior da assimilação por Durkheim dos conceitos médicos de normal e patológico, importados da biologia positiva de Comte e da 
fisiologia de Claude Bernard. Nesse sentido, lembremos mais uma vez desta observação epistemológica central de Canguilhem:

\begin{abstract}
No fundo, o que se deve reprovar a Durkheim é de ter adotado, sem crítica, os conceitos fisiológicos clássicos, do fim do século XIX e desde Comte e Claude Bernard, conservando o problema do normal e do patológico, é de ter admitido como um dogma que 'fisiológico' equivale ao mesmo tempo a 'são' e a 'média'. Ora, é precisamente este dogma que deve ser colocado em questão (1942-1943, p. 50).
\end{abstract}

O questionamento desse dogma, com as consequências que dele se podem extrair, será a tarefa fundamental da segunda parte do Essai, na qual Canguilhem formulará sua concepção de vida como poder criador de novas normas biológicas. Porém, se o núcleo teórico da filosofia canguilhemeana da vida encontra-se naquela parte do Essai, é necessário mostrar que sua gênese remonta aos textos canguilhemeanos, do final da década de 1930, sobre a relação entre técnica e ciência. Eles serão o ponto de partida da segunda parte desta dissertação, no qual se tratará de acompanhar o desenvolvimento da filosofia da vida de Canguilhem até a formulação do conceito de normatividade vital, nos anos 1940, mostrando, por conseguinte, de que maneira esse conceito estabelece o horizonte de crítica à teoria médica da identificação essencial entre o normal e o patológico. 


\section{Parte II - Normatividade vital: por uma filosofia negativa da vida}

Ao avaliar as implicações da teoria médica da identificação essencial entre o normal e o patológico, Canguilhem procura estabelecer as relações entre essa teoria e as “(...) exigências e postulados intelectuais do momento histórico e cultural no qual ela foi formulada" (2007, p. 61). Desde o início do Essai, o filósofo insiste que o surgimento de uma nova concepção de doença visava satisfazer a necessidade de intervenção técnica capaz de controlar a natureza:

\footnotetext{
Mas numa concepção que admite e espera que o homem possa forçar a natureza e dobrá-la a suas intenções normativas, a alteração qualitativa separando o normal do patológico era dificilmente sustentável. Não se repetia desde Bacon que apenas se comanda a natureza obedecendo-a? Comandar a doença é conhecer suas relações com o estado normal que o homem vivente - e amante da vida - deseja restaurar. Donde a necessidade teórica, mas com prazo técnico diferido, de fundar uma patologia científica ligando-a à fisiologia (Ibidem, p. 13).
}

De fato, as duas concepções qualitativas de doença entre as quais o pensamento médico oscilava, a ontológica, para qual a enfermidade decorria da presença de um ente patogênico no corpo do vivente, e a dinâmica, segundo a qual a doença era resultado de um desequilíbrio no organismo em sua totalidade, depositavam suas esperanças de cura nas reações hedônicas e terapêuticas da própria natureza. Nesse contexto, o papel da técnica médica se limitava a imitar, no sentido de prolongar, a ação médica espontânea da natureza, a chamada vix medicatrix naturae. Evidentemente, conclui Canguilhem, "uma tal técnica é também um otimismo, mas aqui o otimismo concerne ao sentido da natureza e não ao efeito da técnica humana" (Ibidem, p. 13).

Para que a técnica médica se autonomizasse da espontaneidade terapêutica da natureza, foi necessário eliminar a oposição dinâmica entre normalidade e patologia, reduzindo-a somente a uma diferença quantitativa. Tratava-se, assim, de negar à doença uma existência portadora de outras normas do que aquela do normal: "A convicção de poder cientificamente reestabelecer o normal é tal que ela termina por anular o patológico. A doença não é mais objeto de angústia para o homem saudável, ela se tornou objeto de estudo para o teórico da saúde" (Ibidem, p. 14).

Desse modo, o patológico deixa de ser algo da ordem de uma experiência subjetiva opaca aos métodos científicos para se converter num objeto transparente ao conhecimento médico que dele pretende se apropriar. Garantir essa transparência era condição necessária 
para que a ciência se tornasse capaz de informar e orientar a técnica terapêutica no reestabelecimento da saúde. Assim, se a identificação essencial entre o normal e o patológico responde à exigência de desvinculação entre natureza e técnica, ela implica, por outro lado, na subordinação dessa última ao saber científico que lhe precede. Em tal subordinação, Canguilhem diagnostica outro ponto de convergência entre a teoria médica da identidade entre saúde e doença e os postulados intelectuais da época, que se resumem na celebre divisa positivista conhecer para prever, prever para agir: “(...) a teoria em questão traduz a convicção humanista que a ação do homem sobre o meio e sobre ele mesmo pode e deve se tornar inteiramente transparente ao conhecimento do meio e do homem, devendo ser somente a aplicação da ciência previamente instituída" (Ibidem, p. 62).

Não é por acaso que tanto Comte quanto Claude Bernard afirmavam a prioridade do conhecimento do normal para o diagnóstico e cura do patológico. Afinal, para eles era impossível uma terapêutica eficaz sem que de antemão o médico recebesse da fisiologia a medida das constantes normais que se deveria reestabelecer no enfermo. Quanto a isso, Claude Bernard é bastante claro ao declarar que:

A ciência se estabelecendo apenas pela via da comparação, o conhecimento do estado patológico ou anormal não poderia ser obtido sem o conhecimento do estado normal, da mesma forma que a ação terapêutica de agentes anormais ou medicamentos sobre o organismo não poderia ser compreendida cientificamente sem o estudo prévio da ação fisiológica dos agentes normais que mantém os fenômenos da vida $(1966$, p. 26).

Como não poderia deixar de ser, a assimilação na sociologia durkheimeana das teses fisiológicas sobre as relações entre o normal e o patológico implicou, também, na assunção da ideia de que a arte sociológica, que Durkheim identifica com a técnica de reestabelecimento do normal social, deve subordinar aos fins prescritos pelo conhecimento sociológico, que é o único a poder distinguir na diversidade dos fenômenos socais aqueles que são normais e os que são anormais.

Retornamos assim ao problema do primado do fato sobre o valor. Com efeito, se a ciência é conhecimento dos fatos, e se a ela cabe orientar a técnica na cura das patologias vitais e sociais, é porque esses fatos exprimem pela sua frequência ou generalidade o único ideal normativo ao qual se deve adequar os fenômenos desviantes. Nesse sentido, a cura só pode significar recuperação ou reestabelecimento de um certo valor normal definido em termos quantitativos. 
Assim, as relações entre técnica e ciência não é um problema menor no interior do projeto filosófico canguilhemeano de afirmação da supremacia do valor sobre o fato, na medida em que ele envolve a questão do estatuto da criação e seu poder de transformação do mundo dos fatos. Se, como veremos a seguir, a vida será definida por Canguilhem em termos de criação de normas, em oposição à concepção cientifica da fisiologia e biologia oitocentistas, não é de se estranhar que sua filosofia da vida comece a se esboçar justamente a partir de uma reflexão sobre a técnica. Com isso, estamos de acordo com Cammelli para quem: "é se colocando a questão radical de 'o que é a técnica?, 'o que é a criação?', 'o que é a invenção?', que Canguilhem vai se interessar pela vida como forma de técnica" (CAMMELLI, 2010).

Esse movimento é claro no primeiro texto que Canguilhem dedica exclusivamente a discutir o fenômeno da técnica: Descartes et la technique, de 1937. Inicialmente interessado no problema da relação entre julgamento técnico e julgamento científico em Descartes, o artigo se encerra apontando para o enraizamento da técnica no vivente, tema que será explorado, no ano seguinte, no texto Activité technique et création.

\section{Da técnica à vida}

Segundo Canguilhem, a reflexão cartesiana sobre a técnica tornou-se possível a partir de uma conversão moral. Conversão cuja trajetória se desenha exemplarmente entre o terceiro e o sexto capítulos do Discours de la Méthode.

A terceira máxima que constitui a "moral provisória" (DESCARTES, 1983, p. 41), na qual Descartes se abriga enquanto reconstrói o edifício da ciência, postula um certo tipo de "resignação estoica" (CANGUILHEM, 1996, p. 94) ante àquilo que escapa ao poder do homem:

\footnotetext{
Minha terceira máxima era a de procurar sempre antes vencer a mim próprio do que ao destino e de antes modificar os meus desejos do que a ordem do mundo (...); e que fazendo, como se diz, da necessidade virtude, não desejaremos mais estar sãos, estando doentes, ou estar livres, estando presos, do que desejamos ter agora corpos de uma matéria tão pouco corruptível quanto os diamantes, ou asas para voar como as aves (DESCARTES, 1983, p. 43, grifos nossos).
}

Mas se essa moral tivesse se tornado definitiva, o livro que a contém não nos chegaria às mãos. Isso porque a publicação do Discours de la Méthode foi motivada por outra coisa que pela resignação sóbria à necessidade: ela se justifica pela ambição "de nos tornar senhores 
e possuidores da natureza" (DESCARTES, 1983, p. 63). Escrito anos após a enumeração daquelas máximas morais provisórias, o sexto capítulo do Discours as contradiz ponto a ponto pela sua "profissão de fé tecnicista" (CANGUILHEM, 1996, p. 94) e pelo seu "entusiasmo dominador" (Ibid, p. 94). Aqui, o conhecimento é útil à vida principalmente porque eles nos informa sobre os meios pelos quais se pode conservar a saúde, combater as doenças, do corpo ou do espírito, e evitar a debilidade decorrente da velhice (DESCARTES, 1983, p. 63).

O que está em jogo nessa conversão moral, aponta Canguilhem, é o movimento pelo qual, "renunciando a fazer da necessidade virtude, Descartes se propõe e nos propõe converter em poder o conhecimento da necessidade" (1996, p. 94). Como se a desvinculação entre necessidade e realidade fosse condição de possibilidade para o aparecimento de uma reflexão sobre a técnica. É por isso que para uma filosofia que identifica natureza e Deus, Cosmos e Logos, a técnica só pode ser uma atividade supérflua, pois, conclui Canguilhem: "Toda filosofia que identifica realidade e finalidade deve estabilizar os atributos humanos num sistema hierárquico de qualidades e de essências, donde toda possibilidade de correção ou de rearranjo está excluída como devendo levar à queda de todo o edifício" (1996, p. 94).

Se Descartes pôde constituir uma reflexão sobre a técnica é porque ele rejeitou a finalidade natural do mundo e a presença de uma qualidade determinante da matéria. Como observa Canguilhem:

Na doutrina de Descartes, como naquela dos atomistas, uma matéria sem qualidades reais, um universo sem hierarquia teleológica são as razões metafísicas da fé na eficácia criadora da técnica. A enérgica negação da finalidade natural é, na filosofia de Descartes, a condição de uma teoria mecânica da natureza e de uma teoria mecanicista da arte (1996, p. 94).

É a negação cartesiana de uma concepção teleológica da realidade que Canguilhem entende se manifestar de maneira privilegiada na tese metafísica da livre criação por Deus das verdades eternas. Na carta de 15 de abril de 1630, enviada à Mersenne, Descartes escreve:

(...) eu não deixaria de tocar em minha física em muitas questões metafísicas, e particularmente nesta: Que as verdades matemáticas, às quais chamastes eternas, foram estabelecidas por Deus e Dele dependem, tanto quanto todo o resto das criaturas. É, com efeito, falar de Deus como de um Júpiter ou Saturno, e o sujeitar à Styx e aos Destinados, dizer que estas verdades são independentes Dele. (...) Foi Deus quem estabeleceu estas leis na natureza, assim como um rei estabelece as leis do seu reino (AT, I, p. 145).

O estatuto das verdades eternas é esmiuçado nas cartas de 6 (AT, I, 150) e 27 (AT, I, 152) de maio, enviadas ao mesmo destinatário. Nelas, Descartes retoma novamente a 
associação entre Deus e o legislador, para insistir na Soberania e absoluta liberdade de Deus ao instituir tais verdades. Sobre isso, Jean-Marie Beyssade observa:

É porque Ele (...) estabeleceu [a necessidade] como que por uma lei que estas verdades são necessárias, esta lei vem de uma vontade livre, que não foi necessitada a estabelecê-la pela necessidade mesma da coisa. Fundada sobre a onipotência, a liberdade de Deus rompe com toda necessidade e se manifesta pela instituição de leis cuja necessidade, para nós, não é, para ele, necessitante (1979, p. 102).

Descartes não pode aceitar que os atributos divinos se organizem em uma hierarquia, na qual o entendimento ocuparia o ápice, subordinando a ele a vontade. Se esse fosse o caso, como tentaram afirmar muitos filósofos, Deus não seria verdadeiramente livre, mas necessitado por seu entendimento.

A afirmação reiterada da liberdade divina e a consequente recusa em aceitar a idéia de um Logos impregnando todo o mundo e o determinando, conduzem Descartes a negar qualquer qualidade real à matéria. Essa se vê, portanto, reduzida à mera exterioridade quantitativa, superficialidade sem relevos ou perfeições, passível de ser transformada pelo trabalho técnico. Canguilhem resume:

Não admitir a menor anterioridade, mesmo lógica, do entendimento sobre a vontade, tomar os princípios de todo conhecimento verdadeiro na sua forma como no seu conteúdo por criaturas, isto não é somente libertar Deus de uma escravidão incompatível com sua infinidade, é também negar a finalidade no universo (1996, p. 95).

Assim, a recusa simultânea da finalidade do mundo e da qualidade da matéria são necessárias para que Descartes reconheça a imprescindibilidade da criação técnica. Daí o seu interesse por uma variada gama de problemas revelados pela artilharia, pela medicina, pela fabricação dos autômatos, pela astronomia, pela óptica etc.

Mas não podemos nos esquecer de que essa atenção dedicada às dificuldades técnicas se acompanha, ou melhor, é precedida por toda uma física e por uma metafísica. Se a técnica, para Descartes, pressupõe outros saberes, então a questão de como ele concebe as relações entre teoria e prática não é desprovida de interesse.

Não há novidade alguma, constata Canguilhem, na tese de que, para Descartes, "a consciência do possível técnico nos é dada pela consciência do necessário teórico" (Ibid, p. 97). Não é outra coisa que se deixa inferir da leitura de inumeráveis passagens nas quais o filósofo proclama a fragilidade das práticas artesanais estranhas a todo conhecimento dos objetos e dos fenômenos que elas utilizam, e reconhece a sua desconfiança pelas artes sem 
explicação (AT, I, 195), pelos inventores sem método (AT, I, 501). Sobre essa questão, nota Canguilhem, são as Regulae que trazem as declarações mais significativas. Na primeira delas, Descartes opõe à parcialidade e à diversidade das técnicas a unidade da inteligência teórica, que "se torna capaz de garantir à ação segurança e eficiência" (CANGUILHEM, 1996, p. 97). Em seguida, na quinta regra, o filósofo inscreve no conjunto dos que não observam a correta ordem e disposição dos objetos, "a maioria daqueles que estudam a Mecânica sem a Física e fabricam ao acaso novos instrumentos para produzir movimento" (AT, XI, 321).

Todavia, tal maneira de conceber as relações entre a teoria e a prática em Descartes não se sustenta diante de uma análise mais atenta das suas obras. Ao menos, é isso o que defende Canguilhem. Para ele, o filósofo francês sabe muito claramente que a passagem das ciências às técnicas não ocorre sem dificuldades, as quais nem mesmo uma inteligência perfeita, a inteligência angélica, poderia resolver. Numa carta enviada à Mersenne, Descarte, ao se referir às dificuldades advindas da fabricação de lunetas, chega mesmo a reconhecer que "existe diferença entre a teoria e a prática e que esta não pode atingir a perfeição daquela" (AT, III, 585).

Uma contradição aparece aqui: se, por um lado, Descartes afirma a homogeneidade e a convertibilidade entre a ciência e a prática, por outro, particularmente quando considera as dificuldades na fabricação de objetos técnicos, ele parece insistir na irredutibilidade da prática à ciência. É sobre este problema que Canguilhem pretende lançar alguma luz nos parágrafos finais da sua conferência.

A possibilidade da dedução analítica de toda experiência a partir de princípios intuitivamente discernidos, as chamadas naturezas simples, é o que subjaz à tese cartesiana da transformação da ciência em técnica. Porém, o desenvolvimento contínuo dessa dedução encontra seu limite nas "formas ou espécies de corpos" que são utilizados pela técnica. Se há algo nesses corpos que resiste à sua subsunção numa série dedutiva necessária, é porque a matéria com que o artesão trabalha não é a mesma que o cientista conhece: "mas se a matéria é para a ciência homogênea e anônima, a matéria que o técnico propõe oferecer a nosso uso é particular e diversa" (CANGUILHEM, 1996, p. 98).

A matéria da ciência não é outra que aquela reduzida à pura quantidade. Matéria, portanto, "homogênea e anônima", da qual somente restou a exterioridade, a superficialidade da sua extensão. O sábio, diz-nos Descartes, pode deduzir das primeiras causas "os céus, os astros, uma terra e mesmo sobre a terra a água, o ar, o fogo, os minerais" (DESCARTES apud 
Ibid, p. 98), ou seja, "os efeitos ordinários", “as coisas comuns e simples” (DESCARTES apud Ibid, p. 98).

No ateliê do artesão, sobre a bancada do mestre de ofícios, não há coisas simples, mas objetos complexos, produzidos pela composição de muitos corpos. É exatamente aí que a dedução encontra o seu obstáculo: ela se depara com uma "matéria qualificada", "particular e diversa". Se a técnica desaponta a teoria, diz-nos Canguilhem, é porque "toda a síntese técnica deve normalmente incluir, operando sobre as espécies de corpos cuja dedução não pode ser integral, a imprevisibilidade e o inesperado" (Ibid, p. 99).

A imprevisibilidade e o inesperado possibilitam a inversão das relações entre ciência e técnica ao tornarem essa última produtora de conhecimento ou, ao menos, motivo para a sua produção. Canguilhem encontra na Dioptrica um exemplo desse fato, na medida em que a óptica teórica tem como ponto de partida a invenção da luneta de aproximação, invenção devida, ela mesma, não a um conhecimento anterior, mas "à experiência e à fortuna, seguida de uma imitação servil e cega" (Ibid, p. 99). A técnica não apenas possibilita ao homem descobrir novos fenômenos pela ampliação, neste caso, das suas capacidades visuais, mas também fornece, graças às suas imperfeições, a ocasião para o desenvolvimento das pesquisas teóricas que tentam resolver essas dificuldades. Assim, pelo que nos ensina a Dióptrica, o conhecimento da natureza depende duplamente da técnica humana:

\footnotetext{
Inicialmente, no sentido em que o instrumento, aqui a luneta de aumento, serve para descobrir novos fenômenos. Em seguida e, sobretudo, (...) a ciência procede da técnica (...) nisto que o obstáculo técnico, o insucesso e o fracasso convidam o espírito a se interrogar sobre a natureza das resistências encontradas pela arte humana, à conceber o obstáculo como objeto independente dos desejos humanos e à procurar um conhecimento verdadeiro (Ibid, p. 99).
}

Se, porém, essa técnica da qual depende duplamente a ciência não depende, ela mesma, de um conhecimento anterior responsável por reger seu advento, então, pergunta Canguilhem, em que lugar é preciso procurar o seu élan, a força que a impulsiona? Não é do lado do entendimento que devemos procurar a iniciativa da técnica, mas "nas exigências do vivente" (Ibid, p. 99, grifos nossos): nas suas necessidades, apetites e vontades (Ibid, p. 100). É cedo para afirmarmos que, neste momento, ao se referir ao vivente, Canguilhem já esteja querendo designar o que mais tarde ele chamará de normatividade vital (cf. ROTH, 2010, p. 247). O mais importante aqui é o reconhecimento de uma outra ordem de exigências, de uma nova hierarquia de valores: trata-se das exigências vitais que nos impelem a agir sem que, para tanto, tenhamos sido orientados por algum conhecimento científico anterior. 
A irredutibilidade da ação ao pensamento, da técnica à ciência, a descontinuidade que se faz sentir entre a teoria e a fabricação dos utensílios, tudo isso implica, para Canguilhem, "na afirmação da originalidade de um 'poder'" (1996, p. 100). Poder humano tanto quanto divino de criar a partir de uma vontade que não se submete à legislação do intelecto.

O problema da irredutibilidade da criação ocupa o centro da argumentação de uma comunicação apresentada em 26 de fevereiro de 1938, no encontro da Société Toulousaine de Philosophie, posteriormente publicada sob o título: Activité technique et création.

A invenção técnica constitui, segundo Canguilhem, um problema maior para a Filosofia, na medida em que esse fenômeno coloca em questão a perspectiva teórica hegemônica pela qual se buscava fornecer uma explicação capaz de unificar a experiência humana. O que é problematizado aqui é a chamada filosofia cientista - compartilhada tanto por materialistas quanto por positivistas-, para a qual todas as funções do espírito humano poderiam ser reduzidas à função de determinação teórica, isto é, ao conhecimento.

Comte, Claude Bernard e Durkheim poderiam ser facilmente enquadrados nessa filosofia, na medida em que, como vimos, defendiam a dependência da técnica humana a um conhecimento prévio que lhe fornecesse suas regras de ação. Isso implicava admitir, observava Canguilhem, que as possibilidades da intervenção técnica se limitavam aos parâmetros determinados pela normalidade de fato, aos quais a terapêutica médica ou social deveriam reconduzir os fenômenos desviantes. Essa já era a interpretação canguilhemeana da filosofia cientista neste artigo de 1938, em que o filósofo afirma que cientismo identifica o possível ao real ou ao fato, recusando que:

Toda criação tem como preocupação primeira o que lhe resiste. Aquele que não admite outro valor que o real, sacrifica alegremente todos os possíveis. Aquele que tende passionalmente para um possível não pode ignorar o real, já que a realidade é o que ele deve negar de início a fim de realizar o seu possível. A criação, passagem do nada ao ser, é a substituição do ser do possível ao nada do real (CANGUILHEM, 1938, p. 82).

A oposição entre o real ou o fato e o possível parece colocar a filosofia canguilhemeana da técnica em continuidade com a tradição aristotélico-escolástica, como se, para Canguilhem, fosse também o caso de afirmar um certo tipo de finalismo de acordo com o qual a causa final, entendida como perfeição e bem último da existência, desse sentido à causa eficiente e à causa formal. Isso seria verdade, porém, se o filósofo francês fizesse desse possível um fato mais real do que aquilo que se apresenta para a ciência como realidade, isto é, se o possível fosse identificado ao ser criado por um ato soberano da vontade de Deus. 
Porém, em Canguilhem, temos algo completamente diferente, e aqui se concentra o núcleo da sua concepção de normatividade vital. Para compreendermos esse ponto, é preciso sublinhar, antes, que à época desta conferência, o filósofo ainda se encontrava bastante próximo dos problemas da chamada "Escola Francesa da Percepção ${ }^{36, ", ~ e m ~ p a r t i c u l a r ~ d a q u e l e ~ c o n c e r n e n t e ~}$ à primazia do entendimento sobre a ação. Com efeito, reduzindo toda ação a uma atividade do espírito, isto é, do entendimento, a "Escola da atividade" advogava uma espécie de intelectualismo, que fazia ecoar a máxima comteana: "ciência, então previsão; previsão, então ação". Tratava-se, para esses teóricos, de afirmar que todas as funções do entendimento se reduzem à forma do julgamento científico, ao qual as demais atividades do espírito, dentre elas a própria técnica, estão subordinadas. Como resume Roth,

o conhecimento do que as coisas valem depende para Alain do conhecimento do que elas são. Dito de outra maneira, todos os problemas se reconduzem segundo ele a um problema de julgamento de conhecimento. (...) é apenas se elevando da imaginação para o entendimento, da ficção para o conhecimento, que nós conheceremos as coisas tais quais elas são, mas também, por isso mesmo, seu valor verdadeiro. A experiência apenas tira o seu sentido no e pelo prisma da verdade (2010, p. 273).

Dissociar o espírito da sua adesão especulativa ao fato é, como insistimos desde o início, a tarefa maior de Canguilhem ao abordar a questão da atividade técnica e da criação. Essa dissociação começa a se estabelecer no momento em que o filósofo situa a técnica em relação à percepção. Ambas as atividades se dão numa dimensão pré-crítica, irrefletida, diferenciando-se uma da outra pelo objetivo que visam: a percepção visa o conhecimento, operando para tanto distinções quantitativas e análises grosseiras, que estão vinculadas às “impulsões psicofisiológicas de um organismo assujeitado por sua estrutura hereditária a um ritmo coercitivo de necessidades inicialmente específicas" (CANGUILHEM, 1938, p. 83); a

\footnotetext{
${ }^{36}$ Essa expressão foi utilizada por Roth, que, por sua vez, a empresta de Gérard Granel, para se referir à escola de pensamento que vai Lagneau à M. Alexandre, passando por Alain e Lachelier. Em linhas gerais, o que une esses teóricos, completa Roth, é a tese de que "loin d'être une faculté essentiellement passive, une analyse dite « réflexive » révèle au contraire que la perception est avant tout une activité par laquelle l'esprit impose son ordre à un divers d'impressions indifférent. Selon nous, cette Ecole réflexive est le fruit de la réception de Kant dans la France de la seconde moitié du 19ème siècle, réception qui s'articule autour des notions ' d'unité originairement synthétique de l'aperception ' et de ' synthèse ' notamment" (2010, p. 78). Ainda de acordo com Roth, Canguilhem é um herdeiro direto dessa escola de pensamento francesa: "notamment dans sa manière de mêler inextricablement arguments épistémologiques et considérations morales. Que l'esprit soit une activité de mise en ordre et de valorisation,Canguilhem s'en souviendra lorsqu'il étendra, non sans aménagements, les principes de cette philosophie de l'esprit au plan vital : l'Essai ne définit-il pas en effet explicitement la vie comme 'une activité d'information et d'assimilation de la matière' ?" (Ibidem, p. 78-79). Contudo, se é explícita a estreita relação entre o jovem Canguilhem e a "Escola francesa da percepção", cujos grandes representantes foram, direta ou indiretamente, responsáveis pela formação intelectual do nosso filósofo, consideramos, contudo, que a ruptura com a mesma foi mais radical do que Roth está disposto a admitir na sua tese.
} 
técnica visa a criação, "produções qualificadas, então concretas ou sintéticas" (ibidem, p. 83). Por que a técnica é convocada? Justamente porque o fato percebido não é suficiente para realizar as expectativas vitais do homem. Assim, a técnica revela, mais do que a percepção, o impulso de ultrapassamento do dado que é próprio do espírito, pois, como define Canguilhem, “o espírito é, na nossa experiência, a possibilidade de não poder ser satisfeito por qualquer realidade finita que seja, e de alterar essa realidade, relacionando-se com alguma potência de julgamento e, então, de correção" (ibidem, p. 83).

Ou seja, a atividade do espírito não se restringe à organização dos dados perceptivos visando o conhecimento do fato; ela, para Canguilhem, manifesta-se como ato criador, que, ao invés de se limitar a reinstaurar as normas definidas pelo conhecimento científico do fato, põe essas normas como aquilo que dele procede. Enquanto que, na tradição escolástica, o possível é a realidade última ou Deus enquanto causa final, capaz de orientar a causa eficiente, isto é, a atividade criadora, no caso de Canguilhem, o possível é criação de um possível que excede a realidade, que ultrapassa o fato. A profanação canguilhemeana se faz clara nesta passagem:

\footnotetext{
Compreende-se então que a potência de criação depende do ato, no sentido em que a potência é posterior ao ato. $O$ criador vale mais que a criatura (sendo em potência outras criaturas), mas após a criação e não antes. Segundo uma palavra notável: "a gênese cria Deus" (Ibidem, p. 85).
}

Estas teses implicam na necessidade de se recompreender as relações entre as ciências e as técnicas. Contra o cientismo, não se trata de adotar uma espécie de pragmatismo que faria da ciência um prolongamento da técnica, mas, mais propriamente de afirmar que não há continuidade possível entre ciência e técnica em qualquer um dos sentidos: se, por um lado, "a lucidez teórica nunca pode ser uma razão suficiente para passar ao ato" (ibidem, p. 84), por outro, o ato não pode conduzir a um saber sobre ele. Assim, a relação entre ciência e técnica "não é de modo algum o prolongamento de um élan, mas ao contrário sua interrupção. $O$ impulso do pensamento científico tem por condição o fracasso da técnica" (ibidem, p. 84).

No ano anterior, em Descartes et la technique, ao comentar a descoberta das leis da dióptrica a partir de um problema suscitado pela necessidade de definir o tamanho das lentes, Canguilhem já opunha a imprevisibilidade da técnica à rigorosa necessidade com que o conhecimento científico opera. Isso permitia a ele, na ocasião, enraizar a criação técnica no vivente, que não se submete passivamente a uma realidade toda acabada, mas a transforma dissolvendo as normatividades fixas do meio. Esse argumento será desenvolvido em L'activité technique et création. Nessa conferência, Canguilhem recusará admitir a 
demarcação entre as máquinas primitivas ingênuas, encontradas na origem dos instrumentos técnicos mais complexos, e os órgãos montados pela vida:

\begin{abstract}
Uma máquina, no fundo, é apenas o produto de um esforço universal de organização que a consciência humana alimenta, num momento dado, com os resultados do seu esforço de conhecimento. (...) Notar-se-á facilmente como a tese proposta se aproxima do bergsonismo (geralmente tão mal compreendido) e como dele se desvia (Ibidem, p. 86).
\end{abstract}

Sem se tornar um bergsoniano convicto (CANGUILHEM, 1947, p. 332) ${ }^{37}$, Canguilhem sempre atribuiu à Bergson o mérito de ter sido, "um dos raros filósofos franceses, senão o único, que considerou a invenção mecânica como uma função biológica, um aspecto da organização da matéria pela vida" (1975, p. 125, n. 58). Na vasta produção do filósofo francês, L'évolution créatrice é a obra que, para Canguilhem, estabelece as bases de uma “organologia geral" (Ibidem, p. 125, n. 58; 1947, p. 332), reinscrevendo a história do mecanismo na história da vida.

Com efeito, na obra acima mencionada, Bergson nota que, nos animais, há uma estreita imbricação entre instinto e técnica, donde essa definição: “o instinto acabado é uma faculdade de utilizar e mesmo de construir instrumentos organizados" (BERGSON, 2008, p. 141). A peculiaridade é que os mecanismos dos quais se serve o instinto fazem parte do próprio corpo do organismo. Nesse sentido, todo instinto tem à sua mão um instrumento apropriado para a satisfação das necessidades imediatas do ser vivo, dos quais os órgãos constituem o exemplo mais evidente. Disso resulta a especialização do instinto, "não sendo ele senão a utilização, para um objeto determinado, de um instrumento determinado" (Ibidem, p. 141).

A inteligência do homem, na medida em que para Bergson ela é originalmente uma faculdade de $a c ̧ a ̃ o$, e não de especulação, difere do instinto apenas porque os instrumentos que produz são objetos artificiais, utensílios fabricadores de utensílios, que não estão vinculados a um uso determinado, prestando-se a um número ilimitado de poderes. Mais do que isso: o instrumento artificial criado pela inteligência reverte em transformações na própria natureza do ser que o fabricou,

pois, chamando a exercer uma nova função, ele lhe confere, por assim dizer, uma organização mais rica, sendo um órgão artificial que prolonga um organismo natural.

\footnotetext{
${ }^{37}$ As relações entre Canguilhem e a filosofia de Bergson são complexas e variam ao longo de toda a experiência intelectual canguilhemeana. Para uma análise detalhada dos diversos momentos constitutivo da relação entre os dois filósofos, ver BIANCO, 2007.
} 
Pra cada necessidade que satisfaz, ele cria uma necessidade nova, e assim, ao invés de fechar, como o instinto, o círculo da ação em que o animal vai se mover automaticamente, ele abre a essa atividade um campo indefinido em que ele a impulsiona mais e mais longe, e a faz cada vez mais livre (ibidem, p. 142).

Nessas considerações, importa para Canguilhem a concepção bergsoniana de que os órgãos do corpo já são, em si mesmos, instrumentos naturais criados pelo e para o instinto que vai dele se servir. Eis o que permite ao autor de La connaissance de la vie afirmar que, com Bergson, a filosofia da técnica se enraizou numa filosofia da vida. Em relação a esses instrumentos naturais, os órgãos artificiais, ou seja, os objetos técnicos, são como que sua a extensão, o que explicitamente se defende em Les deux sources de la morale et de la religion: "Se nossos órgãos são instrumentos naturais, nossos instrumentos são por isso mesmo órgãos artificiais. O utensílio do trabalhador continua seu braço; o instrumental da humanidade é então um prolongamento do seu corpo" (1997, p. 329-330).

Tomando a técnica humana como prolongamento do impulso propriamente vital de organização da matéria, a filosofia bergsoniana ultrapassa assim a clivagem aristotélica entre um tipo de atividade (ergon) comum a todo ser vivo (zoé) e outro tipo, específico do homem, e que é a atividade da alma segundo o logos. Contudo, ao colocar as coisas dessa maneira, o Estagirita, e, com ele, toda a tradição metafísica ocidental, eram vítimas de uma espécie de ilusão retroativa sobre a natureza da inteligência e suas relações com a vida. Com efeito, como a inteligência se converteu numa atividade especulativa, os filósofos projetam essa forma atual na sua origem, esquecendo-se de que ela é uma faculdade originalmente prática vinculada à satisfação das exigências biológicas dos seres vivos. Como comenta Lebrun sobre Bergson, os filósofos:

a consideravam [a inteligência] no seu aspecto terminal, e como não pensavam em fazer (ou não estavam em condições de fazer) a sua genealogia, eles lhe atribuíam um falso destino: porque ela é efetivamente a única faculdade a "se inquietar com a teoria", eles a acreditaram teórica, e feita, por conseguinte, para resolver problemas especulativos (1993, p. 216).

Bergson defende uma ideia radicalmente diferente. Se, para ele, a inteligência é uma faculdade essencialmente voltada para a ação e para a fabricação, se também, como vimos, a invenção de objetos técnicos continua no homem o impulso de organização da vida, então é bem necessário admitir que a inteligência não existe destacada dessa vida como um princípio extra-natural ou transcendente, o intelecto ativo aristotélico. O logos, ao contrário, não se separa do zoé, do ser em vida: "mas é justamente dever da especulação verdadeira dissipar 
essa ilusão, e pensar o 'zoon logikon' sem recair na superstição de um 'logos' supra vital" (Ibidem, p.216).

Assim, sobre Bergson, Canguilhem é capaz de fundamentar a tese de que a criação técnica é anterior e, portanto, irredutível ao conhecimento teórico que a suplementa e aperfeiçoa. A técnica, como desdobramento da capacidade criadora da vida, funda o logos. Nesse sentido, resume mais uma vez Lebrun à propósito de L'évolution créatrice, o Homo faber é a verdade do Homo sapiens.

\section{Animais e máquinas}

A transformação das relações entre técnica e ciência, de forma a inverter a posição de prioridade entre elas, implica dissociar a invenção técnica da sua subordinação ao intelecto humano para inscrevê-la no organismo. Com isso, em uma das conferências dadas em 19461947, no Colège philosophique, posteriormente publicada em La connaissance de la vie sob o título Machine et organisme, Canguilhem pode então tratar, a partir de uma nova perspectiva, o problema biológico do organismo-máquina, normalmente abordado num único sentido: aquele que parte da estrutura e do funcionamento da máquina já construída para explicar a estrutura e o funcionamento do organismo (CANGUILHEM, 1975, p. 101). Porém, ao conceber a invenção técnica como um modo de comportamento do vivente, o filósofo é capaz de procurar "compreender a construção mesma da máquina a partir da estrutura e do funcionamento do organismo" (Ibidem, p. 101).

Para que a máquina se tornasse o modelo de inteligibilidade das funções biológicas foi necessário o advento dos autômatos, "cujo nome significa, ao mesmo tempo, o caráter miraculoso e a aparência de autossuficiência de um mecanismo transformando uma energia que não é, imediatamente ao menos, o efeito do esforço muscular humano ou animal" (Ibidem, p. 104). Com efeito, as máquinas cinemáticas não eram capazes de fornecer uma explicação suficiente do orgânico na medida em que elas dependem, para o seu próprio funcionamento, de uma fonte externa de energia; já os autômatos realizavam um tipo de movimento cuja energia era proveniente de motores internos à própria máquina. Assim, distanciando o vivente, como fonte de energia, da máquina que ele coloca em movimento, a explicação do organismo pela máquina pôde aparecer: "é a separação entre o momento da restituição de energia e aquele do armazenamento da energia restituída pelo mecanismo que 
permite o esquecimento da relação de dependência entre os efeitos do mecanismo e a ação do vivente" (Ibidem, p, 106).

Não é por acaso, portanto, que relógios, moinhos, máquinas de suspensão, fontes artificiais, e outros tipos de autômatos, constituem, para Descartes, análogos do corpo humano, criado por Deus. Eis o que se observa claramente nesta passagem do Traité de l'Homme, citada por Canguilhem:

Suponho que o corpo não seja outra coisa senão uma estátua ou máquina de terra, que Deus forma intencionalmente para torná-la o mais possível semelhante a nós. De modo que ele não apenas lhe dá externamente a cor e a figura de todos os nossos membros, como também coloca dentro dela todas as peças que são necessárias para fazer que ela ande, coma, respire e, em enfim, imite todas as nossas funções que possam ser imaginadas como procedentes da matéria e que só dependem da disposição dos órgãos.

Nós vemos relógios, fontes artificiais, moinhos e outras máquinas semelhantes que, sendo feitas pelos homens, não deixam de ter a força de se mover por si mesmas de diversas maneiras. Parece-me que eu não conseguiria imaginar tantos tipos de movimentos nela, que suponho ser feita pelas mãos de Deus, nem lhe atribuir tanto artifício, que vós não possais pensar que nessa máquina possa haver ainda mais (DESCARTES, 2009, p. 251).

Nessa citação, Canguilhem destaca dois postulados sem os quais a teoria cartesiana do animal-máquina não teria sentido: "dito de outra maneira, é necessário compreender o animalmáquina, percebê-lo como precedido, no sentido lógico e cronológico, ao mesmo tempo por Deus, como causa eficiente, e por um vivente preexistente a imitar, como causa formal e final” (CANGUILHEM, 1975, p. 112). De fato, a norma que Deus realiza, como Artifex Maximus, na criação do animal-máquina é um vivente humano prévio. Essa referência necessária a uma espécie de protótipo orgânico original faz reaparecer no interior da teoria do animal-máquina justamente aquilo que ela parecia exorcizar: a teleologia. Afirma Canguilhem:

$\mathrm{Na}$ verdade, não se pode, parece, opor mecanismo e finalidade, não se pode opor mecanismo e antropomorfismo, pois se o funcionamento de uma máquina se explica por relações de pura causalidade, a construção de uma máquina não se compreende nem sem a finalidade, nem sem o homem. Uma máquina é feita pelo homem e para homem, em vista de alguns fins a obter, sob forma de efeitos a produzir (Ibidem, p. 114).

Não deixa de causar estranheza essa afirmação canguilhemeana que associa mecanicismo e antropomorfismo, afinal esse último parece ser apanágio daquelas teorias biológicas que fazem apelo à irredutibilidade do vivente em relação ao mundo inorgânico, irredutibilidade que seria justificada pela atribuição de qualidades humanas aos seres vivos 
como um todo. Porém, o que é realmente espantoso na análise que Canguilhem faz do animalmáquina é justamente a descoberta, no cerne do mecanicismo biológico, de uma concepção de finalidade antropomórfica que põe um artífice como causa e fim da criação. De fato, se o mecanicismo consegue explicar o funcionamento da máquina a partir de leis puramente físicas, ele não consegue, todavia, dar conta da criação e da manutenção das máquinas a partir de peças isoladas sem fazer intervir um Deus ou um criador que fixa a direção do seu movimento de uma vez por todas, garantindo a reunião interna das partes: “(...) a direção do movimento é incluída pelo construtor no dispositivo mecânico de execução" (Ibidem, p. 115).

A determinação do movimento das máquinas faz delas estruturas cuja finalidade é rígida e unívoca, univalente. Cada peça de uma máquina, com efeito, executa somente uma única função, que lhe fora determinada previamente, na qual não pode ser substituída senão por uma outra peça de características métricas e qualitativas idênticas. O mesmo não se observa nos seres vivos, acerca do qual diversos experimentos listados por Canguilhem revelam a polivalência dos órgãos e das funções: um único órgão realizando várias funções e um função sendo executada por vários órgãos. Nesse sentido, é bem preciso admitir que, no que diz respeito aos organismos,

\footnotetext{
há menos finalidade e mais potencialidades. A máquina, produto de um cálculo, verifica as normas do cálculo, normas racionais de identidade, de constância e de previsão, enquanto que o organismo vivente age segundo o empirismo. A vida é experiência, isto é, improvisação, utilização em todos os sentidos. Donde esse fato, ao mesmo tempo massivo e muito frequentemente desconhecido, de que a vida tolera monstruosidades. (...) Enquanto que os monstros são ainda viventes, não há distinção do normal e do patológico em física e em mecânica. Há uma distinção entre o normal e o patológico no interior dos seres vivos (Ibidem, p. 118).
}

Sem flexibilidade de normas, incapazes de colocarem para si mesmos outros fins que não os que foram definitivamente inscritos neles pelo seu artífice, os mecanismos são sempre normais. É certo que eles podem quebrar, deixar de funcionar etc, mas isso não significa para eles a invenção de um novo modo de funcionamento senão que a peça danificada deve ser reposta por aquele que os criou. Nos seres vivos, como revelam os estudos de embriologia experimental em que se apoia Canguilhem, desvios no processo de desenvolvimento embriológico podem conduzir a novas formas de organização. Se, por exemplo, comprime-se um ovo de ouriço em determinado estado até que a posição relativa das células se modifique nos dois polos, tem-se, segundo o experimento de Driesch (Ibidem, p. 119), a maturação normal do ovo e o consequente nascimento do filhote de ouriço. Assim, conclui Canguilhem: 
Parece-nos então que se ilude pensando expulsar a finalidade do organismo pela assimilação desse último a uma composição de automatismos tão complexos quanto se queira. Tanto a construção da máquina não será uma função da própria máquina, tanto a totalidade do organismo não será equivalente à soma das partes que uma análise aí descobre uma vez que ele é dado, poderá parecer legitimo tomar a anterioridade da organização biológica como uma das condições necessárias da existência e do sentido das construções mecânicas (Ibidem, p. 120).

Se é possível identificar a gênese da atividade técnica no ato propriamente vital da criação, então é forçoso reconhecer que os fenômenos vitais estão longe de serem redutíveis a um sistema completo de determinação. Da mesma maneira que a invenção técnica não depende totalmente do conhecimento teórico, mas estabelece com esse uma relação ao mesmo tempo de ruptura e da produção, a vida, enquanto potência de criação, não se esgota nas formas normais de organização vivente.

Coloca-se, assim, um problema fundamental: se a estrutura da máquina não é mais capaz de explicar a estrutura biológica dos organismos, se, ao contrário, é essa que torna inteligível aquela, então como responder ao problema principal da biologia: “(...) a questão de saber de onde vem a ordem e o sentido - problema tão característico do comportamento orgânico - neste caos que é a soma enorme de fatos separados e contraditórios" (GOLDSTEIN, 1949, p. 141).

\section{O conhecimento vital da vida}

As ciências físico-químicas não podem oferecer qualquer resposta a essa questão na medida em que elas assumem a perspectiva teórica criticada por Canguilhem, adotando as máquinas como modelo de inteligibilidade dos organismos. Assim como aquelas, esses também seriam explicáveis a partir da análise das totalidades em partes exteriores umas às outras, vinculadas por relações de causa e efeito. Porém, a reflexão canguilhemeana sobre os mecanismos nos revelou a precedência histórica e lógica do orgânico sobre o maquínico. Por isso, ao assimilar os métodos e protocolos de racionalidade das ciências físico-químicas, as ciências biológicas acabam por dissolver a originalidade do seu objeto num composto reações isoladas. Com efeito, explica o filósofo:

A vida é formação de formas, o conhecimento é análise das matérias informes. É normal que uma análise nunca possa dar conta de uma formação e que se perde de vista a originalidade das formas quando aí se vê apenas resultados dos quais se procura determinar os componentes. Sendo totalidades cujo sentido reside na sua tendência a se realizar como tais no curso de sua confrontação ao meio, as formas viventes podem ser apreendidas numa visão, nunca numa divisão. Pois dividir é, no 
limite, e segundo a etimologia, fazer o vazio, e uma forma, existindo somente como um todo, não pode ser esvaziada de nada (1975, p. 11).

Era esse tipo de análise que Claude Bernard expressamente indicava no seu método experimental. Como vimos no capítulo anterior, para que o fisiologista fosse capaz de eliminar definitivamente da noção de patologia qualquer vestígio de uma qualidade nova, fazia-se necessário dividir a doença numa série de mecanismos e num feixe de relações isoladas, cuja explicação se dá unicamente pelo recurso às leis físico-químicas.

Para se tornar um conhecimento verdadeiramente biológico, as ciências da vida precisam recuperar o caráter indivisível, holístico, dos fenômenos com os quais se ocupam, reinserindo-os na totalidade orgânica que lhes dá sentido. Quanto a isso, Canguilhem é claro:

\begin{abstract}
O estudo biológico da alimentação não consiste somente em estabelecer uma taxa, mas em procurar no próprio organismo o sentido da escolha que, no estado livre, ele opera no seu meio para fazer de determinadas espécies ou essências o seu alimento, com a exclusão de outras que poderiam, com rigor teórico, proporcionar-lhe aportes energéticos equivalentes para a sua manutenção e crescimento. $\mathrm{O}$ estudo biológico do movimento apenas começa com a consideração da orientação do movimento, pois ela apenas distingue o movimento vital do movimento físico, a tendência, da inércia. $(1975$, p. 12)
\end{abstract}

O que se aplica ao estudo da alimentação e do movimento vale também para outros fenômenos biológicos, como, por exemplo, para aqueles que são objetos da fisiopatologia: seu sentido vital não se deixa determinar objetivamente por métodos científicos tomados de empréstimo das ciências físico-químicas. Afinal, o que distingue a saúde da doença? Como determinar o limite em que uma variação individual, uma anomalia, advém anormalidade? De que maneira se pode estabelecer uma hierarquia entre normas vitais superiores e inferiores?

Não se pode negar que as ciências naturais lograram resultados consideráveis no diagnóstico, tratamento e prognóstico de diversos transtornos biológicos. Mas não é aí que se encontra o problema para Canguilhem. A questão é mais a de revelar que, sob os sucessos das ciências analíticas, antes mesmo dele, há uma dimensão como que recalcada pela epistemologia, dimensão irracional e plástica que é a do sentido propriamente vital dos fenômenos. Com efeito, no Essai, observa Canguilhem:

Procurando determinar as constantes e as invariantes que definem realmente os fenômenos da vida, a fisiologia faz autenticamente obra de ciência. Mas procurando qual é o sentido vital dessas constantes, qualificando umas de normais e outras de patológicas, o fisiologista faz mais - e não menos - que obra de ciência estrita. Ele não considera somente a vida como uma realidade idêntica a si, mas como um movimento polarizado. Sem o saber, o fisiologista não considera mais a vida com um olho indiferente, com o olho do físico que estuda a matéria, ele considera a vida 
na qualidade de vivente que a vida também atravessa num certo sentido (2007, p. 149-150).

Um cientista que se engaja na pesquisa de certo tipo de alteração das constantes fisiológicas responsáveis por um conjunto de sintomas mórbidos, sabe de antemão do valor negativo, patológico, das transformações que o interessam. A pretensa objetividade das ciências da vida se fundamenta assim na polaridade vital que é a única a poder distinguir, no plano subjetivo antes que no objetivo, a saúde da doença, o normal do patológico:

É a própria vida, pela diferença que ela estabelece entre seus comportamentos propulsivos e seus comportamentos repulsivos, que introduz na consciência humana as categorias de saúde e de doença. Essas categorias são biologicamente técnicas e subjetivas e não biologicamente científicas e objetivas. Os viventes preferem a saúde à doença (Ibidem, p. 150).

Tanto Comte quanto Claude Bernard afirmavam, como vimos, a prioridade do conhecimento do normal em relação à determinação do patológico. Contudo, essa afirmação apenas era possível no interior de uma concepção de normalidade compreendida como um fato, como um dado apreensível segundo procedimentos gerais de medição. Nesse caso, uma vez estabelecido o normal, chegava-se ao patológico a partir da aferição das variações quantitativas observadas naquele. Porém, ao colocar em evidência o caráter valorativo do normal, Canguilhem é levado a pensar que

\begin{abstract}
é a experiência de um obstáculo, vivido inicialmente pelo homem concreto, que suscitou a patologia, sob seus dois aspectos, de semiologia clínica e de interpretação fisiológica dos sintomas. Se não houvesse obstáculos patológicos, não haveria também fisiologia, pois não haveria problemas fisiológicos a resolver. Resumindo as hipóteses que nós propomos a respeito das ideias de Leriche, nós podemos dizer que em matéria biológica, é o pathos que condiciona o logos porque ele o chama. É o anormal que suscita o interesse teórico pelo normal. As normas não são reconhecidas como tais senão nas infrações. As funções não são reveladas senão por seus desvios. A vida não se eleva à consciência e à ciência dela mesma senão pela inadaptação, pelo fracasso, pela dor (Ibidem, p. 139).
\end{abstract}

De fato, os estudos de Leriche sobre o fenômeno da dor mostraram a Canguilhem o seu sentido hedônico, normativo. Para o cirurgião francês, a dor comporta algo além dos seus elementos puramente fisiológicos: ela não é o mero efeito de certo tipo de influxos nervosos, mas o resultado da cooperação entre esses e o modo como o indivíduo ativamente reage aos estímulos que a provocam ${ }^{38}$. Canguilhem irá ainda mais longe, concebendo a dor como a

\footnotetext{
${ }^{38}$ Vale lembrar que Canguilhem não pode reconhecer a ocorrência de estados biológicos originados apenas da submissão do indivíduo àquilo que o afeta. Isso em razão de que a vida, segundo o filósofo (2007), nunca é
} 
expressão de um valor vital que não seria negado mesmo que se recuse sua localização anatomofisiológica $^{39}$ :

Pode-se admitir que a dor seja um sentido vital, sem admitir que tenha um órgão específico nem que tenha um valor enciclopédico de informação na ordem topográfica ou funcional. O fisiologista bem pode denunciar as ilusões da dor, como o físico o faz em relação às da óptica, isto significa que um sentido não é um conhecimento e que seu valor normal não é um valor teórico, o que não acarreta que o sentido não tenha normalmente o seu valor (Ibidem, p. 57).

Daí porque Canguilhem não deixará de insistir, com Leriche, que a dor é um fenômeno que convoca a totalidade do organismo e que somente tem sentido no nível da individualidade humana concreta (Ibidem, p. 56). Afligido pela dor, o vivente procura alternativas para minimizá-la, criando comportamentos novos a fim de manter-se vivo no seu meio de existência. Tal é o caso da osteoartrite tuberculosa do joelho (Ibidem, p. 120), doença em que o enfermo imobiliza sua articulação em uma posição intermediária entre a extensão e a flexão (posição de Bonnet), para aliviar a pressão exercida sobre as superfícies articulares. Nesse sentido, o filósofo observa que:

(...) o homem faz a sua dor - como ele faz uma doença ou como ele faz seu luto bem mais que ele a recebe ou a sofre. Inversamente, ter a dor como uma impressão recolhida num ponto do corpo e transmitida ao cérebro é supô-la totalmente constituída como tal, fora de toda relação à atividade do sujeito que a experimenta (Ibidem, p. 56-57).

O esforço vital de instauração de um novo normal conduz à terapêutica, técnica propriamente humana de reconfiguração dos modos de ser do vivente cujas normas não são mais capazes de realizar suas expectativas de sobrevivência num dado meio. No que diz respeito ao saber médico, é novamente o esforço vital que está na sua origem. O logos é posterior ao pathos e à técnica. Nada há com que se espantar, portanto, nesta afirmação que aparece na introdução do Essai: "A medicina nos aparecia, e nos aparece ainda, como uma técnica ou uma arte no cruzamento de muitas ciências, mais do que como uma ciência propriamente dita" (Ibidem, p. 7).

indiferente às condições do seu meio: ela é debate (p. 131) e posição de valor (p. 77). Nesse sentido, não há patologia que resulte puramente, como a etimologia da palavra poderia sugerir, da passividade do vivente. A doença é ainda uma norma de vida, na medida em que exprime uma relação com a normatividade vital (p. 154), mas é uma norma qualitativamente diferente daquela da saúde (p. 119-120).

${ }^{39}$ Laurence Croix distingue a dor física da dor orgânica. A primeira é sentida fisicamente, mas não possui um suporte fisiológico e nem uma origem orgânica determinável. Tal é o caso da dor em membros fantasmas, cf., principalmente, o primeiro capítulo de CROIX, Laurence. La douleur em soi, de l'organique à l'inconscient. Toulouse: Érès, 2002. 
Porém, para apreender nesses fenômenos o que os define como vitais, diferenciandoos daqueles que são passíveis de uma explicação por redução analítica, "o pensamento do vivente deve ter do vivente a ideia do vivente" (1975, p. 13, grifos nossos). Essa noção de ideia do vivente, o filósofo a toma de empréstimo das reflexões de Goldstein sobre a essência do conhecimento biológico.

Segundo Goldstein, a ideia não é outra coisa que uma imagem da totalidade que permite ao cientista distinguir, dentre os fatos de que ele dispõe, e que foram obtidos analiticamente, aqueles pertencentes a essa totalidade e os que são contingentes. Quem bem compreendeu o papel desempenhado pela ideia no conhecimento biológico foi um leitor atento de Goldstein, Merleau-Ponty ${ }^{40}$ :

\begin{abstract}
Uma análise molecular total dissolveria a estrutura das funções e do organismo na massa indivisa das reações físicas e químicas banais. A vida não é, pois, a soma dessas reações. Para fazer reaparecer, a partir delas, um organismo vivo, é preciso traçar, nelas, linhas de clivagem, escolher pontos de vista nos quais certos conjuntos recebem um significado comum e aparecem, por exemplo, como fenômenos de 'assimilação', como os componentes de uma 'função de reprodução', donde certas séries de acontecimentos, até então imersos num devir contínuo, se distinguem como fases - o crescimento, a idade adulta - do desenvolvimento orgânico. Devemos separar mentalmente certos fenômenos parciais do seu contexto real e subsumi-los a uma ideia que não está contida, mas expressa neles (2002, p. 164-165, grifos nossos).
\end{abstract}

Isso quer dizer que, para Goldstein, a ideia não possui qualquer estatuto ontológico; ela é um ente de razão, como reconhece o próprio neurologista alemão: "Nós não procuramos um fundamento [Grund] de realidade que funda o ser, mas nós procuramos uma ideia, um fundamento de conhecimento [Erkenntinisgrund] permitindo-nos verificar todas as particularidades" (1983, p. 313). Tudo se passa, portanto, como se estivéssemos diante do projeto kantiano $^{41}$ de justificação da possibilidade do conhecimento empírico dos organismos vivos a partir do recurso a um princípio subjetivo de finalidade ${ }^{42}$. Porém, ainda que o seu

\footnotetext{
${ }^{40}$ A referência à Le structure du comportement, de Merleau-Ponty, justifica-se no contexto desta pesquisa sobre Canguilhem porque no prefácio à segunda edição do seu Essai, o filósofo se refere explicitamente às contribuições que sua tese teria obtido da leitura de Le structure, se as condições de difusão dos livros não fossem tão precárias nos anos 1940 (CANGUILHEM, 2007, p. 3).

${ }^{41}$ Nesse conceito de ideia como fundamento de conhecimento [Erkenntinisgrund] não é possível deixar de escutar os ecos da terceira crítica de Kant, filósofo particularmente importante para reflexão de Goldstein sobre o organismo, como ele próprio revela: "En dernier lieu, j'aimerais mentionner l'influence des idées philosophiques, particulièrement de celles de Kant, Ernst Cassirer et Edmund Husserl. Mon introduction du concept 'd'existence' dans l'interpretation du comportment humain - en grand partie développée a partir d'observations - renvoie finalement à la théorie transcendantale de la connaissance de Kant" (1971, p. 11).

${ }^{42}$ Sobre a finalidade como um princípio subjetivo, nós nos apoiamos na excelente tese de Rachel ZUCKERT, Kant on beauty and biology, particularmente na introdução e primeira parte, cuja referência completa se encontra na bibliografia.
} 
emprego seja necessário para o conhecimento dos seres biológicos, esse princípio “é puramente regulativo, o qual é ele próprio 'inexplicável', e não explica verdadeiramente o funcionamento orgânico" (ZUCKERT, 2007, p. 2). No caso de Goldstein, a ideia, enquanto um construto da mente do biólogo, é também um princípio regulativo que nada diz sobre a realidade dos fenômenos orgânicos que visa conhecer. Não soa, portanto, surpreendente a conclusão a que Merleau-Ponty chega à propósito de Goldstein: “o organismo do qual a análise biológica se ocupa é uma unidade ideal" (2002, p. 165).

A ideia, segundo Goldstein, resulta de um ato criador que é "essencialmente semelhante à atividade pela qual o organismo compõe com o mundo ambiente de maneira a poder se autorrelizar, isto é, existir. O conhecimento biológico reproduz de uma forma consciente os procedimentos do organismo vivente" (GOLDSTEIN, 1949, p. 143). Em outras palavras, a atividade do biólogo espelha, no âmbito cognitivo, o esforço pelo qual o vivente se confronta aos obstáculos do meio pelo aprendizado de uma nova função ou de um novo modo de organização. Goldstein vai ilustrar a sua concepção de ato criador com um exemplo banal: a aprendizagem do andar de bicicleta. Para isso, fazemos movimentos desordenados, sem qualquer relação com aqueles que são essenciais para se andar de bicicleta. Os primeiros não nos conduzem, mesmo que submetidos a um cuidadoso aprimoramento, aos segundos. Esses, afirma Goldstein (1983, p. 313), “aparecem subitamente no momento em que se efetua a adequação entre a atividade do organismo e as condições do seu meio". Não há, assim, separação entre o ato de pedalar uma bicicleta e aquilo mesmo que ele visa, a saber: o conhecimento de como se anda numa bicicleta: "É no próprio ato de andar de bicicleta que está contido o conhecimento exato do procedimento que se realiza quando se anda de bicicleta” (Ibidem). O mesmo ocorre no campo do conhecimento. Aí, observa o médico alemão (Ibidem, p. 314), "nós tomamos de empréstimo toda espécie de falso caminho até o momento onde nós adquirimos, enfim, uma imagem 'apropriada"'. Goldstein (Ibidem, p. 313314) não deixa de notar, portanto, a analogia entre conhecimento biológico e o aprendizado de uma prática: "o conhecimento biológico que nós procuramos é intimamente aparentado à adequação progressiva do poder do organismo e das condições do meio”.

A despeito da afirmação do parentesco entre o conhecimento biológico e a atividade de adaptação do organismo ao meio, Goldstein parece não levar até as últimas consequências a pesquisa sobre gênese vital das nossas categorias cognitivas, permanecendo no limiar que separa pensamento e vida. Ultrapassar esse limite em direção à identificação entre o ato 
criador da ideia de organismo e o ato pelo qual o vivente reage às condições do meio constitui uma das contribuições maiores da experiência filosófica de Canguilhem.

A direção da ultrapassagem intentada pelo filósofo fica patente na curiosa formulação citada acima: "o pensamento do vivente deve ter do vivente a ideia do vivente" $(1975$, p. 13, grifos nossos). Ora, porque não se contentar com um enunciado mais econômico, do tipo "o pensamento do vivente deve ter a ideia do vivente"? Por qual motivo é necessário insistir no fato de que se trata de uma ideia do vivente que pertence ao vivente? Queremos propor que a formulação mais econômica não conota suficientemente a relação de dependência da ideia em relação ao vivente, na medida em que ela não esclarece se a ideia pertence ao vivente ou se o vivente é que é apreendido pela ideia. Já a versão de Canguilhem, graças à aparente redundância, elimina essa ambiguidade, enfatizando que "o conceito de vivente é colocado pelo próprio vivente" (WORMS, 2008, p. 144).

No subsolo dos conceitos biológicos pretensamente objetivos, sob a aparente realidade das normas vitais, encontra-se, portanto, a polaridade normativa da vida ou, nas palavras de Canguilhem, um conceito axiológico que só pode ser colocado pelo próprio vivente: "todo conceito empírico de doença conserva uma relação ao conceito axiológico de doença (...). É sempre a relação ao indivíduo doente, por intermédio da clínica, que justifica a qualificação de patológico" (CANGUILHEM, 2007, p. 156). Daí porque o filósofo afirma o caráter técnico e subjetivo das categorias de saúde e de doença: elas são criações vitais pelas quais o organismo distingue, entre uma série de influências e condições de vida dadas, aquelas que vão constituir o seu próprio meio de existência. Em outras palavras, a afirmação do caráter técnico de categorias biológicas fundamentais implica na recusa da tese determinista segundo a qual os viventes se submetem passivamente às influências do meio geográfico. Assim como a criação técnica indicava, para Canguilhem, a possibilidade de ultrapassamento do fato pela procura e invenção de modos renovados de realização de exigências vitais, os conceitos axiológicos instituídos pelo vivente operam o ultrapassamento do meio pelo organismo, que adquire uma independência relativa frente às condições ambientais. A concepção canguilhemeana da subjetividade e tecnicidade dos conceitos biológicos leva a uma profunda recompreensão da maneira pela qual o pensamento científico positivista definia as relações entre o meio e o vivente.

\section{Uma teoria biológica do meio}


Os elementos centrais dessa teoria biológica do meio são apresentados na conferência Le vivant et son milieu, realizada, juntamente com Machine et organisme, no ano escolar de 1946-1947, no Collège International de Philosophie. Nela, Canguilhem coloca em questão a concepção mecanicista do meio, que a biologia tomara emprestada, juntamente com o termo, da física oitocentista. $\mathrm{O}$ meio era então representado como uma reta ou como um plano indefinidamente extensíveis, contínuos e homogêneos, em que qualquer posição privilegiada se convertia, tal como pensava Comte, numa função determinável pelas variáveis ${ }^{43}$. Eis o que, segundo Canguilhem, justifica "o prestígio da noção de meio para o pensamento científico analítico. O meio se torna um instrumento universal de dissolução de sínteses orgânicas individualizadas no anonimato dos elementos e dos movimentos universais" (1975, p. 134).

Com efeito, coube às ciências, na leitura canguilhemeana, levar a cabo a desvalorização da qualidade dos objetos que constituem o meio de vida humano, a fim de propor uma teoria geral do meio real ${ }^{44}$, isto é, não biológico. Desvalorizar consiste precisamente aqui em subtrair um valor, cuja fonte não é outra que o próprio vivente, para determinar leis de relações entre objetos válidas independentemente de qualquer referência a um centro produtor de significações. Com isso, "os dados sensíveis são desqualificados, quantificados, identificados. (...) as medidas se substituem às apreciações, as leis aos hábitos, a causalidade à hierarquia e o objetivo ao subjetivo" (1975, p. 153).

Uma ruptura com esta perspectiva hegemônica de compreensão das relações entre o organismo e o meio, Canguilhem encontra, particularmente, na etologia de von Uexküll e nas pesquisas sobre patologia do sistema nervoso desenvolvidas por Goldstein ${ }^{45}$. O que esses

\footnotetext{
${ }^{43}$ Com efeito, na quadragésima terceira lição do seu Cours de philosophie positive, Comte afirma: colocado num sistema dado de circunstância exteriores, um organismo definido deve sempre agir de uma maneira necessariamente determinada; e, no sentido inverso, a mesma ação não poderia ser identicamente produzida por organismo verdadeiramente distintos. (...) O sistema ambiente sendo sempre bem conhecido, segundo o conjunto das outras ciências fundamentais, vê-se assim que o duplo problema biológico pode ser colocado, seguindo o enunciado mais matemático possível, nestes termos gerais: sendo dado o órgão ou a modificação orgânica, encontrar a função ou o ato, e reciprocamente (1908, p. 159).

${ }^{44}$ A qualificação de real, observa Canguilhem, "somente pode convir, a rigor, ao universo absoluto, ao meio universal de elementos e de movimentos afirmados pela ciência, cujo reconhecimento como tal se acompanha necessariamente da desqualificação como ilusões e erros vitais de todos os meios próprios subjetivamente centrados, aí compreendido aquele do homem" (1975, p. 153).

${ }^{45}$ Há um outro domínio teórico importante para a fundamentação da crítica de Canguilhem às teorias deterministas do meio: trata-se da geografia humana e da teoria dos "gêneros de vida" de Vidal de la Blache e de Lucien Febvre. "Canguilhem souligne que, pour Vidal de La Blache et l'école française de géographie humaine, le milieu ne fait que présenter à l'homme des possibilités, il ne lui impose rien. Ce n'est pas la nature que implique tel genre de vie, ce sont au contraire les genres de vie de l'homme qui impliquent 'la nature telle que nous la voyons"' (BRAUSTEIN, 2011, p. 124). As referências a essa "escola francesa de geografia humana" se encontram desde os anos 1930, em particular no opúsculo Le facisme et les paysans, de 1935, redigido por Canguilhem, mas publicado anonimamente no quadro das produções do Comité de Vigilance des Intellectuels Antifascistes. Neste texto, a referência às teorias geográficas de Vidal de La Blache cumprem um papel importante na retomada das concepções marxistas, renovando-as à luz do desenvolvimento da atividade técnica e
} 
autores perceberam, segundo o filósofo, é que o meio de vida de um vivente não é um universo desqualificado, neutro, absoluto, mas “(...) é estruturado, organizado, pelo próprio organismo. O que o meio oferece ao vivente é função da demanda (1975, p. 152).

No caso de von Uexküll, esse modo de relação é pensado a partir da distinção entre Welt, o meio desqualificado das ciências, Umwelt, o meio de comportamento próprio de um animal determinado, e Umgebung, o meio geográfico. A diferenciação entre Umgebung e Umwelt assenta-se sobre a não identificação entre a totalidade dos excitantes presentes no meio geográfico geral e o conjunto dos excitantes que possuem valor e significação para o organismo. Afirmar essa diferença é, ao mesmo tempo, afirmar a irredutibilidade do vivente ao meio, seu caráter ativo como produtor de sentido, e recusar a concepção mecanicista de que o organismo vivo se deixa passivamente determinar pela ação do meio. Como observa Canguilhem:

\begin{abstract}
Para agir sobre um vivente, não é suficiente que a excitação física seja produzida, é necessário que ela seja notada. Por conseguinte, na medida em que ela age sobre o vivente, ela pressupõe a orientação do seu interesse, ela não procede do objeto, mas dele. Em outras palavras, é necessário, para que seja eficaz, que ela seja antecipada por uma atitude do sujeito. Se o vivente não procura, ele nada recebe. Um vivente não é uma máquina que responde por movimentos às excitações, é um maquinista que responde aos sinais por operações. (...) A questão está [para o biólogo] no fato de que da exuberância do meio físico, enquanto produtor de excitações cujo número é teoricamente ilimitado, o animal apenas retém alguns sinais. Seu ritmo de vida ordena o tempo desta Umwelt, como ele ordena o espaço (1975, p. 144-145).
\end{abstract}

No caso de Goldstein, a sua teoria das relações entre o organismo e o meio se constrói a partir de uma crítica à concepção mecânica do reflexo.

Por um longo período, que vai do final do século XIX até meados do século XX, a reflexologia mecanicista forneceu às diversas psicologias o quadro hegemônico de intelegibilidade de toda espécie de comportamento ${ }^{46}$. Com efeito, desde a fisiologia do sistema nervoso de Sherrington até a psicologia americana do comportamento e da aprendizagem, a conduta era compreendida como um conjunto de reflexos elementares ${ }^{47}$. Em

das suas cosequências para a transformação do meio geográfico humano (sobre essa questão, ver a apresentação de Michele Cammelli à Le facisme et les paysans. In: CANGUILHEM. Oeuvres complétes: tome I: écrits philosophiques et politiques 1926-1939. Paris: Vrin, 2011, p. 515-533).

${ }^{46} \mathrm{O}$ impacto dessa teoria no meio intelectual da época, particularmente no ambiente filosófico, pode ser atestado pela grande quantidade de autores que se dedicaram a refletir criticamente sobre seus princípios e implicações. Lembremos de obras fundamentais como, por exemplo, Essais sur les données imédiats de la conscience, de Bergson, La structure du comportement, de Merleau-Ponty, La formation du concept de réflexe, de Canguilhem, e $A$ estrutura do organismo, de Goldstein.

${ }^{47} \mathrm{Na}$ sua tese de doutoramento em filosofia, La formation du concept de reflèxe, Canguilhem insistirá na tese de que a reflexologia mecanicista, partidária da concepção determinista de meio, é incapaz de dar conta daquilo 
outras palavras, a unidade elementar na qual todo comportamento deveria ser analisado era o reflexo, entendido, à maneira clássica, como "a operação de um agente físico ou químico definido, sobre um receptor localmente definido, que provoca, por um trajeto definido, uma resposta definida" (MERLEAU-PONTY, 2002, p. 7). Nessa tese, nota Bimbenet, "vê-se exprimir, num mesmo movimento, um método de análise elementar e um realismo causal: o reflexo é ao mesmo tempo um conjunto de fatos exteriores uns aos outros e um conjunto de mecanismos" (2004, p. 48).

Contra a teoria do reflexo, os seus críticos defendiam que as variáveis das quais dependem os comportamentos biológicos não se encontram dadas no mundo físico, na forma de estimulações isoladas, mas são relações elaboradas pelo próprio organismo: "o stimulus adequado não pode se definir em si e independentemente do organismo; não é uma realidade física, é uma realidade fisiológica ou biológica" (MERLEAU-PONTY, 2002, p. 31). Isso quer dizer ao menos duas coisas: em primeiro lugar, que os estímulos consistem numa configuração perceptiva, numa forma, no sentido que a Gestalt atribui a esta noção: uma totalidade "cujas propriedades não são a soma daquelas que possuiriam as partes isoladas"; segundamente, que o meio de vida de um organismo é mais propriamente um "ambiente de comportamento", ou seja, uma situação preparada pelo organismo em função de exigências vitais, do que um "ambiente geográfico" composto por elementos reais.

Do mesmo modo que os estímulos, a reação do organismo apenas pode ser compreendida em termos de forma ou de totalidade: elas "não são edifícios de movimentos elementares, mas gestos dotados de uma unidade interior" (Ibid., p. 140), comportando "uma inteligibilidade imanente" (Ibid., p. 140). A unidade estrutural do comportamento é comparada "à uma melodia cinética, já que toda mudança no fim de uma melodia, modifica qualitativamente o começo e a fisionomia do conjunto" (Ibid., p. 109).

Por não admitirem que o comportamento é uma unidade formal, os psicólogos comportamentais americanos e os psicofisiologistas não tiveram sucesso em explicar a fixação de condutas bem sucedidas, nem, tampouco, o abandono daquelas que fracassaram. Pois se, admitindo o modelo mecanicista partilhado por esses teóricos, não vermos no comportamento senão uma série de acontecimentos exteriores entre si, então fica por explicar como o sucesso ou o fracasso do animal em realizar um objetivo é capaz de fixar ou de dissolver o conjunto de ações que o antecederam.

que, nos comportamentos, escapa ao modelo de explicação por análise reflexa, fazendo intervir algum poder de comando do vivente. 
É a esse problema que Goldstein pretende oferecer uma solução a partir da ideia de comportamento privilegiado. Para o neurologista alemão, os modos privilegiados de comportamento são aqueles preferidos pelo organismo no conjunto de todos os seus comportamentos possíveis (GOLDSTEIN, 1983, p. 287). Tal preferência por determinadas posições, movimentos ou percepções, se caracteriza pelo "sentimento de maior 'comodidade', de maior 'simplicidade' e de maior exatidão da operação" (Ibidem, p. 291). À essa característica subjetiva, segue-se uma marca objetiva das formas privilegiadas de reação: elas são "a melhor operação, a mais adequada, aquela que corresponde melhor à tarefa" (ibidem, p. 305). Em outras palavras, "(...) no comportamento privilegiado, o organismo chega a um compromisso, mais adequado e mais conforme a sua essência, com uma dada situação do mundo exterior" (ibidem, p. 305). Os comportamentos "não privilegiados" ou catastróficos se caracterizam, ao contrário, pelo "sentimento de 'incorreção', de 'incômodo', de 'insatisfação', de 'dificuldade, de 'arbitrariedade' (...)" (ibidem, p. 295).

A distinção entre comportamentos privilegiados e comportamentos catastróficos só pode se estabelecer desde que se tenha ultrapassado o atomismo comportamental defendido pela reflexologia em direção a uma compreensão global, isto é, totalizante das reações vitais. Isso porque, para Goldstein, o organismo deve ser pensado como uma estrutura, ou seja, como uma totalidade cujas partes se acham reunidas em função de um princípio interno de organização, de maneira que "as modificações que nós podemos constatar em diferentes lugares nunca são independentes umas das outras; ao contrário, elas mantêm umas com as outras uma relação totalmente determinada. Elas constituem uma unidade bem integrada" (1983, p. 179)

Essa integração entre as modificações particulares na estrutura orgânica que as envolve se revela, como observa Goldstein, no caso do comportamento patológico, afinal ele "não se manifesta somente em certos transtornos funcionais determinados segundo a localização do déficit, mas de forma mais geral porque, como nós vimos, um comportamento desordenado representa sempre um comportamento mais ou menos desordenado de todo o organismo" (1983, p. 345-346). Quando, portanto, um vivente adoece é uma outra forma [allure] de vida que se constitui, de modo que certos comportamentos, antes possíveis, tornam-se agora totalmente irrealizáveis nas mesmas circunstâncias.

Há, portanto, uma real diferença de valor entre comportamentos que não pode ser apreciada objetivamente a partir da mensuração e comparação de constantes fisiológicas. Ao contrário, ela se dá primeiramente como objeto de uma avaliação individual, pois só o 
organismo singular é capaz de julgar a qualidade propulsiva ou repulsiva da sua forma de vida em relação às exigências do meio em que vive. Se Canguilhem nunca deixa de insistir que “objetivamente, apenas se pode definir variedade ou diferenças, sem valor vital positivo ou negativo" (2007, p. 153), é porque ele entende que esse valor se revela apenas no modo próprio de relação entre o vivente e o meio, que o filósofo, mais uma vez na esteira de Goldstein, designa como um debate [Auseinandersetzung]:

Com efeito, a vida não é para o vivente uma dedução monótona, um movimento retilíneo, ela ignora a rigidez geométrica, ela é debate ou explicação (o que Goldstein chama de Auseinandersetzung) com um meio em que há fugas, falhas, subterfúgios e resistências inesperadas (CANGUILHEM, 2007, p. 131).

Não é demasiado afirmar que a noção goldsteineana de debate é o saldo principal da contribuição do neurologista alemão para uma teoria renovada do meio. Isso porque Goldstein fora capaz de perceber o caráter dinâmico e conflitual da relação entre o organismo e o seu ambiente, ambos se constituindo correlativamente ao longo do desenrolar desse debate, sem que haja precedência ou subordinação de um frente ao outro.

\section{Valorar é julgar: a potência vital de julgamento}

Ao elevar a forma debate a modo geral de relação entre os organismos e o meio, Canguilhem está afirmando a existência, mesmo nos seres vivos mais simples, de uma potência de julgar ${ }^{48}$ por meio da qual o vivente, como vimos à propósito das teorias de Goldstein, constitui seu próprio meio de existência ao avaliar as excitações disponíveis num meio mais amplo, selecionando-as. Em páginas centrais do seu curso de 1942-1943, lemos:

Todo julgamento é separação, sem dúvida, mas também ordenação e hierarquização.
Quando eu julgo que um lugar é distante, nada afirmo de absoluto, mas
simplesmente que tal lugar é mais longe do que um outro ao meu alcance; ou que ele
é distante em relação a certos meios de locomoção. Julgar o distante e o perto é
ordenar o espaço em relação a um corpo móvel, é mais do que simplesmente medir,
é constituir uma hierarquia topográfica, é claramente avaliar. Se nós admitimos, de
acordo com a sugestão etimológica, que julgar é discriminar e avaliar, por que
recusaríamos o julgamento a uma ameba ou mesmo a um vegetal? Por todos os
lugares em que existe vida, isto é, constituição de meios orgânicos e funcionais

\footnotetext{
${ }^{48}$ Não seria possível, neste trabalho, desenvolver o que poderíamos chamar de uma teoria canguilhemeana do juízo, o que demandaria uma pesquisa aprofundada em duas fontes fundamentais: nos cursos, particularmente na seção VIII, "l'analyse des choses: concept, jugement, langage et intelligence", do curso Psychologie, Valenciennes, 1934-1935; curso Logique, 1944, Strasbourg, à Clermond-Ferrand, última parte: "Problème des rapports du concept et du jugement; dentre outros.
} 
visando manter uma forma relativamente independente das condições de existência exterior, ou seja, de selecionar o meio, ao invés de sofrer passivamente a seleção do meio, há discernimento e escolha, então há julgamento. Porque a consciência relativa da qual ele goza permite ao homem construir uma teoria do julgamento, disso não se segue que a potência de julgar comece nele e seja recusada aos outros viventes (1942-1943, p. 133, grifos nossos).

Identificar a potência de julgar à capacidade de criar normas parece um contrassenso frente a uma concepção clássica de julgamento, para a qual esse ato é "identificado a uma operação de caráter lógico e teórico que tem por efeito o reconhecimento de realidade ou de fatos, enquanto que o termo norma é reservado a operações de criação ou de conduta" (CANGUILHEM, 1950, p. 6). Em Kant, por exemplo, julgar é um poder exclusivamente humano pelo qual nos é possível reunir representações sob categorias a priori capazes de garantir a objetividade daquelas e, por conseguinte, do nosso conhecimento a respeito do mundo.

A crítica canguilhemeana à identificação do julgamento a uma operação lógica de recognição da realidade se fará a propósito do debate, disseminado na França desde o século XIX, sobre o estatuto da moral como ciência normativa. Para os seus defensores, as prescrições morais teriam valor normativo na medida em que elas se assentariam sobre a objetividade dos fatos morais tratados como se fossem fatos naturais ${ }^{49}$. Afirmar tal possibilidade, no entanto, significa assumir dois pressupostos: o primeiro é o de que a moral seria um fato natural, como os fenômenos com os quais o físico e o químico trabalham; o segundo é o de que a descrição desse fato em termos de lei seria capaz de prescrever a lei do agir moral, como se a determinação de relações causais no campo da moral fornecesse parâmetros para o controle e para a orientação das condutas. Contra tal pretensão, Canguilhem afirma:

\begin{abstract}
Não há ciência normativa. Não se tem nenhum interesse de reivindicar para o julgamento de prescrição a forma do julgamento científico, enquanto não se estabeleceu que a forma do julgamento científico é a única forma válida ou validável de julgamento. Mas é fácil ver que o exame desse problema exige que o ponto de vista científico seja ultrapassado. Validar o julgamento científico é tornar o julgamento científico dependente do julgamento de valor. Ora, as ciências normativas se propunham o inverso (Ibidem, p. 22).
\end{abstract}

\footnotetext{
${ }^{49}$ No Traité de logique et de morale, Canguilhem e Planet defendem a tese de que a moral não é o resultado de uma investigação científica da realidade, mas uma criação da consciência humana e, portanto, mais um valor do que um fato: "Il faut bien compreendre que la conscience morale c'est avant toue une conscience créatrice d'ellemême ou encore progressive (...). Autrement dit, la conscience morale a cette valeur d'être perpétuellement à la recherche de ce qu'elle n'est pas en fait, et de ce qu'elle ne saurait être d'une façon durable" (In: CANGUILHEM. Oeuvres complétes: tome I: écrits philosophiques et politiques 1926-1939. Paris: Vrin, 2011, p. 822 , grifos nossos).
} 
Nesse sentido, dizer que julgamentos normativos se fundamentam em juízos de realidade é esquecer que tal proposição só é possível porque ela supõe exatamente o contrário do que deseja concluir: se o julgamento científico se converteu na norma do julgar é porque esse valor lhe foi atribuído, não por um julgamento científico anterior ou mais primitivo, mas por um julgamento normativo. É por essa razão que, como vimos anteriormente, a identificação entre a normalidade e a generalidade reclama, seja para Comte seja para Durkheim, a suposição de uma filosofia realista que, ao afirmar que a generalidade é normal porque exprime uma perfeição essencial, funda o julgamento científico de normalidade sobre um ideal ontológico de perfeição. A ideia de que o valor de um julgamento assenta-se num sujeito substancial, portador de atributos essenciais, será criticada por Canguilhem, que buscará numa filosofia da vida, e não numa ontologia, o fundamento de uma teoria do valor. Mas, antes disso, é preciso que o filósofo defenda a prioridade dos julgamentos normativos sobre os julgamentos científicos, como ele próprio afirma, na lição Logique et science, do curso Les normes et le normal: "Que um julgamento científico seja um julgamento de valor, isso não é um paradoxo para quem compreendeu a relevância dos desmembramentos que produziram para o realismo epistemológico as crises e as revoluções da matemática e da física no século XIX” (1942-1943, p. 23).

Certamente é ao seu professor Bachelard que Canguilhem se refere nessa citação. Com efeito, desde La valeur inductive de la relativité, Bachelard procurava extrair as implicações da teoria da relatividade geral para uma ampla reconfiguração da epistemologia da física, dominada, até então, pela hegemonia da perspectiva realista, cujo maior representante na França era Émile Meyerson. Este, em 1925, publicava o seu La déduction relativiste, obra na qual afirmava que o real, na teoria da relatividade, seria "um absoluto ontológico, um verdadeiro ser-em-si, mais absoluto e mais ontológico ainda que as coisas do senso comum e da física pré-einsteiniana" (MEYERSON, 1925, p. 79).

Não cabe a esta dissertação seguir detalhadamente o desenvolvimento da crítica bachelardeana a essa tese. Contudo, para o que nos interessa, vale destacar que, segundo Bachelard, o advento da física contemporânea traz consigo um problema filosófico de amplo alcance: no mundo microfísico do corpúsculo é ainda possível falar em fatos, em coisas? A resposta de Bachelard, Canguilhem a resume: 
verdadeiramente - aos olhos de Bachelard, procurar as bases de um comentário ativo e atual das maneiras de operar e dos modos de pensar do físico do período pósmaxwelleano (1975b, p. 190).

Para Bachelard, com efeito, no domínio do ultramicroscópico, nem a mais acurada análise alcança um objeto único: o real se desindividualiza fisicamente, o individual não é mais o substancial, pois "a substância do infinitamente pequeno é contemporânea da relação" (BACHELARD, 2008, p. 13). Em outra passagem, o epistemólogo dirá com maior ênfase: "Antes de tudo, convém reter que o plano numênico do microcosmos é um plano essencialmente complexo. Nada mais perigoso que postular sua simplicidade, a independência dos seres, ou até a sua unidade. Convém aí inscrever antes de tudo a Relação" (BACHELARD, 2008, p. 18).

O domínio dos fatos empíricos imediatamente apreendidos pela intuição não é mais capaz de fornecer à física contemporânea o fundamento seguro para o desenvolvimento das suas teorias. Entre o fato, como realidade aqui e agora, e a realidade enquanto horizonte normativo para o desenvolvimento da ciência há uma cisão que só pode ser superada pelo pensamento que não teme destruir as impressões aparentemente mais evidentes. Como afirma Bachelard em La philosophie du nom: "As intuições são muito úteis: eles servem para ser destruídas" (1940, p. 139). O estilhaçamento desses esquemas elementares fornecidos pela sensibilidade se faz pelo processo de conceitualização, no desenrolar do qual conceitos cada vez mais gerais são criados a partir da purificação dos conceitos elementares do conteúdo derivado da intuição imediata. Daí porque, defende Bachelard,

\footnotetext{
a conceitualização será um esforço de objetividade mas, tudo bem considerado, ela vai desenvolver-se em sentido inesperado, pois para a depuração do conceito não é o objeto que chama (...), mas é o espírito que projeta esquemas multiplicados, uma geometria, um método de construção e até um método de retificação (1928, p. 27).
}

Em síntese: realidade é o termo ou o ideal do conhecimento científico, não seu ponto de partida: “A maior realidade não está ligada às primeiras constatações feitas sobre uma figura particular imediatamente apreendida. Bem ao contrário: a maior realidade das ideias se acha do lado da maior generalidade obtida por uma intuição muito trabalhada" $(1949$, p. 91). E essa generalização na forma de mundo ou de realidade, cuja força teleológica coloca em marcha o processo de conceitualização, é o que confere ao conhecimento o seu caráter normativo: "o pensamento especulativo tende a tornar-se normativo". 
De posse dessas teses gerais de Bachelard, torna-se mais facilmente compreensível a afirmação de Canguilhem à Dominique Parodi: "Se o pensamento vai ao real e não parte dele (Bachelard), é necessário tomar a realidade como um valor possível do julgamento" (2011, p. 499). A inversão entre julgamentos de valor e julgamentos de realidade, de maneira a assentar os segundos sobre os primeiros, tem como consequência maior a desidentificação entre o poder de julgar e as faculdades cognitivas reguladas pelas categorias lógicas. Como observa Benmakhlouf:

Quando se interpreta o julgamento como discernimento, isto é, como instituição de uma hierarquia nas qualidades que nascem do encontro de um vivente e das suas condições de vida, não há espaço para recusar o julgamento a qualquer vivente que seja. Esse julgamento não é claramente lógico; ele não é regido pelo princípio de identidade, mas pelo princípio da diferença ou da não-identidade (2000, p. 84).

A extensão da potência de julgar à totalidade dos viventes alimentou acusações como a de que Canguilhem teria sucumbido à tentação de tomar a via do antropomorfismo para explicar os comportamentos biológicos mais fundamentais. Ao contrário do que alguns insistem em defender, queremos mostrar que não é esse o caso do vitalismo canguilhemeano. Trata-se, antes, de afirmar a gênese vital de tudo quanto se nos apresenta como inerente à essência do humano. Ciente de tais objeções, Canguilhem se adianta a respondê-las:

\footnotetext{
Nós pensamos estar tão atentos quanto quaisquer outros para não sucumbirmos à tendência de cair no antropomorfismo. Não emprestamos às normas vitais um conteúdo humano mas gostaríamos de saber como é que a normatividade essencial à consciência humana se explicaria se, de certo modo, já não estivesse em germe na vida (2007, p. 77).
}

Longe de incorrer numa simples identificação entre o humano e os seres vivos menos organizados, Canguilhem pretende colocar em questão a existência de uma cisão radical entre natureza e cultura, entre o biológico e o humano, revelando a permanência de um germe vital naquilo que estamos habituados a reconhecer como o horizonte normativo da humanidade do homem. Para o filósofo francês, a exigência fundamental consiste então em "assumir a tarefa de pensar este germe, isto é, a vida aquém da constituição desta normatividade essencial da consciência humana que nós podemos chamar de 'normatividade social'" (SAFATLE, 2011, VI Colóquio Internacional Michel Foucault).

Assim, o que muitos críticos não compreenderam, é que a potência de julgar só pode ser atribuída a todos os viventes porque neles Canguilhem explicita uma potência de avaliar: a vida não é evolução criadora, mas avaliação criadora (1941, p. 1, verso). Eis porque, para se 
entender o verdadeiro sentido dessa atribuição, o passo seguinte consiste em precisar a relação que Canguilhem estabelece entre o vivente e a potência de valorar.

\section{Individualidade orgânica e normatividade vital}

$\mathrm{Na}$ parte anterior, vimos como Comte e Claude Bernard pretendiam fundar juízos médicos normativos sobre o normal biológico concebido como um fato real, apreensível pelo conhecimento humano a partir de procedimentos de cálculo e de mensuração. O mesmo se passava com a sociologia durkheimeana, para a qual a normalidade social se identificava à generalidade de certos fenômenos. Assim, reduzindo as normas a um fato quantitativamente definível, perder-se-ia de vista a verdadeira relação que mantém entre si as normas e a vida, e que toma a forma de uma polaridade axiológica:

E, porém, para não ceder ao prestígio de uma explicação por redução (que é o tipo de explicação no sistema de realidade), para não reduzir os valores e as normas aos dados de fato da experiência biológica, para, ao contrário, procurar a significação da vida encontrando, nela mesma, na sua ordem específica de exercício, a relação fundamental de polaridade axiológica, para isso é uma filosofia da vida que fornece os fundamentos de uma filosofia das normas (1962-1963, p. 38, grifos nossos).

Fundar uma filosofia das normas sobre uma filosofia da vida não constitui apenas, como veremos, uma recusa do reducionismo dos valores e das normas aos fatos empíricos, mas também do reducionismo a uma ontologia. Lembremos da ontologia da regularidade que Canguilhem coloca à luz sob as explicações durkheimeanas e comteanas para o fenômeno da generalidade dos fenômenos sociais e biológicos. Em ambos os casos, tratava-se de fundar o valor da normalidade sobre um fato: a essência real, que se exprimia naqueles fenômenos mais gerais. Porém, a filosofia da vida de Canguilhem, como pretendemos mostrar, não é uma ontologia da vida, no sentido de que a vida seria aí concebida sob a forma de uma substância portadora de certos atributos dos quais as normas seriam como que as atualizações, mas uma filosofia para a qual a vida só pode ser pensada como produtora de indeterminações, como negação de identidades fixas para a produção de novas normas vitais. Essas ideias fundamentais da concepção canguilhemeana da vida podem ser traduzidas na noção de “negação afirmativa”, que Macherey $(2008$, p. 72) utiliza para se referir à expressão "da fundamental impulsão a perseverar no seu ser que está em cada vivente, e que se assinala então tomando as formas do protesto e da recusa" (Ibidem, p. 72). 
Assim, para ser capaz de fundamentar uma filosofia das normas sem incorrer no reducionismo empírico ou ontológico, essa filosofia da vida deve assumir uma nova perspectiva: "esse ponto de vista novo é aquele da normatividade vital" (CANGUILHEM, 2007, p. 84):

Por normativo, entende-se em filosofia todo julgamento que aprecia ou qualifica um fato relativamente a uma norma, mas esse modo de julgamento é, no fundo, subordinado àquele que institui normas. No sentido pleno da palavra, normativo é o que institui normas. E é nesse sentido que nós propomos falar de uma normatividade biológica (Ibidem, p. 77).

Enquanto que Durkheim, Comte e Claude Bernard se esforçavam para eliminar do ato de julgar qualquer referência à subjetividade que julga, de modo a fazer do julgamento o mero ato de comparar um caso com uma norma métrica objetiva, a noção de normatividade recupera a ideia de que o julgamento é um ato "subordinado àquele que institui normas" (Ibidem, p. 77). Note-se bem: para Canguilhem, o julgamento do normal e do patológico não se subordina à norma enquanto fato determinável por procedimentos de comparação e quantificação, mas à subjetividade que institui normas. Depois, será o caso de compreendermos o que Canguilhem entende nesse momento por subjetividade; por ora, importa-nos dizer que, para o filósofo, a vida é o sujeito por excelência do ato de julgar, posto que viver é avaliar, ou seja, preferir e excluir, assimilar e recusar, atribuir valores positivos e negativos. Na sua tese de doutoramento, o filósofo repete incansavelmente que "a vida está bem longe de uma tal indiferença às condições que lhe são feitas, a vida é polaridade. $\mathrm{O}$ mais simples aparelho biológico de nutrição, de assimilação e de excreção traduz uma polaridade" (ibidem, p. 79); e, na sequência, conclui: “É precisamente o único fato a respeito do qual pedimos que concordem conosco. Não há indiferença biológica. Por isso, pode-se falar em normatividade biológica. Há normas biológicas sãs e normas patológicas, e as segundas não possuem a mesma qualidade das primeiras" (Ibidem).

$\mathrm{Na}$ primeira parte da dissertação, acompanhamos o diagnóstico canguilhemeano de que a identificação entre generalidade e normalidade se sustentava, em Durkheim e Comte, sobre uma certa filosofia realista para a qual a regularidade dos fenômenos exprimia a perfeição de uma essência vital ou social. Essa era uma maneira astuta de eliminar a diferença qualitativa entre a saúde e a doença pela afirmação de que o normal exprime numericamente uma essência real. Sendo assim, a possibilidade de criação de normas se limita de antemão à atualização de potencialidades desde sempre contidas nessa essência. A perspectiva da normatividade vital, porém, não permite que a vida seja pensada como uma essência que se 
realizaria na regularidade das normas biológicas, compreendendo-a, ao contrário, como um movimento de ultrapassamento de formas estabilizadas de organização, como bem resume Macherey:

\begin{abstract}
Falar de normatividade é, ao invés de considerar a realização das normas como a aplicação de um poder mecânico pré-constituído, mostrar como o movimento concreto das normas, que são esquemas vitais à procura das condições da sua realização, elabora ao fim e ao cabo do seu desenvolvimento esse poder que ele produz sob o plano da sua forma e, ao mesmo tempo, do seu conteúdo. A vida cessa de ser então uma natureza substancial para se tornar um projeto, no sentido próprio deste impulso [élan] que a desequilibra, projetando-a sem cessar para além dela mesma, arriscando vê-la, nos seus momentos críticos, tropeçar nos obstáculos que se opõem ao seu avanço (2008, p. 74 , grifos nossos).
\end{abstract}

Enquanto projeto ou improvisação, a vida se constitui à medida em que cria normas de relação com o meio. Somente porque é atividade valorativa que a vida pode distinguir qualitativamente entre estados biológicos. Como já observamos acima, não há fenômenos físicos normais e patológicos, o que se deixa perceber, por exemplo, na mecânica moderna que, sustentada sobre o princípio de inércia, tornou absurda a velha diferenciação aristotélica entre movimentos naturais e movimentos violentos, reduzindo esses últimos a variações quantitativas dos primeiros. Contudo, não obstante o projeto de Durkheim, Comte e de Claude Bernard de identificar o normal e o patológico, é preciso reconhecer que

o fato, para um vivente, de reagir por uma doença a uma lesão, a uma infestação, a uma anarquia funcional traduz o fato fundamental que a vida não é indiferente às condições nas quais ela é possível, que a vida é polaridade e por isso mesmo posição inconsciente de valor, em suma, que a vida é de fato uma atividade normativa (2007, p. 77).

Afirmar o caráter normativo de todo fenômeno mórbido é colocar em questão a sua identificação com a anormalidade ${ }^{50}$. De fato, ao invés de se compreender o patológico como o estado do qual toda norma está ausente, Canguilhem insiste que "a doença é ainda uma norma de vida, mas uma norma inferior no sentido de que ela não tolera nenhum desvio das condições nas quais ela vale, incapaz que é de se transformar em uma outra norma" (2007, p. 120). Nesse sentido, pode-se dizer que um vivente está doente quando se encontra fixado a

\footnotetext{
${ }^{50}$ Porém, desde que se compreenda o adjetivo anormal como designando uma normatividade limitada de vida, é possível afirmar que o patológico é o anormal. "No entanto, por mais prevista que possa parecer, não podemos deixar de admitir que a doença é prevista como um estado contra o qual é preciso lutar para continuar a viver, isto é, que ela é prevista como um estado anormal, relativamente à persistência da vida que exerce aqui o papel de norma. Então, tomando a palavra normal no seu sentido autêntico, nós devemos colocar a equação entre os conceitos de doença, patológico e anormal” (2007, p. 86).
} 
uma única forma de vida, tendo perdido a sua capacidade normativa, isto é, a capacidade de instituir novas normas. Eis a situação que Canguilhem constata nas descrições clínicas que Goldstein elabora a respeito dos seus pacientes atingidos por lesões cerebrais. Em todos eles, nota-se a instauração de uma norma reduzida de vida, cujo efeito mais imediatamente observável consiste na transformação do modo de reação do organismo frente ao seu meio. $\mathrm{O}$ aparecimento do que, mais acima, vimos Goldstein chamar de reações catastróficas é um índice de que o organismo foi modificado de tal maneira que ele já não consegue mais responder a determinadas exigências do seu ambiente de vida, desenvolvendo uma série de desordens que atingem a totalidade dos seus comportamentos. Do lado de outra tradição clínica, Leriche, segundo expusemos, também afirmava que a dor não era um fenômeno biológico compreendido em termos de variações quantitativas de excitação em uma determinada região anatômica, mas resultava da atividade criadora, normativa, do vivente, o que se tornava patente no citado caso de um paciente com osteoartrite tuberculosa do joelho.

É, sobretudo. dessas observações de Goldstein e de Leriche que Canguilhem extrai uma tese fundamental: a doença é um fenômeno de relação. Isso quer dizer que longe de ser um estado determinável em termos de uma normalidade fixada de antemão por meio de cálculos estatísticos e tabelas de quantificação, a patologia é ela mesma uma norma que, enquanto tal, só pode ser apreciada como uma resposta inovadora aos problemas que a suscitaram: "o doente deve ser sempre julgado em relação com a situação à qual ele reage e com os instrumentos de ação que o meio próprio lhe oferece (...). Não há transtorno patológico em si, o anormal somente pode ser apreciado numa relação” (2007, p. 123).

De imediato, duas concepções de doença são assim afastadas: aquela de extração positivista que não reconhece no fenômeno mórbido senão uma variação quantitativa de estados normais precedentes; e uma outra, cujo impacto nas teorias antropológicas modernas é significativo, que concebe a doença como um processo de dissolução de funções superiores, ocasionando, como consequência, a regressão do organismo a estágios inferiores do desenvolvimento ontogenético ou filogenético. Contra elas, Canguilhem não cansa de insistir que, se “ (...) a doença é uma forma de vida encurtada, sem generosidade criativa já que sem audácia, não é menos verdadeiro que, para o indivíduo, a doença é uma vida nova, caracterizada por novas constantes fisiológicas, por novos mecanismos de obtenção de resultados aparentemente inalterados" (2007, p. 124, grifos nossos).

O que importa nesta passagem é o ponto de vista em que ela se situa para apreender a novidade normativa instituída pela doença: é a partir do indivíduo, e apenas segundo a sua 
perspectiva, que a patologia se revela como um outro estado, qualitativamente diferente do estado são que a antecedera. Comte e Claude Bernard, nas ciências da vida, assim como Durkheim, na sociologia, esforçaram-se para subtrair a distinção entre o normal e o patológico da avaliação de uma subjetividade vivente, isso para garantir a objetividade daqueles conceitos, reduzidos então a variações de quantidade de uma medida tomada como norma. É precisamente essa subjetividade biológica que Canguilhem pretende colocar como fundamento do conhecimento médico da saúde e da doença. Porém, cabe sublinhar que, com afirmações desse tipo, o filósofo não pretende tornar impossível a distinção entre a saúde e a patologia, como se, excluída a possibilidade de determinação objetiva das fronteiras entre esses estados, nada mais restasse que um absoluto relativismo. Como escreve o filósofo:

\begin{abstract}
A fronteira entre o normal e o patológico é imprecisa para indivíduos múltiplos considerados simultaneamente, mas ela é perfeitamente precisa para um único e mesmo indivíduo considerado sucessivamente. O que é normal, por ser normativo em condições dadas, pode se tornar patológico em uma outra situação, se ele se mantém idêntico a si. Dessa transformação, é o indivíduo que é o juiz porque é ele que dela padece, no momento mesmo em que ele se sente inferior às tarefas que a situação nova lhe impõe (2007, p. 119).
\end{abstract}

A entrada em cena do indivíduo como juiz dos diagnósticos clínicos não é um expediente inédito. Ele foi mobilizado, tanto por médicos quanto por psicólogos, em diferentes momentos da história desses saberes, toda vez que se procurou um critério de normalidade capaz de valer como horizonte normativo da clínica. Nesse caso, indivíduo era o nome que se dava à hipóstase de atributos como autonomia, autenticidade e unidade, os quais forneciam as normas gerais de orientação do diagnóstico e da terapêutica ${ }^{51}$, a doença sendo entendida como déficit ou excesso de um ou de vários desses atributos, e a cura, como o restabelecimento dos mesmos.

Para Canguilhem, todavia, o indivíduo não é da ordem dos entes ou das coisas, mas dos valores: "A biologia deve tomar então o vivente por um ser significativo, e a individualidade, não por um objeto, mas por uma característica na ordem dos valores. Viver é irradiar, é organizar o meio a partir de um centro de referência que não pode ser ele mesmo referido sem perder a sua significação original" (1975, p. 147). Na medida em que, como dissemos anteriormente, o sentido dos organismos não é um existente previamente dado então

\footnotetext{
${ }^{51}$ Evocamos, a título de exemplo, a maneira como a psiquiatria dos séculos XVIII e XIX descrevia o fenômeno da loucura em termos de um déficit de autonomia ou de alienação da vontade, consistindo o seu tratamento na recuperação da normalidade desse atributo. Para uma análise mais detalhada, consultar FOUCAULT, Michel. $O$ poder psiquiátrico. Trad. Eduardo Brandão. São Paulo: Martins Fontes, 2008.
} 
as individualidades biológicas não podem existir como significações a priori, mas como elaborações formadas ao longo do seu desenvolvimento em estreita relação com as condições do meio.

Daí, esta outra característica das individualidades biológicas: seu caráter relacional. "Em suma, a individualidade não é um termo se se entende por isso um limite, ela é um termo numa relação" (Ibidem, p. 71, grifos nossos). Afirmações como essas parecem nuançar o traço irredutível e absoluto do indivíduo biológico (Ibidem, p. 154), o que, nos termos de Lecourt, coloca o seguinte problema: "como conciliar o primado colocado da relação sobre o seu termo com a ideia que um desses dois termos, o indivíduo vivente, constitui, em cada ordem de grandeza, um centro de referência absoluto?” (1993, p. 265).

Uma resposta para essa questão não pode deixar de levar em conta a articulação entre Canguilhem e Darwin, sobretudo a maneira pela qual esse último concebe o meio do vivente como um "meio biogeográfico" (1975, p. 138). Canguilhem utiliza essa expressão para insistir no fato de que, segundo Darwin, a forma determinada de cada indivíduo é resultado de uma complexa trama de relações com indivíduos da mesma espécie, de espécies diferentes e com as condições do meio. O conhecido processo de seleção natural não seria assim uma instância transcendente e consciente de seleção de variações individuais, mas, ao contrário, um jogo de relações que determinariam, para cada circunstância, formas mais aptas à sobrevivência do que outras. Não se está assim incorrendo na velha concepção mecanicista de meio. O vivente não se restringe a um mero efeito de circunstâncias ambientais que o ultrapassariam, pois é forçoso reconhecer que também ele é capaz de configurar seu próprio meio de existência, como fica explícito no caso do vivente humano, cuja ação sobre as circunstâncias torna-se ainda mais eficaz graças à técnica. Além disso, a seleção natural opera sobre variações anatomofisiológicas que expressam normatividades inéditas, cuja gênese não pode ser o meio, mas o próprio vivente.

Então, desde que se reconheça que a normatividade vivente não é uma capacidade totalmente autônoma de uma singularidade subjetiva, mas um debate com outras normas, nada se denunciaria de contraditório em afirmar, simultaneamente, o primado das relações sobre os termos e a centralidade irredutível do indivíduo. Por isso que à noção de experiência individual, que, já na sua etimologia ${ }^{52}$, parece remeter irremediavelmente à ideia de entes atomizados sem nenhuma ligação efetiva a os unir, Macherey prefere pensar em termos de uma "experiência individuada" (1998, p. 76):

\footnotetext{
${ }^{52}$ Segundo Lecourt, "Cicéron introduit le vocable 'individuum' en latim pour désigner l'atome démocritéen" (1993, p. 263)
} 
Se há, sobre o plano da vida humana, individuação, é ao termo de um processo que produz indivíduos a partir de condições que não são estritamente individuais, no sentido em que elas não estão, desde o início, realizadas apenas no indivíduo, por que elas supõem a intervenção do meio humano em que prevalecem formas de existência que não são individuais, mas coletivas (Ibidem, p. 76).

O que o comentador diz a respeito da vida humana, pode-se facilmente estender para toda a forma de vida. É o próprio Canguilhem que nos sugere essa ampliação ao se remeter às pesquisas sobre a seleção natural em populações de borboletas, descritas por Georges Teissier, não por acaso um dos nomes mais conhecidos do darwinismo francês:

\begin{abstract}
Observou-se, em alguns distritos industriais da Alemanha e da Inglaterra, a desaparição progressiva de borboletas cinzas e o aparecimento de borboletas negras da mesma espécie. Ora, pode-se estabelecer que a coloração negra é acompanhada nas borboletas de um vigor particular. Em cativeiro, as negras eliminam as cinzas. Por que não ocorre o mesmo na natureza? Pois sua cor, se destacando mais sobre a casca das árvores, atrai mais a atenção dos pássaros. Quando nas regiões industriais, o número de aves diminui, as borboletas podem ser negras impunemente (2007, p. 90).
\end{abstract}

As mutações que levaram ao advento de variações individuais entre essa espécie de borboletas sofrem a interferência das condições ambientais, que reúnem a concorrência interespecífica, a existência de predadores de outras espécies (as aves) e as transformações induzidas no meio pela ação humana (a indústria). Dessa experiência, Canguilhem conclui que "a espécie seria o agrupamento de indivíduos, todos em alguma medida diferentes, e cuja unidade traduz a normalização momentânea das suas relações com o meio, aí compreendida com outras espécies, como Darwin bem viu" (Ibidem, p. 90). No limite, uma norma não é a mera expressão singular de uma autonomia e vontade individuais, como Durkheim já percebera ao se esforçar para afastar a redução do sociológico ao psicológico, tampouco é a realização de atributos essenciais, como sugere para Canguilhem a ideia durkheimeana de ontologia social, mas depende de uma estrutura complexa de relações que a precedem:

O vivente e o meio não são normais tomados separadamente, mas é sua relação que os torna tais um e outro. O meio é normal para uma forma vivente dada na medida em que ele lhe permite uma tal fecundidade, e correlativamente uma tal variedade de formas, que, na hipótese de ocorrerem modificações do meio, a vida possa encontrar numa dessas formas a solução ao problema da adaptação que ela é brutalmente obrigada a resolver. Um vivente é normal num meio dado na medida em que ele é a solução morfológica e funcional encontrada pela vida para responder a todas as exigências do meio. Relativamente a toda outra forma da qual ele se desvia, esse vivente é normal, mesmo se ele é relativamente raro, pelo fato de que ele é, em relação a ela normativo, isto é, que a desvaloriza antes de eliminá-la (2007, p. 91). 
Dessa maneira, as anomalias, mesmo aquelas que podem ser objetivamente detectadas por instaurarem, por exemplo, diferenças anatômicas visíveis, serão meras variações enquanto não forem sentidas negativamente pelo organismo individual. Em outras palavras, uma anomalia só se torna objeto do interesse científico quando ela se torna patológica. O caso limite das heterotaxias, estudadas por I. Geoffroy Saint-Hilaire, serve para mostrar que mesmo uma anomalia aparentemente grave do ponto de vista anatômico, na medida em que altera a relação entre as vísceras, pode permanecer por longo tempo desconhecida do doente. Para Canguilhem, isso revela que

\begin{abstract}
a anomalia é ignorada na medida em que ela é sem expressão na ordem dos valores vitais. Assim, segundo a confissão mesma de um cientista, a anomalia apenas é conhecida pela ciência se ela inicialmente foi sentida na consciência, sob forma de obstáculo, ao exercício das funções, sob forma de perturbação ou de nocividade. Mas o sentimento de obstáculo, de perturbação ou de nocividade é um sentimento que é necessário chamar de normativo, já que ele comporta a referência, mesmo inconsciente, de uma função e de uma impulsão à plenitude do seu exercício (2007, p. 84).
\end{abstract}

Uma anomalia se torna patológica, portanto, quando ela é julgada negativamente, por um vivente individual. Voltaremos posteriormente a esse ponto, interessando-nos, por ora, insistir que se certas anomalias são negativamente apreciadas pelo vivente, que as vive como obstáculo, redução das suas possibilidades de existência, outras, porém, podem dar origem a formas inéditas de vida ao se tornarem normais graças ao seu caráter normativo:

\footnotetext{
Não há fato normal ou patológico em si. A anomalia ou a mutação não são nelas mesmas patológicas. Elas exprimem outras normas de vida possíveis. Se essas normas são inferiores às normas específicas anteriores quanto à estabilidade, à fecundidade, à variabilidade da vida, elas serão ditas patológicas. Se essas normas se revelam, eventualmente, no mesmo meio equivalentes, ou, em outros meios, superiores, elas serão ditas normais. Sua normalidade virá da sua normatividade (2007, p. 91).
}

Distinguir entre a anomalia e a patologia é conferir um novo estatuto àquilo que não se deixa reconduzir imediatamente às nossas categorias mais gerais de normalidade, e que, por isso, só pode ser designado negativamente sob as figuras do patológico, do perverso, do anormal, do doente, do monstro. Como vimos na primeira parte, era assim que a sociologia de Durkheim compreendia os fenômenos sociais que se desviavam da média social. No campo da medicina positivista, onde a concepção de normalidade hegemônica na teoria social desde o oitocentos deve ser procurada, encontra-se também a tendência de desqualificar o desvio individual em relação à normalidade identificada a uma certa medida. Diferentemente de 
Canguilhem, para quem a anomalia não é patológica enquanto não for experimentada pela vivente como possuindo um valor negativo num certo meio determinado, a esses pensadores que identificam o anômalo ao enfermo falta o que Macherey chama de "inteligência da anomalia":

\begin{abstract}
A inteligência da anomalia é precisamente este trabalho de um pensamento ligado à experiência e cioso antes de tudo de operar nos limites que essa lhe fixa concretamente, trabalho do pensamento que, para além das formas dadas da existência orgânica, disposição anatômica e análise quantitativa das funções ligadas à cada órgão ou grupo de órgãos, ultrapassa, dando um sentido aos valores negativos da existência, os índices de um poder de viver que não se deixa observar ou medir objetivamente, isto é, reconduzir a uma escala gradual de formas fazendo o objeto de uma abstrata comparação mecânica (2008, p. 73).
\end{abstract}

Essa inteligência da anomalia, porém, não é possível no quadro de uma concepção do biológico para a qual esse seria o domínio da estabilidade, da regularidade, da harmonia, como queria Comte, ou do determinismo fechado das leis, como preferia Claude Bernard. Para que o estatuto normativo da anomalia seja pensável, é preciso substituir a ideia de vida como um sistema fechado de leis $^{53}$ (1975 p. 156) pela ideia de ordem das propriedades:

Falando de uma ordem de propriedades, nós queremos designar uma organização de potências e uma hierarquia de funções cuja estabilidade é necessariamente precária, sendo a solução de um problema de equilíbrio, de compensação, de compromisso entre poderes diferentes e, então, concorrentes. Numa tal perspectiva, a irregularidade, a anomalia não são concebidas como acidentes afetando o indivíduo, mas como sua própria existência (1975, p. 159)

Com isso, Canguilhem quer afirmar que um indivíduo é a totalidade problemática de poderes ou exigências conflitantes, que constituem uma espécie de fundo pré-individual de toda forma de vida. Retomando, então, o problema posto alhures por Lecourt, a saber, de que maneira conciliar a aparente contradição em que incorre Canguilhem ao afirmar tanto a natureza absoluta da individualidade biológica quanto o seu caráter relativo, responder-se-ia que ela se localiza exatamente no conflito entre aquilo que no vivente aparece como sentido determinado e o que nele é da ordem da indeterminação. Em outras palavras, é a impossibilidade de que tais poderes encontrem uma satisfação plena que coloca em marcha o

\footnotetext{
53 Em Merleau-Ponty encontramos uma distinção similar, na medida em que, para o filósofo francês, o comportamento orgânico não pode ser compreendido segundo leis, mas a partir da ideia de norma: "de là vient que les structures inorganiques se laissent exprimer par une loi, au lieu que les structures organiques ne se comprennent que par une norme, par un certain type d'action transitive qui caractérise l'individu. (...) Cela signifie qu'il mesure lui-même l'action des choses sur lui et délimite lui-même son milieu par un processus circulaire qui est sans analogue dans le monde physique » (2002, p. 161).
} 
processo de individuação, induzindo-o a criar novos modos de síntese entre múltiplas séries concorrentes de exigências advindas da vida.

O papel ontogenético do conflito entre indeterminação e determinação no interior de cada singularidade vivente situa a filosofia canguilhemeana numa longa tradição, que poderíamos remontar a $\mathrm{Hegel}^{54}$ e a Freud, para a qual era preciso reconhecer no trabalho do negativo o movimento de aprofundamento que faz passar da natureza à cultura, anulando as dicotomias modernas entre necessidade e liberdade, fixidez e história ${ }^{55}$.

\section{$O$ vitalismo negativo de Canguilhem}

Desde o seu curso Les normes et le normal, Canguilhem reconhece à psicanálise o mérito de ter se aproximado mais do que todas as outras psicologias "de uma descrição exata do caráter axiológico da vida mental" (1942-1943, p. 119), isso porque Freud teria compreendido o papel central das noções de conflito e de polaridade na análise dos fenômenos psíquicos. Porém, se aí o conceito de pulsão é ainda pouco explorado, ele se tornará determinante nas últimas formulações de Canguilhem. O que nos autoriza a adicionar à bibliografia deste trabalho produções canguilhemeanas tão recentes é o fato de encontrarmos nelas formulações mais detalhadas daquilo que os textos e cursos anteriores apenas continham de maneira esboçada. Esse é o caso da discussão em torno da articulação entre o conceito freudiano de pulsão e a concepção canguilhemeana de normatividade e polaridade vital. Em um dos seus últimos textos, Canguilhem explicitamente se refere a tal articulação:

\footnotetext{
${ }^{54}$ A relação entre a filosofia de Hegel, em particular da sua Filosofia da Natureza, e a filosofia da vida de Canguilhem ainda não foi objeto de um estudo sistemático, não obstante as explícitas e variadas referências do segundo ao primeiro. Infelizmente, esta dissertação não poderá preencher tal lacuna, o que o autor comprometese a fazer em trabalhos futuros. Para tanto, uma pista importante parece ser a crítica que Canguilhem endereça a Kojève. Segundo o filósofo, "muitas vezes, Kojève é levado a defender o dualismo. Para ele, não haveria dialética natural, mas apenas humana (...). Eis porque Kojève é conduzido, muito alegremente, a deixar de fora do Sistema de Hegel toda a Filosofia da natureza, filosofia cosmológica e filosofia biológica. Após ter reconhecido que Hegel, na Enciclopédia - ou seja, dez anos após a Fenomenologia -, introduz a negatividade no próprio ser natural, Kojève decide: 'pessoalmente, partilho do ponto de vista da Fenomenologia e não admito a dialética do ser natural, do Sein' (p. 472, nota). Nós perguntaríamos então se Kojève não se dá conta de que, identificando o Homem, o Espírito e a História, separando radicalmente a história e a natureza, a Liberdade e a Identidade, ele escamoteia um problema tradicional em filosofia, aquele das relações, no homem, da natureza e da liberdade?" (1948, p. 290).

${ }^{55}$ Não é supérfluo lembrar, neste contexto, da maneira pela qual Canguilhem coloca em questão essas dicotomias: "Mas a vida? Não é ela evolução, variação de formas, invenção de comportamentos? Sua estrutura não é histórica tanto quanto histológica? A fisiologia penderia então em direção à história que não é, independentemente do que se faça, ciência da natureza" (2007, p. 157).
} 
Pode-se então perguntar por que uma teoria como aquela que Freud esboçou sob o nome de pulsão de morte (Para além do princípio do prazer, 1920) encontrou tantas resistências. Em Freud, essa ideia estava ligada a uma concepção energética da vida e do psiquismo. Ora, se é verdade que o vivente é um sistema em desequilíbrio incessantemente compensado por empréstimos do exterior, se é verdade que a vida está em tensão com o meio inerte, o que existe de estranho ou de contraditório na hipótese de uma pulsão de reduções das tensões a zero, de uma tendência à morte? (1989, p. 553).

Porém, é preciso que contextualizemos a remissão a Freud no percurso filosófico de Canguilhem. A citação acima se encontra no verbete Vie, publicado em 1989, na Encyclopaedia universalis, ou seja, no período em que o filósofo tomava contato com a nova linguagem introduzida na biologia pela teoria da informação. O que explica que Canguilhem afirme na continuação:

Talvez a teoria freudiana se torne o objeto de um novo exame em relação com as teses de Atlan: "na verdade, o único projeto reconhecível nos organismos vivos é a morte. Mas, por conta da complexidade inicial desses organismos, as perturbações capazes de desviá-los do estado de equilíbrio tem como consequência a aparição de uma complexidade ainda maior no próprio processo de retorno ao equilíbrio" ("Mort ou vif", in L'organisation biologique et la théorie de l'information, 1972) (1989, p. $553)$.

A relação que estabelece Canguilhem entre a última teoria pulsional freudiana e a teoria da informação de Atlan se esclarece, por um lado, a partir da maneira como esta última compreende a noção de erro, e, por outro, a partir da noção canguilhemeana de saúde, vinculada a experiências de excesso e de dissolução.

Com efeito, a saúde consiste para Canguilhem na capacidade normativa do vivente, isto é, no poder de criar novas formas de vida. Aqui, estamos muito longe de uma defesa do adaptacionismo como meta para a resolução do conflito entre o vivente e o seu meio. Como vimos na primeira parte, essa era a ideia que defendiam Durkheim e Comte, ambos se referindo a uma ordem ontológica de regulação transcendente aos indivíduos e à qual esses deveriam aderir para que a saúde social ou biológica pudesse ser conquistada. No entanto, adaptar-se é, para Canguilhem, adoecer, no sentido em que um vivente completamente adaptado às normas do meio vive sob a constante ameaça de uma destruição iminente acarretada pela transformação nas suas condições de existência. É certo, porém, que um organismo são é capaz de se adaptar (CANGUILHEM, 2007, p. 132), mas com a diferença de que ele, não estando fixado às normas de um meio específico, pode se ajustar normativamente (Ibidem, p. 94) a um outro meio qualquer (Ibidem, p. 87): "Estar são não é apenas ser normal numa situação dada, mas ser normativo, nessa situação e em outras possíveis” (Ibidem, p. 
130). A distinção entre dois tipos de adaptação, que Benmakhlouf designa como "adaptação específica" e "adaptação não-específica" (2000, p. 77), torna-se mais clara nas Nouvelles réflexions:

\begin{abstract}
Existe uma forma de adaptação que é especialização para uma tarefa dada num meio estável, mas que é ameaçada por todo acidente modificando esse meio. E existe uma outra forma de adaptação que é independência em relação as restrições de um meio estável e, por conseguinte, poder se superar as dificuldades de viver resultantes de uma alteração do meio (CANGUILHEM, 2007, p. 197).
\end{abstract}

A adaptação não específica responde ao "ideal normal humano que é adaptação possível e desejável a todas as circunstâncias" (Ibidem, p. 87). É bem esse ideal que define a saúde, para Canguilhem: “o que caracteriza a saúde é a possibilidade de ultrapassar a norma que define o normal presente, a possibilidade de tolerar infrações à norma habitual e de instaurar novas normas em situações novas" (Ibidem, p. 130). Em síntese, um vivente saudável é um vivente normativo, capaz de ultrapassar as exigências do presente. Nesse sentido, é interessante observar a rede lexical que envolve a noção canguilhemeana de saúde: abuso (Ibidem, p. 87), luxo (Ibidem, p. 132), insaciabilidade (Ibidem, p. 109), indeterminação (Ibidem, p. 129), deslimite (Ibidem, p. 134) ${ }^{56}$. Em suma, a saúde, em Canguilhem, é um excesso de normalidade, é uma normatividade: "o homem apenas se sente em boa saúde - que é a saúde - quando ele se sente mais que normal - isto é, adaptado ao meio e as suas exigências - mas normativo, capaz de seguir novas normas de vida" (Ibidem, p. 133). Por ser excesso, abuso, indeterminação da capacidade normativa, a saúde flerta com experiências de dissolução que podem apontar para doença e para a morte. É o próprio Canguilhem que afirma: "estar em boa saúde é poder cair doente e se levantar, é um luxo biológico" (Ibidem, p. 132). Ou, ainda: “(...) nós estimamos que o poder e a tendência de se tornar doente são uma característica essencial da fisiologia humana. Transpondo as palavras de Valéry, nós dissemos que o abuso possível da saúde faz parte da saúde” (Ibidem, p. 133). E, mais enfaticamente, conclui o filósofo:

\footnotetext{
${ }^{56}$ Os termos utilizados por Canguilhem evocam nitidamente Bataille. Referência que dificilmente encontraria alguma justificação biográfica, posto que, salvo engano, Canguilhem nunca se mostrou um leitor atento do Colégio de Sociologia, em particular do autor de L'erotisme. Sobre o interesse do filósofo francês por Bataille, uma anedota contada por Camille Limoges e registrada por Xavier Roth é sem dúvida bastante ilustrativa: "Lors d'une séance, une des étudiantes du séminaire eut le malheur d'apporter avec elle un livre de Bataille, très en vogue à l'époque. Bien mal lui en pris. Lorsque Canguilhem s'en aperçut, il stoppa net son exposé, et piqua une colère vive : 'comment peut-on perdre son temps avec ce genre de littérature quand on ne connaît pas les trois Critiques sur le bout de doigts ! "' (2010, p. 66-67). Contudo, do ponto de vista teórico, a distância entre os dois pensadores parece menor se admitirmos que ambos procuram recuperar a dignidade filosófica das experiências de excesso e transgressão na crítica ao sujeito moderno.
} 
Ora, como nos pareceu reconhecer na saúde um poder normativo de colocar em questão normas fisiológicas usuais pela procura do debate entre o vivente e o meio procura que implica a aceitação normal do risco da doença -, do mesmo modo nos parece que a norma em matéria de psiquismo humano é a reivindicação e o uso da liberdade como poder de revisão e de instituição de normas, reivindicação que implica normalmente o risco da loucura (1975, p. 168).

Nesse sentido, não seria ousado afirmar que a normatividade vital não se regula pelo cálculo utilitarista do prazer, na medida em que ela procura algo para além da satisfação de exigências instintuais de autoconservação. É por isso que, para Canguilhem, "uma boa definição de saúde" (Ibidem, p. 109), válida para todos os viventes, acha-se numa afirmação central de Porak: "A melhor definição de homem seria, e acredito, um ser insaciável, isto é, que ultrapassa sempre suas necessidades" (apud CANGUILHEM, 2007, p. 109, grifos nossos). Em outras palavras, a noção canguilhemeana de saúde revela a irredutibilidade do vital a um tipo de explicação que pensaria as ações de um organismo como efeitos determinados por impulsos instintivos, por necessidades naturais, como se a natureza funcionasse como um sistema causal fechado, semelhante ao que encontramos nas máquinas. Ora, tal forma de explicar os fenômenos vitais é precisamente aquela que vimos em Claude Bernard, na medida em que, para ele, qualquer criação biológica deve necessariamente se submeter à determinação imposta por um sistema invariável de leis, diante do qual o indeterminado e o irregular não possuem consistência própria.

A distinção entre saúde e autoconservação aproxima Canguilhem do conceito freudiano de pulsão de morte, na medida em que também ele coloca em operação, segundo Safatle, uma noção não positiva de natureza, compreendida como aquilo que "não se deixa pensar a partir de figuras do ciclo vital ou de alguma forma de funcionalismo ordenador, mas que se manifesta necessariamente como resistência à integração a todo e qualquer princípio de determinação positiva" (2006, p. 167).

A resistência da natureza a qualquer princípio geral de ordenação ou de unificação decorre do caráter mesmo do pulsional, definido por Freud em Para além do princípio do prazer como uma: “(...) força impelente [Drang] interna ao organismo vivo que visa a restabelecer um estado anterior que o ser vivo precisou abandonar devido à influência de forças perturbadoras externas" (FREUD, 2006, p. 160). Isso explicaria certos fenômenos da vida psíquica ${ }^{57}$ aparentemente ininteligíveis a partir do quadro de compreensão fornecido pelo

\footnotetext{
${ }^{57}$ Além da compulsão à repetição, que mencionaremos a seguir, foram também fundamentais para Freud propor a existência de uma pulsão de morte os problemas encontrados pela clínica psicanalítica ao se confrontar com fenômenos psíquicos como a ambivalência dos desejos, a agressividade, o sadismo e o masoquismo.
} 
princípio do prazer. Com efeito, os fenômenos de repetição verificados na clínica psicanalítica parecem escapar a um regime de funcionamento da economia mental caracterizada pela manutenção da constância da quantidade de excitação no aparelho psíquico resultante da satisfação libidinal, pois eles, ao contrário, aumentam esse quantum, produzindo inibições, sintomas e angústia. Assim, torna-se necessário supor a existência de uma tendência própria do psiquismo, mais originária que a procura do prazer, que seria eminentemente de caráter regressivo, pois sua meta consistiria justamente em dissolver os agregados, diluir as unidades, fazendo-as retornarem a um nível zero de tensão próprio do inorgânico.

Dissolver unidades significa, para Freud, quebrar as sínteses entre libido e representações produzidas pelo ego sobre os processos primários. $\mathrm{Na}$ medida em que os fenômenos de repetição revelam a incapacidade do ego de ligar o grande afluxo de energia psíquica oriunda, por exemplo, de um trauma, eles devem ser compreendidos, segundo Safatle, "como movimento de retorno em direção à aniquilação de um indivíduo determinado, como o que orienta a sua conduta a partir da conservação de si graças ao cálculo do prazer, à simbolização de experiências traumáticas que bloqueiam disposições sintéticas da consciência e à efetivação de um princípio de individuação" (2006, p. 164).

Assim, pulsão de morte significa aqui a tendência imanente a todo e qualquer vivente de dissolver as unidades estáveis produzidas por Eros. No interior de cada individualidade orgânica encontra-se esse conflito entre Eros e Tânatos, entre pulsões de vida e pulsões de morte, que Freud assim resume: “A meta de Eros é estabelecer unidades cada vez maiores, portanto conservar; é a ligação. A meta da outra pulsão, pelo contrário, é quebrar as relações, portanto destruir as coisas” (FREUD apud LAPLANCHE; PONTALIS, 1998, p.413).

Nesse sentido, a noção de normatividade vital partilha com a pulsão de morte freudiana do mesmo papel de quebra das sínteses biológicas. Uma individualidade saudável só pode ser, então, uma individualidade capaz de colocar em questão formas de vida, normas de comportamento, que garantem aos organismos a sua identidade a si. Essa ideia de que organizações biológicas se constituem em conflito com um fundo permanente de desorganização não é estranha à maneira como Atlan interpreta a biologia contemporânea à luz da teoria da informação. Também para ele, é preciso reconhecer o trabalho do negativo em execução na vida: 
chamar a vida e a morte, somente podem existir na medida em que não se tratam de colaboração, mas sempre de oposição radical e de negação (1986, p. 58, grifos nossos).

Atlan se refere nessa passagem aos processos de organização a partir de ruídos ou de erros produzidos no interior de um sistema biológico. O que a teoria da informação chama de erro é um engano possível na decodificação das mensagens transmitidas entre estruturas biológicas. Canguilhem nos fornece um exemplo:

\begin{abstract}
Já que as enzimas são os mediadores pelos quais os genes dirigem as sínteses intracelulares de proteínas, já que a informação necessária para essa função de direção e de vigilância está inscrita nas moléculas de ácido desoxirribonucleico no nível do cromossomo, essa informação deve ser transmitida como uma mensagem do núcleo ao citoplasma, onde deve ser interpretada a fim de que seja reproduzida, recopiada, a sequência de ácidos aminados constitutiva da proteína a sintetizar. Mas, não importa qual seja o modo, não existe interpretação que não implique um engano possível. A substituição de um ácido aminado por um outro cria a desordem por ininteligência do comando (2007, p. 208).
\end{abstract}

Não foram poucos os que viram realizadas nessas palavras as expectativas de racionalização dos fenômenos vitais a partir de uma lógica imanente à estrutura genética dos organismos, como se finalmente a decodificação das séries de ácidos aminados que compõem o DNA de uma célula fornecesse uma espécie de gabarito a partir do qual se poderia julgar sobre a verdade ou o erro da vida. Contudo, com o artigo Un nouveau concept en pathologie: l'erreur, Canguilhem pretende justamente frustrar essa pretensão cientificista de fundar as normas biológicas nas moléculas de ácido desoxirribonucleico. Que possa ocorrer um erro possível na transmissão de informações, isso não diz nada sobre o valor vital desse erro, seu caráter patológico ou são. Acerca de tal valor, cabe ainda ao organismo decidir: "se ela [a noção de erro] consiste, de início, em uma confusão de fórmula, em um falso tomado por verdadeiro, ela é reconhecida como tal na conclusão de uma busca suscitada pela dificuldade de viver, ou pela dor, ou pela morte de alguém" (Ibidem, p. 211).

Com efeito, é preciso levar em conta a existência de anomalias genéticas que, assim como as anomalias morfológicas mencionadas acima, podem permanecer ignoradas por seus portadores, na medida em que elas não foram ativadas pelo encontro aleatório com certas características do meio vital. Além disso, há erros de decodificação molecular que "conferem, em alguns contextos ecológicos, uma certa superioridade àqueles que é preciso então chamar de seus beneficiários" (Ibidem, p. 213). Assim, Canguilhem é levado a concluir que "(...) os erros da organização não contradizem a sabedoria dos organismos, ou seja, os sucessos de organização" (Ibidem, p. 212). 
Nesse ponto, Canguilhem ecoa a noção de erro de Atlan. Para este, a ocorrência de erros é necessária para a redução do nível de redundância nas organizações biológicas, abrindo espaço para a configuração de novas organizações. Assim, contra Bichat, para quem "a vida é o conjunto das funções que resistem à morte", Atlan pode afirmar que "a vida é o conjunto das funções capazes de utilizar a morte" (ATLAN, 1986, p. 278). Com efeito, só há vida e organização, lá onde há morte e desorganização, pois "a organização consiste precisamente numa sequencia de desorganizações retomadas" (Ibidem, p. 57). Como afirma Atlan:

Tudo isto conduz à ideia de que a organização dos sistemas vivos não é uma organização estática, nem mesmo um processo que se oporia às forças de desorganização, mas bem um processo de desorganização permanente seguida de reorganização, como aparição de propriedades novas se a desorganização pode ser suportada e não matar o sistema. Dito de outra forma, a morte do sistema faz parte da vida, não somente sob a forma de uma potencialidade dialética, mas como uma parte intrínseca de seu funcionamento e da sua evolução: sem perturbações ao acaso, sem desorganização, não há novas reorganizações adaptativas; sem processos de morte controlada, não há vida (Ibidem, p. 280).

Em linhas gerais, desde a perspectiva da teoria da informação, as organizações viventes são sistemas cujo equilíbrio instável é mantido por um processo constante de troca de informações com o meio ${ }^{58}$. Durante essa transmissão, fatores aleatórios podem produzir ruídos que afetam a quantidade de informação trocada, colocando ou não em risco o organismo. Seja, por exemplo, um sistema $\mathrm{S}$ muito simplificado ${ }^{59}$, composto por uma via de transmissão de informação da subestrutura A à B. A partir da posição do observador que

\footnotetext{
${ }^{58}$ Para Atlan o meio não é uma posição determinada, mas varia de acordo com o ponto de vista que se assume entre os diferentes níveis de organização. Assim, do ponto de vista do órgão que observa as vias de comunicação intracelulares, o meio se identifica ao meio celular no interior do qual se situam estas subestruturas.

${ }^{59} \mathrm{O}$ próprio Atlan reconhece que este exemplo somente é válido se se considera este $\mathrm{S}$ como um sistema artificialmente isolado, no interior de uma organização complexa. "Com efeito - afirma o biofísico - em um sistema rígido e relativamente simples onde as vias de comunicação não podem ser definidas senão de uma única forma, a diminuição da transmissão numa via sob efeito de fatores de ruído só pode ser concebida como um processo de destruição do sistema. Para poder contar a ambiguidade com o seu sinal + , nós devemos supor que o sistema pode se reorganizar ele mesmo de tal modo que, ainda que 1 e 2 se tornem menos interdependentes (e mesmo independentes quando a ambiguidade $\mathrm{H}(\mathrm{y} 2 / \mathrm{y} 1)$ é máxima e igual a $\mathrm{H}(\mathrm{y} 2))$, elas continuam, porém, a funcionar de uma nova força no interior do sistema; isto quer dizer que existe ainda algumas outras relações indiretas, por intermédio de outras subestruturas e de outras vias, ainda que a via considerada de 1 a 2 se torne menos, ou mesmo não totalmente, eficaz" (ATLAN, 1972, p. 261).

É por essa razão que, seguindo os termos do cibernético von Neumann, Atlan considera que a noção ambiguidade-autonomia exprime uma propriedade que só pode ser observada em "sistemas extremamente altamente complicados" (systèmes extrêmement hautement compliqués), devido ao grande número de subsistemas e de vias de comunicação que os compõem, e de sua grande redundância (cf., ATLAN, 1972, p. 261 $262 ; 1979$, p. 48-49).
} 
avalia a quantidade de informação total ${ }^{60}$ contida neste sistema $\mathrm{S}$, primeiramente considerase a via $\mathrm{AB}$ livre da incidência de qualquer ambiguidade ou equivocação ${ }^{61}$. Nesse caso, como não há ruído, a pressão ${ }^{62}$ entre as partes que compõe o sistema é máxima e a subestrutura B é uma cópia exata de $\mathrm{A}$, sendo a quantidade de informação total do conjunto $\mathrm{A}$ e $\mathrm{B}$ igual àquela de A. Num segundo momento, observa-se a ocorrência de um certo número de erros nesta via, de tal modo que a ambiguidade torna-se igual à quantidade de informação de A. Assim, $a$ pressão entre as partes do sistema $S$ é inexistente, pois não há mais transmissão de informação entre elas. A subestrutura B, então, é completamente independente de A, de forma que a quantidade de informação total do conjunto $\mathrm{A}$ e $\mathrm{B}$ é igual à somatória da quantidade de informação das suas subestruturas, isto é, igual àquela de A mais a de B.

Ambos os momentos, o de completa inexistência de pressão e o de pressão máxima entre as subestruturas, correspondem à ausência total de organização do sistema: no primeiro caso, tem-se uma mesma subestrutura repetida $\mathrm{N}$ vezes e, no segundo, há somente uma justaposição de subsistemas completamente independentes entre $\mathrm{si}^{63}$. Isso leva Atlan a

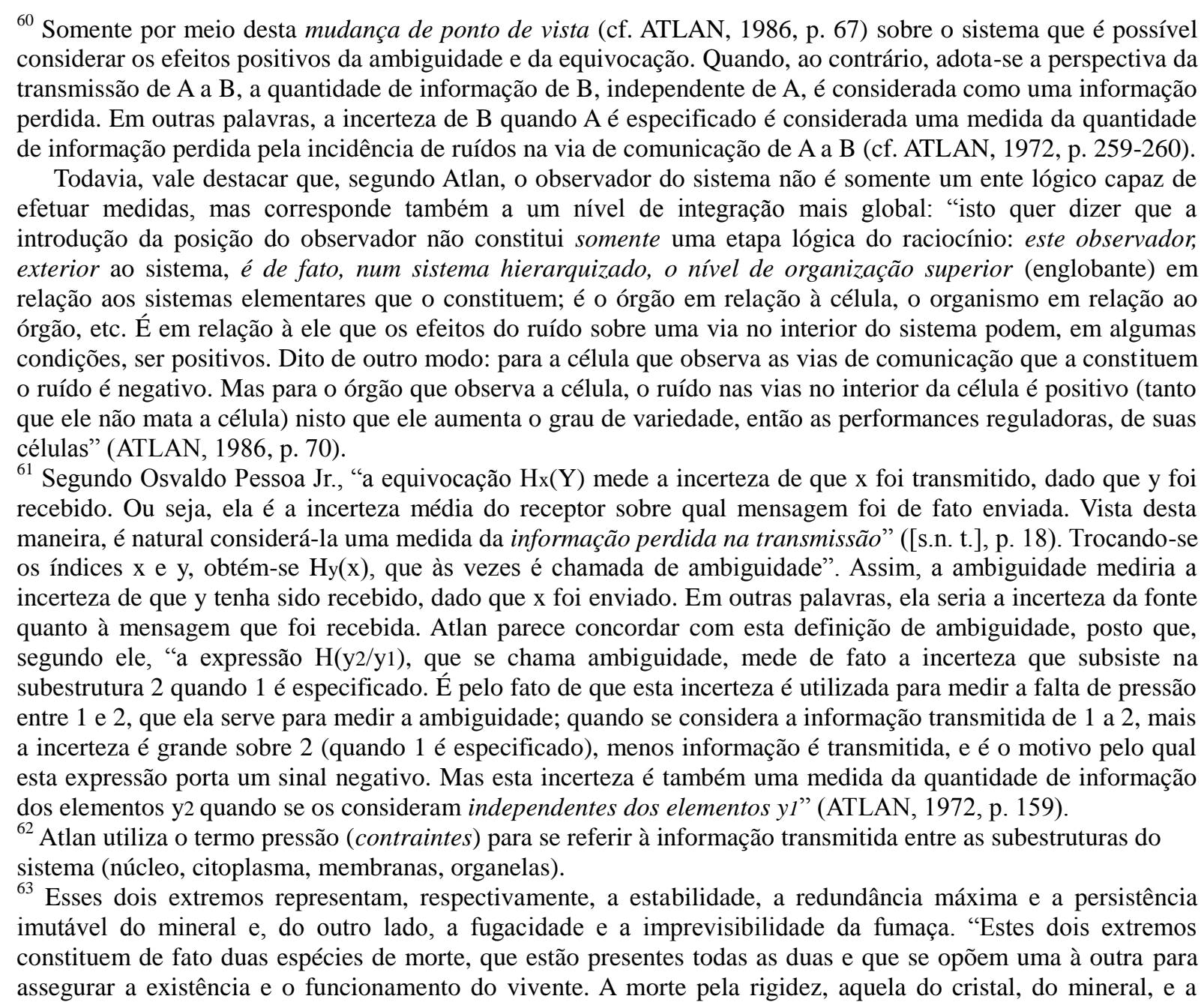


concluir que a organização consiste em um estado intermediário, no qual a pressão entre as partes não é máxima, posto que há transmissão entre as estruturas, mas com alguma ambigüidade ou equivocação. Assim, observa Atlan, "do ponto de vista da quantidade de informação deste sistema, um optimum é realizado quando existe uma transmissão de informação não nula entre A e B, mas com uma certa quantidade de erros, produzindo uma ambigüidade ela também não nula" (ATLAN, 1986, p. 47).

Se não houvesse erro na transmissão da informação, e nem a ambiguidade dele decorrente, então os sistemas orgânicos seriam absolutamente redundantes e o particular não existiria; por outro lado, se houvesse apenas erro, então os organismos se dissolveriam. Por isso, para que seja possível falar em organismos, é preciso conceber um grau mínimo de redundância $\left(\mathrm{R}_{0}\right)$, a partir do qual o decréscimo de pressão possa se efetuar por ação do ruído, aumentando a complexidade da estrutura. Esse aumento de complexidade confere ao vivente, do nível mais inferior ao mais englobante, um acréscimo de informação "que ele utiliza eventualmente para uma melhor adaptação a condições novas” (Ibidem, p. 82).

O erro é um acontecimento necessário para a vida do organismo, sem o qual esta não seria nada mais que uma forma absolutamente estável, plenamente aderida as suas condições de existência. Daí porque, para Canguilhem, errar é uma maneira do vivente se informar, isto é, advir uma nova forma de vida que poderá não mais se realizar sobre o mesmo meio. $\mathrm{O}$ vivente então é impelido a mudar de meio, a produzir novas normas de existência, enfim, a errar no sentido de se transformar para realizar suas expectativas vitais.

O que é assim posto em questão é a ideia de que a vida seria uma natureza substancial, fonte positiva das manifestações individuais que seriam os organismos. Como insiste Le Blanc, a perspectiva da normatividade vital exige que se leve em consideração o sentido negativo dos valores vitais, o que significa dizer que: "a multiplicidade das formas que assume a vida supõe uma negatividade interna à vida que implica que a vida nunca está em fase com ela mesma, que ela está sempre no transbordamento em relação às normas anteriores” (p. 58, grifos nossos). A noção de erro aparece para definir essa negatividade interna à vida, que coloca em risco as totalidades orgânicas existentes devido à dissolução da sua norma interna de unificação. É por isso que, segundo Badiou, não existe em Canguilhem um conceito positivo de sujeito ao qual pudéssemos fazer corresponder o organismo (1993, p. 296). Como tentamos afirmar por ocasião da nossa análise sobre o estatuto das vida, a outra a renovação da vida" (ATLAN, 1986, p. 281). 
individualidades biológicas na filosofia canguilhemeana, quando o teórico fala sobre o indivíduo, ele se refere menos a uma unidade pré-existente fundamento do sentido e da experiência doente, e mais a um campo conflitual de valores ou àquilo que Badiou designa como uma "egologia negativa" (Ibidem, p. 300), que "se poderia transcrever num decalque da famosa definição da vida por Bichat, que Canguilhem cita muito frequentemente. Dir-se-ia então: 'o sujeito é o conjunto das funções que resistem à objetivação"' (Ibidem, p. 300).

Estabelecidos os conceitos fundamentais da filosofia canguilhemeana da vida entre o final dos anos 1930 e início de 1950, o filosófo voltará, em seguida, a se concentrar sobre a temática sociológica, que havia perdido espaço no pensamento canguilhemeano em detrimento da reflexão sobre as ciências médicas e biológicas. As Nouvelles réflexions, publicadas em 1966, constituem o momento culminante dessa retomada do social como objeto privilegiado de inquérito filosófico. Nesse sentido, não é supérfluo reiterarmos que, como pretendemos sustentar até aqui, em particular na primeira parte desta pesquisa, essas novas reflexões não marcam o ponto de estréia de Canguilhem no campo do pensamento social. Ao contrário, se elaboram em estreita continuidade com alguns dos problemas que o filosófo já explicitara nas sua crítica à sociologia de Durkheim e de Comte. Mas como não se poderia falar propriamente em retorno para descrever o movimento de um pensamento que sempre desconfiou da ideia de recuperação de um estado normativo anterior ou mais originário, então é o caso de investigarmos, o que pretendemos fazer nesta próxima parte, quais são as consequências da filosofia normativa da vida para a reflexão sobre o social que Canguilhem conduz a partir de meados dos anos 1950 até as Nouvelles réflexions. 


\section{Parte III - Normatividade social: vida humana e racionalização}

$\mathrm{Na}$ breve apresentação que escreve para as suas Nouvelles réflexions, Canguilhem compara, "vingt ans après...", os dois cursos sobre Les normes et le normal, o de 1942-1943 e o de 1962-1963, com o Essai, concluindo que eles "transbordavam em extensão" o tema de filosofia médica tratado na tese de doutoramento.

Desde o nosso primeiro capítulo, tentamos deixar claro que este transbordamento era resultado de uma investigação precoce sobre a constituição dos conceitos de normal $e$ patológico como categorias organizadoras da racionalidade científica no âmbito da teoria social. Com efeito, já na década de 1940, Canguilhem lançava perguntas que só viriam a público com as Nouvelles réflexions: qual a relação entre as diferentes normas sociais?, como distinguir entre a saúde e a doença sociais?, o que difere um organismo de uma sociedade?. Mais do que isso: o curso de 1942-1943 é como que a imagem invertida do livro que, posteriormente, em 1966, vai se chamar Le normal et le pathologique. Enquanto que neste o Essai é seguido das Nouvelles réflexions, naquele os problemas relacionados às normas sociais precedem as análises sobre o conceito de norma, normal e patologia nas ciências da vida.

Em outras palavras, como tentamos defender nesta dissertação, tudo se passa como se a filosofia da vida elaborada no Essai fosse consequência da necessidade de fundar sobre novas bases a crítica à racionalidade médico-científica que se incorporou às ciências humanas a partir das categorias de normal e de patológico. Revendo seus cursos, o filósofo conclui que

\footnotetext{
o sentido dos conceitos de norma e de normal nas ciências humanas, em sociologia, em etnologia, em economia, leva a pesquisas que tendem, finalmente, quer se trate dos tipos sociais, dos critérios de inadaptação ao grupo, das necessidades e dos comportamentos de consumo, dos sistemas de preferência, à questão das relações entre generalidade e normalidade (2007, p. 173).
}

Relação entre generalidade e normalidade que Canguilhem primeiro diagnostica na polêmica em torno do estatuto de cientificidade das categorias de saúde e patologia sociais, em Durkheim. Daí porque a escolhemos como o ponto de partida da nossa dissertação, o que nos levou a seguir os passos de Canguilhem até a genealogia desta polêmica na medicina de Comte e Claude Bernard. Nessas, descobrimos em funcionamento um modelo de racionalidade que opera pela redução da heterogeneidade do patológico à homogeneidade do 
normal, da qualidade à quantidade, do diverso biológico à identidade de uma vida que se desdobra sempre idêntica a si na multiplicidade das suas criações.

Contudo, parece que a esta dissertação falta ainda um último capítulo: após mostrarmos como um conceito renovado de vida se constituía como elemento fundamental da crítica ao pensamento da identidade e da racionalidade médico-biológica característica da fisiologia de Comte e Claude Bernard, não seria o caso, então, de voltarmos ao problema da normalidade e da patologias sociais, como o próprio Canguilhem faz ao escrever as suas Nouvelles réflexions?

De fato, é inegável que dos três artigos que constituem as Nouvelles réflexions, dois deles se dedicam explicitamente a refletir sobre a relação entre as normas sociais e as normas orgânicas: Du social au vital e Sur les normes organiques chez l'homme. Porém, cabe aqui citar a ressalva do seu autor quanto aos objetivos destas novas reflexões, especialmente para justificar a retomada, a partir de lições precedentes, do interesse pelas ciências humanas:

Se eu emprestei, no início, alguns elementos de análise das lições nas quais eu examinei, à minha maneira, alguns aspectos desta questão [da relação entre norma e generalidade, tal como ela aparece no âmbito das ciências humanas], é unicamente para esclarecer, pela confrontação das normas sociais e das normas vitais, a significação específica destas últimas. É em vista do organismo que eu me permito algumas incursões na sociedade (2007, p. 173).

As Nouvelles réflexions, realmente, não pretendem constituir uma teoria renovada do social a partir da filosofia canguilhemeana da vida. Isso, porém, não nos impede de extrairmos algumas consequências do vitalismo negativo de Canguilhem para a crítica de um certo modelo de inteligibilidade do social. Veremos que esse modelo é aquele que identifica o social ao orgânico concebendo o primeiro como uma totalidade funcional mantida por um princípio interno de regulação. As sociedades seriam, portanto, portadoras dos fins supremos segundo os quais se orientaram os seus diversos componentes. O que retorna, assim, ao campo da reflexão canguilhemeana é a ontologia social de Durkheim, para qual a sociedade deve ser entendida como possuindo os mesmos mecanismos regulativos que existem nos organismos, o que já estava anunciado na leitura que Canguilhem faz do sociólogo no seu curso de 1947: “a noção [de sociedade] é aquela de um ser transcendente ao indivíduo cuja realidade seja capaz de portar o valor supremo, aquele que serve para regular e reger definitivamente toda a atividade do indivíduo" (CANGUILHEM, 1947, p. 1, negritos nossos). Mas não é somente Durkheim que assimila a sociedade ao organismo. Outro autor privilegiado pela reflexão canguilhemeana procede exatamente da mesma maneira: trata-se de Comte. Na interpretação 
de Canguilhem, a política positiva é concebida por Comte como "uma função geral de regulação social" (1972, p. 712). Dizer que a sociedade possui valores que regulam e regem toda a atividade individual é afirmar que ela cria suas próprias normas de funcionamento, o que, como afirmamos na segunda parte deste trabalho, é precisamente o que define o orgânico para Canguilhem.

\section{Regulação biológica e regulação social}

Fundamentalmente, para Canguilhem, é a partir da ideia de regulação ${ }^{64}$ que se fundamenta a distinção entre organismo e sociedade.

$\mathrm{Na}$ sua acepção geral, regulação define "o ajustamento, conforme a alguma regra ou norma, de uma pluralidade de movimentos ou de atos e de seus efeitos ou produtos que sua diversidade ou sucessão tornam, inicialmente, estranhos uns aos outros" (CANGUILHEM, 1955, p. 1). Porém, no campo das ciências da vida, é sem dúvida a Claude Bernard que se deve a consolidação do sentido propriamente biológico desse conceito. Para um organismo, regulação passa então a significar um “(...) sistema de mecanismos de correção e de compensação de desvios ou danos que ele sofre relativamente ao mundo no qual vive, relativamente a seu meio, meio a respeito do qual a existência desses mecanismos de regulação lhe permite levar uma existência relativamente independente" (Ibidem, p. 68).

À ideia de regulação está indissociavelmente ligada a noção de norma ou de regra a que obedecem os mecanismos de correção e compensação visando a manutenção constante das relações entre elementos instáveis. Porém, como se estabelece a relação entre aquela norma e estes mecanismos no caso do organismo? Algo a difere da maneira como a regulação se exerce nas sociedades? Chegamos, assim, ao núcleo dos problemas fundamentais da reflexão canguilhemeana sobre o social.

No organismo, a presença da norma é imediata ao sistema de regulação, de forma que "as regras de ajustamento das partes entre elas são imanentes, presentes sem ser representadas, eficientes sem deliberação nem cálculo" (CANGUILHEM, 2007, p. 186). Para Canguilhem, tudo se passa como se os mecanismos de regulação obedecessem a normas que lhes forneceriam, sem ambiguidades ou ruídos, determinações precisas a respeito das condições ótimas da vida do organismo. Em passagens fundamentais da conferência Le

\footnotetext{
${ }^{64}$ Lavoisier é quem importa para a fisiologia animal o termo "regulador", empregado amplamente na relojoaria, na política e na mecânica, do qual se originará, no século XIX, o conceito de regulação, cuja disseminação pela biologia e pela teoria social se dará ao longo do século XX.
} 
problème des régulations dans l'organisme et dans la société, o filósofo chega mesmo a afimar que "um organismo é um modo de ser totalmente excepcional pelo fato de que entre sua existência e seu ideal, entre sua existência ou sua regra e a sua norma, não há diferença propriamente falando" (CANGUILHEM, 1955, p. 67), ou, ainda:

\begin{abstract}
A partir do momento que um organismo existe, a partir do momento que ele vive, é que ele é possível, isto é, que ele responde a um ideal de organismo; a norma ou a regra de sua existência é dada na sua própria existência; de modo que se tratando de um organismo vivente, e para tomar o exemplo mais banal, tratando-se do organismo humano, a norma que é preciso restaurar quando este organismo está lesado ou doente, não se presta à menor ambiguidade (Ibidem, p. 67).
\end{abstract}

A imediticidade da norma ao organismo faz da saúde um ideal não problemático para a terapêutica que o visa como horizonte de restauração do organismo enfermo:

\begin{abstract}
Sabe-se muito bem qual é o ideal de um organismo doente; o ideal de um organismo doente é um organismo são da mesma espécie. Quer dizer então que mesmo que não se saiba exatamente em que consiste a desordem orgânica, ainda que o médico discuta sobre a natureza do mal, que se discuta sobre a composição e a administração dos remédios, ninguém discute sobre o efeito esperado desses remédios; o efeito esperado desses remédios é a restauração do organismo no seu estado de organismo são; em suma, o ideal do organismo é aqui claro para todo o mundo, é o próprio organismo (Ibidem, p. 67).
\end{abstract}

Afirmações como essas, que insistem em descrever a terapêutica como um processo de restauração de uma norma já presente na existência do próprio organismo, não deixam de causar alguma estranheza confrontadas com o conceito canguilhemeano de vida enquanto atividade normativa. Afinal de contas, era o próprio Canguilhem quem defendia a impossibilidade de se pensar a cura como retorno a um estado ou a uma norma anterior ou que opunha a norma à realidade ou ao existente. Não seria justamente negar essa oposição concluir que a norma é um ideal ao qual o vivente deve se submeter, ecoando praticamente aquilo que Durkheim afirmava sobre os fatos sociais normais? A norma não voltaria a ser pensada como um pré-existente que forneceria às múltiplas manifestações da vida sua forma específica? Falar em ideal não seria significaria reincorporar ao discurso sobre o vital um conceito oriundo daquela filosofia realista, que Canguilhem denunciara na ontologia social durkheimeana quando essa pretendia explicar a normalidade a partir da realização de um ideal de perfeição que portava o ser social?

Ora, o que sabemos a respeito da filosofia canguilhemeana da vida é suficiente para respondermos negativamente a todas essas perguntas. De fato, quando expúnhamos a concepção de Canguilhem de adaptação não específica, afirmávamos que, para o filósofo, 
ideal significa "a adaptação possível e desejável a todas as circunstâncias" (2007, p. 87). Nessa afirmação, encontrávamos uma formulação maior para o conceito canguilhemeano de saúde como capacidade do vivente realizar experiências produtivas de indeterminação, criando novas normas de existência para além das exigências de auto-conservação. Assim, nada seria mais estranho a esse pensamento do que afirmar algum tipo de teleologia do vital, posto que um organismo que obedece a fins previamente estabelecidos, cuja ação não cria normas inéditas de comportamento, só pode aparecer para Canguilhem como um vivente doente, cuja vida se restringiu aos limites da realidade.

Portanto, se Canguilhem, em Le problème des régulations dans l'organisme et dans la société, chega a defender que não há diferença entre o ideal de um organismo e a sua própria existência, que o ideal do organismo doente é um organismo saudável da mesma espécie, que “(...) a finalidade do organismo é interior ao organismo e, por conseguinte, esse ideal que é necessário restaurar é próprio organismo" (1955, p. 67), não é por uma retomada tardia e abrupta de alguma ontologia da qual se poderia extrair uma concepção substancialista de vida. É preciso ler essas passagens a partir do que expusemos sobre a filosofia canguilhemeana na segunda parte desta dissertação. Nesse caso, os conceitos de ideal e finalidade orgânicas, sob a pena de Canguilhem, transformam-se em categorias dinâmicas, cuja existência resulta daquela capacidade normativa que define o vital. Por isso, elas são desprovidas de qualquer tipo de conteúdo normativo pré-fixado, existente a priori na essência de um organismo. Daí porque não se pode compreender o sentido do termo restaurar, empregado por Canguilhem, como significando retornar a uma norma anterior, recuperar uma normalidade determinada da qual o organismo se afastou pela doença. Sendo a saúde o poder de ultrapassar o normal presente, a cura não pode ser o retorno a um normal passado, já desvalorizado pela doença, mas a criação de um novo normal. Quanto a isso, Canguilhem é claro ao afirmar:

\footnotetext{
Porque a saúde não é uma constante de satisfação, mas o a priori do poder de dominar situações perigosas, esse poder é usado para dominar perigos sucessivos. A saúde após a cura não é a saúde anterior. A consciência lúcida do fato de curar não ser retornar, ajuda o paciente em seu busca de um estado de menor renúncia possível, liberando-o da fixação ao estado anterior (2005, p. 70).
}

Portanto, toda cura implica sempre na criação de uma nova finalidade, na posição de novos fins segundo os quais o organismo, em sua totalidade, vai se regular. Por isso que, para Canguilhem, afirmar a existência de uma finalidade interna aos organismos, pela qual os mecanismos regulatórios trabalhariam a fim de manter a constância e o equilíbrio entre as partes que compõem o vivente, é afirmar que "o próprio de um organismo é viver como um 
todo e de não poder viver senão como um todo" (Ibidem, p. 68). Os sistemas de regulação presentes no desenvolvimento embriológico e nos processos de regeneração mostram claramente, segundo Canguilhem, que não obstante certos danos causados por agentes externos, a forma específica se acha constantemente preservada e mantida. Nas palavras do filósofo, tais sistemas “(...) mostram bem que há uma espécie de dominação da forma sobre a matéria, uma espécie de comando sobre as partes" (Ibidem, p. 69).

Contudo, à diferença dos viventes, as normas sociais de ajustamento das partes são transcendentes à totalidade ajustada, razão pela qual a aprendizagem, a aplicação e o controle dessas regras se tornam problemas significativos para aquele que deve cuidar da regulação social: o político.

É inegável que Canguilhem também concebe algum grau de coesão ou de copresença dos indivíduos e de instituições na sociedade, porém é importante ressaltar mais uma vez que esta totalidade não é obtida pela subordinação a uma norma interna. Se há normas sociais, estas não podem ser pensadas como revelando uma finalidade intrínseca à sociedade senão à custa da sua hipóstase na forma de um ente transcendente como na "ontologia social de Durkheim".

O organismo, portanto, não é a imagem da sociedade. Se se quer designar o modo particular de agenciamento dos indivíduos no interior de uma totalidade social, é melhor, observa Canguilhem, utilizar o termo organização. Com efeito,

\footnotetext{
O fato de que uma sociedade é organizada - e não há sociedade sem um mínimo de organização - não quer dizer que ela é orgânica; eu diria mesmo que a organização no nível da sociedade é mais da ordem do agenciamento do que da ordem da organização orgânica, pois o que faz o organismo é precisamente a sua finalidade, sob forma de totalidade, lhe é presente e é presente a todas as partes. Eu me desculpo, eu talvez vou escandalizar vocês, mas uma sociedade não tem finalidade própria; uma sociedade é um meio; uma sociedade é mais da ordem da máquina ou do instrumento do que do organismo (Ibidem, p. 71).
}

Sabemos que, para Canguilhem, uma máquina se define como um conjunto atomizados de mecanismos que mantém entre si uma certa regra fixa de relação, o que garante o funcionamento do todo. Porém, aí onde a sociedade parece se distanciar completamente do organismo, a saber: na sua identificação a uma máquina, o filósofo sugere um certo tipo de vinculação entre ambos. De fato, como vimos no capítulo anterior, Canguilhem pretende apagar a oposição rígida entre mecanismo e finalismo a partir da constatação de que uma máquina não é capaz de explicar, por si mesma, por que e como ocorreu sua construção, por que seus elementos obedecem a uma determinada estrutura relacional dentre outras possíveis, 
razão pela qual, enfim, ela executa um movimento específico e não outro. Assim, "Vê-se mal, por conseguinte, onde se encontra a oposição entre o mecanismo e a finalidade. Ninguém duvida que seja preciso um mecanismo para assegurar o sucesso de uma finalidade; e, inversamente, todo mecanismo deve ter um sentido, pois o sentido não depende de um mecanismo fortuito e qualquer" (CANGUILHEM, 1975, p. 115). A questão que se coloca, portanto, é a de saber qual a origem da finalidade ou daquilo que, de fora, organiza a sociedade como uma máquina.

\section{A origem das normas sociais}

Se as normas sociais não são imanentes à sociedade que elas pretendem regular, então de onde elas se originam? A gênese das normas sociais deve ser procurada nas exigências de racionalização técnica que aparecem, segundo Canguilhem, no mesmo momento histórico em que "uma classe normativa conquistou o poder de identificar - belo exemplo de ilusão ideológica - a função das normas sociais com o uso que ela mesma fazia daquelas das quais ele determinava o conteúdo" (2007, p. 183). De acordo com o diagnóstico canguilhemeano, portanto, as normas sociais existentes não são objetivações de uma essência social qualquer, mas, ao contrário, exprimem a parcialidade de decisões normativas vinculadas a setores determinados da sociedade.

Um objeto normal ou uma instituição normal não possuem este valor pelo simples fato de existirem, como se alguma propriedade a eles intrínseca fosse responsável por alçá-los à condição de modelos. Desde o capítulo anterior, sabemos que, para Canguilhem, o sentido estático do normal, isto é, a norma enquanto existente, funda-se no sentido dinâmico do normal, isto é, na norma enquanto aquilo que depende de um poder normativo. Nas Nouvelles réflexions, para descrever a gênese social do normal a partir do normativo, Canguilhem recorre a um modelo explicativo extraído das diversas variações das narrativas míticas sobre a Idade do Ouro ou o Paraíso perdido, as quais procuram dar forma ao desejo humano de uma existência absolutamente conforme à sua exigência, de um estado de regularidade na ausência de regras ${ }^{65}$.

\footnotetext{
${ }^{65}$ É curioso que, no curso Les normes et le normal, Canguilhem comece por pensar o problema das normas a partir daquilo que, nas Nouvelles refléxions, ele chamará de “(...) experiência da normalização, experiência especificamente antropológica ou cultural", que "funda na relação da norma ao seu domínio de aplicação, a prioridade normal da infração" (2007, p. 178). Não é, portanto, a partir da experiência vital da norma, mas da perspectiva estritamente humana ou social que Canguilhem abre sua reflexão sobre as relações entre a norma e o normal. Tudo se passa como se o curso espelhasse Le normal et le pathologique, na medida em que a análise das
} 
Negativamente, esse tempo mitológico se define como um estado de regularidade na ausência de regras, e como um estado de não-culpabilidade na ausência de interditos. Além disso, segundo os relatos míticos, a Idade de Ouro é um estado em que se nota também a ausência de técnica, principalmente agrícola. Nele, o homem goza espontaneamente dos frutos de uma terra inculta, sem que precise dominar a natureza, desenvolver uma civilização e se inscrever no registro simbólico da cultura. Canguilhem bem percebeu ser esse "desejo de regressão integral" (1942-1943, p. 9) o resultado da ilusão de retroatividade segundo a qual "o bem original é a abolição do mal ulterior" (Ibidem, p. 9), ou seja, isto que é descrito como o estado originário da humanidade só pode ser formulado em termos normativos (Ibidem, p. 9) como a regulamentação necessária de um estado futuro: "a noção de norma é para o pensamento essencialmente normativa" (Ibidem, p. 9).

$\mathrm{O}$ interesse de Canguilhem por esse relato mitológico salta aos olhos do leitor, que o encontra em três momentos fundamentais da experiência do filósofo: no curso de 1942-1943, no curso de 1962-1963 e, como já sinalizamos, nas Nouvelles réflexions sur le normal et le pathologique. Isso se deve ao fato de que, para Canguilhem, essas narrativas figuram a "contradição entre a presença do normal e a ausência de toda norma, como se o normal pudesse ser pensado sem correlação com o indeterminado, com o anormal" (Ibidem, p. 9-10). Em outras palavras, como se o normal se revelasse normal sem exercer sua função normativa.

Ora, uma leitura atenta dos mitos da Idade de Ouro, observa Canguilhem, revela que essa contradição é apenas aparente. Neles, o filósofo encontra em Ovídio a descrição do terror da Idade do Caos, que a Idade de Ouro supostamente encerra. À indeterminação caótica do Universo, narrada nas Metamorfoses, segue-se a determinação selvagem de um tempo paradisíaco. Daí porque, para Canguilhem, caos e idade de ouro são imagens míticas que representam a relação normativa fundamental entre positivo e negativo, na qual um não pode se impedir de se transformar no outro (2007, p. 179). Com efeito, do mesmo modo que, como foi dito, o caos pede a regra para se tornar uma ordem, a ordem da Idade de Ouro pede a sua contestação para que seu valor normativo possa ser provado.

normas sociais, que constitui o cerne das Nouvelles réflexions, antecedesse e preparasse a reflexão sobre as normas vitais, núcleo do Essai. Isso fica ainda mais patente se observarmos que a segunda seção do curso, intitulada De la priorité normale de l'infraction et de l'interdiction, prefigura a primeira parte do ensaio $\mathrm{Du}$ social au vital. Tais relações estruturais entre as Nouvelles réflexions e o curso de 1942-1943 contribuem para sustentar a nossa hipótese de que é a partir da confrontação com alguns dos impasses decorrentes da utilização das categorias biológicas de saúde, patologia e norma no campo da teoria social que Canguilhem chega às ciências da vida e à reflexão sobre os fenômenos vitais. 
Se assim não fosse, se, hipoteticamente, nenhuma indeterminação interviesse na ordem paradisíaca, então a norma não seria norma, mas apenas um fato. Eis, portanto, o que distingue as leis naturais das normas (orgânicas, técnicas, sociais...): as primeiras são fatos, elas não conhecem a irregularidade, a transgressão, a anomalia. Como escreve Canguilhem, não podemos infringir a lei da gravidade, mas nos é possível violar as normas da higiene pública, por exemplo.

Portanto, trata-se, fundamentalmente, de sustentar que o valor da regra está intrinsecamente vinculado à sua ação normativa. Como dissemos, a norma não é um fato, uma coisa, um objeto, em suma, ela não possui qualquer substancialidade; a norma se faz norma regulando. Daí porque, como afirma Canguilhem nas Nouvelles réflexions:

\begin{abstract}
Gozar verdadeiramente do valor da regra, do valor da regulação, do valor da valorização, requer que a regra tenha sido submetida à prova da contestação. Não é somente a exceção que confirma a regra como regra, é a infração que lhe dá a ocasião de ser regra se fazendo regra. Neste sentido, a infração não é a origem da regra, mas a origem da regulação. Na ordem do normativo, o começo é a infração. Para retomar uma expressão kantiana, nós proporíamos que a condição de possibilidade das regras é a mesma que a condição de possibilidade da experiência das regras. A experiência das regras consiste em pôr à prova, numa situação de irregularidade, a função reguladora das regras (Ibidem, p. 179).
\end{abstract}

O que Canguilhem dizia a respeito da anterioridade cronológica da doença em relação à saúde, da angústia produzida por uma forma de vida que exigia sua correção, vale igualmente para as normas sociais: nesse caso, são as situações de anormalidade, vividas pelos sujeitos como experiências de sofrimento social, que convocam uma intenção normativa. A este respeito, Canguilhem afirma:

O anormal, enquanto a-normal, é posterior à definição do normal, ele é a sua negação lógica. É, porém, a anterioridade histórica do futuro anormal que suscita uma intenção normativa. O normal é o efeito obtido pela execução do projeto normativo, é a norma exibida no fato. (...) Não há então paradoxo em dizer que o anormal, logicamente segundo, é existencialmente primeiro (Ibidem, p. 180).

Assim, a norma social se origina da fixação de escolhas valorativas determinadas quanto ao que se deve tomar como socialmente positivo ou negativo. Que tais valores se imponham ao social por meio da subsunção dos casos desviantes ao seu normal é o que Canguilhem tem claro ao afirmar que os processos de racionalização de esferas sociais tão 
diversas quanto a gramática, a medicina, a indústria, a pedagogia, a artilharia, as necessidades individuais, o transporte ferroviário etc, redundam numa normalização.

Esse termo, que Canguilhem toma emprestado da obra homônima de Jacques Maily (2007, p. 183, n. 1), serve para designar o processo de subordinação das atividades técnicas a um conjunto determinado de normas, tornando possível assim a previsão das produções industriais.

Ainda que os teóricos da normalização tenham preferido essa definição restrita a uma mais ampla que extrapolasse a dimensão estritamente técnica a fim de abarcar também o processo de normalização geral do pensamento e das ações humanas, é certo, porém, que a correlatividade das normas impede, na prática, tal restrição. Como observa Canguilhem, a normalização de produtos industriais, por exemplo, exige um compromisso com normas econômicas e, em particular, com normas biológicas, na medida em que é necessário normalizar as necessidades humanas para que certos objetos, produzidos de acordo com certas normas, possam ser alvo de demandas de consumo. Assim, é possível ver "como uma norma técnica reenvia de pouco a pouco, a uma ideia de sociedade e da sua hierarquia de valores, como uma decisão de normalização supõe a representação de um todo possível de decisões coletivas. Este todo, deve ser finito por antecipação, finito senão fechado" (Ibidem, 2007, p. 184). Tudo se passa como se, ao fim e ao cabo, a melhor definição para o processo de normalização seja ainda aquela considerada muito extensiva por Maily: "designa-se de uma maneira geral sob o nome de normalização a regulamentação de um número muito grande de problemas em todos os domínios do pensamento e da atividade humanas, a fim de realizar uma ordem precisa, lógica e harmoniosa" (apud MAILY, 1946, p. 16, grifos nossos).

Deste modo, por meio de exigências de normalização técnicas, o que se impõe à sociedade é uma totalidade de normas reciprocamente relativas, o que Canguilhem chama de planificação (2007, p. 184). Não é difícil conceber o termo planificação como o correspondente social da noção comteana de consensus ou de harmonia interna, que, como indicado no capitulo segundo, apareciam como a expressão da saúde orgânica. Porém, se é verdade que, em Comte, tais noções "reintroduzem a finalidade na essência do organismo, sob o nome de totalidade" (1983, p. 70), então, desde que compreendamos a noção de planificação como a tentativa de impor uma totalidade normativa sobre o social, fica claro que, por ela também, se reintroduz a finalidade no interior da sociedade. Assim, pode-se compreender porque, para Canguilhem, a racionalização, que culmina no processo de planificação, leva a uma compreensão do social que vai além da sua identificação à maquina 
para desvelar a expressão da “(...) necessidade obscuramente sentida pela sociedade de se tornar o sujeito orgânico de necessidades reconhecidas como tais" (CANGUILHEM, 2007, p. 184).

Pela planificação social, o processo de racionalização posto em marcha na modernidade pretende transformar a sociedade em um organismo social. Porém, o que significa afirmar isso? Pelo que explicamos anteriormente, sabemos que essa transformação implica no apagamento da distância entre o órgão de regulação e a instância regulada, assumindo que entre eles há perfeita identidade e associação imanente. Desta forma, as regras que tal órgão aplica à diversidade fugidia do social são tomadas como finalidades próprias da sociedade, sem que seja possível aí qualquer espaço para o questionamento e para a crítica. É claro que, numa tal perspectiva, cabe à sociedade reconhecer por meio de seus instrumentos de vigilância social os casos desviantes, para, enfim, expulsá-los ou reconduzi-los à normalidade perdida.

Porém, para onde nos aponta a insistência canguilhemeana na impossibilidade de se identificar a sociedade e o organismo? Resumir-se-ia ela no diagnóstico de que há uma distinção radical entre o político e o biológico que interditaria o empréstimo recíproco de conceitos? Respostas a perguntas como essas não se encontram facilmente disponíveis nos textos de Canguilhem que tratam das relações entre o social e o orgânico. De fato, como afirmamos anteriormente, Canguilhem não se dedica a explorar de forma mais profunda as implicações da sua filosofia da vida para uma crítica social renovada. Não obstante isso, a partir do percurso trilhado por esta dissertação, pode-se presumir que, para o filósofo, o que está em questão na utilização de metáforas ou analogias biológicas na teoria social não é tanto a recusa em se admitir um vínculo positivo entre o político e o biológico, nem uma tentativa de preservar a estrita separação entre Natureza e Cultura; o problema se encontra sobretudo numa certa ideia de organismo à qual se procura adequar a imagem da sociedade. Tal ideia é justamente aquela que concebe o vivente como um sistema fechado de leis, cujas normas de regulação seriam como que seus atributos essenciais. Quando se faz do social um organismo nesse sentido, o que se tem é uma sociedade incapaz de lidar com experiências de indeterminação sem procurar conformá-las a um padrão geral de normalidade identificado com o bem social ${ }^{66}$. Contudo, se a filosofia da vida canguilhemeana se constituiu em oposição

\footnotetext{
${ }^{66}$ Não seria desprovido de interesse confrontar a crítica canguilhemeana à identificação entre a sociedade e o organismo com a análise empreendida por Claude Lefort sobre o fenômeno do totalitarismo. Para Lefort, do ponto de vista da sua matriz ideológica, o totalitarismo é representado pela imagem do corpo-uno, imagem que estaria relacionada à ideia de organismo biológico. Nas palavras do teórico francês, o totalitarismo consiste "num Grande Vivente (grifos nossos), na sociedade concebida como indivíduo coletivo, agindo, fazendo-se, tomando
} 
àquela concepção de vida como sistema de leis, se Canguilhem conseguiu estabelecer um outro tipo de relação entre a norma, a normatividade e a vida, ele, porém, não chegou a se colocar a questão inversa àquela que Nouvelles réflexions intentam responder: qual a potência política de uma nova teoria do vital?

posse de todas as suas faculdades para se realizar, desembaraçando-se de tudo o que lhe é estranho: um corpo que tem o recurso de controlar os movimentos de cada um de seus órgãos e de cada um de seus membros (LEFORT, Claude. A invenção democrática: os limites da dominação totalitária. RJ: Autêntica, 2011, p. 113). 


\section{Conclusão - Reabrindo os problemas}

Por fim, queremos esboçar algumas consequências fundamentais da filosofia canguilhemeana da vida para uma reflexão renovada sobre o social. Nossa posição talvez fique mais clara se, de início, explicitarmos sua diferença em relação àquela que sustenta Guillaume le Blanc, para quem tanto o Essai quanto as Nouvelles réflexions operam uma cisão entre a norma social e a vida: "enquanto que o Essai procura exibir o indivíduo biológico apesar dos determinantes sociais que arruínam a pureza de uma tal aproximação, as Nouvelles réflexions visam revelar o sujeito social apesar dos determinantes biológicos que não cessam de assombrar o sujeito" (1998, p. 79).

Tudo se passa, para Le Blanc, como se do Essai para as Nouvelles réflexions apenas ocorresse um deslocamento da perspectiva a partir da qual o conceito de normal é abordado. Assim, enquanto que na tese o ponto de vista adotado pelo filósofo é aquele do organismo, nas Nouvelles réflexions a análise assumiria o ponto de vista do social. Porém, contra essa interpretação, esperamos ter deixado claro que, para nós, a distinção sustentada por Le Blanc não faz sentido na medida em que há apenas uma única perspectiva para Canguilhem, a da vida, e que ela abarca também o ponto de vista do social. Com efeito, ao longo desta dissertação, temos insistido no fato de que as reflexões de Canguilhem sobre a normatividade vital, que constituem o núcleo do Essai, são indissociáveis de uma teoria do meio de vida, que, no caso do vivente humano, torna-se uma teoria do meio social. Eis o que fica patente nesta afirmação maior do Essai:

Se é verdade que o corpo humano é, num sentido, produto da atividade social, não é absurdo supor que a constância de certos traços, revelados por uma média, dependem da fidelidade consciente ou inconsciente a certas normas de vida. Por conseguinte, na espécie humana, a frequência estatística não traduz somente uma normatividade vital mas uma normatividade social (CANGUILHEM, 2007, p. 102, grifos nossos) ${ }^{67}$.

\footnotetext{
${ }^{67}$ Indubitavelmente, a presente pesquisa teria se beneficiado em seguir as referências de Canguilhem à Halbwachs a fim de aprofundar o debate sobre a normatividade social. Este trabalho, que não nos foi possível no momento, revela-se ainda mais imprescindível se considerarmos que o sociólogo francês questiona seu mestre Durkheim num ponto essencial para Canguilhem: a pretensa objetividade das aferições estatísticas no estudo dos fenômenos sociais, em particular na pesquisa sobre as causas do suicídio.
} 
A partir daí, uma série de questões se abre: o que é a normatividade social? Qual relação existe entre ela e a normatividade vital? Seria possível constituir a partir da ideia de normatividade social uma nova concepção de saúde e de patologia sociais? Canguilhem, porém, não fornece a tais problemas nenhuma resposta definitiva. Pelo contrário, a noção de "normatividade social”, que não consta mais do que uma única vez no Essai, desaparece por completo nas Nouvelles réflexions, como se já não fosse mais questão de pensar uma capacidade normativa própria do social.

Se não nos é possível encontrar na obra canguilhemeana uma definição positiva de normatividade social, nada, porém, impede-nos de supor a existência de um imbricamento estreito entre a normatividade social e a vital. Isso porque, ao distinguir a organização social do organismo, Canguilhem não está interditando a possibilidade de se pensar a sociedade a partir da categoria do vital. Com efeito, se a normalização depende de decisões normativas a respeito de quais valores devemos tomar como socialmente normais ou anormais, isto é, se as normas de fato se assentam em escolhas valorativas, então é bem preciso afirmar, como exige a filosofia canguilhemeana, que as normas sociais encontram na vida sua condição primeira de possibilidade na medida em que o vital é o único fundamento de uma teoria das normas. Daí se pode extrair que toda crítica social deve ser uma crítica à forma de vida que uma norma social realiza.

Nesse sentido, há que se investigar até que ponto essas reflexões canguilhemeanas sobre as relações entre normas vitais e normas sociais são capazes de fornecer soluções inéditas para os problemas colocados por uma teoria social que toma a forma de uma crítica das patologias sociais. Por crítica das patologias sociais, entendemos um modo particular de reflexão sobre a sociedade que se organiza em torno de três ideias: diagnóstico do sofrimento social, etiologia das causas dessa patologia e terapêutica social. Assim, aproximamo-nos da interpretação de Renault, para quem

\footnotetext{
(...) a ideia de patologia social pode ser entendida como um modo de crítica social geral, e não simplesmente como um instrumento teórico utilizado por essa ou aquela ciência humana ou médica, um tipo de crítica social caracterizado pelas seguintes propriedades. Primeiramente, a crítica aí se apoia sobre diagnósticos referentes ao estado das sociedades: esses identificam um estado de crise que eles interpretam seguindo um modelo ou uma metáfora médica, tematizando, ao mesmo tempo, uma conjuntura histórica determinada. Segundamente, ele se engajam numa análise das causas e dos efeitos da crise: eles se orientam sobre a via sociológica da análise dos processos sociais, produzindo uma avaliação a partir dos efeitos produzidos por esses processos sobre a vida social e individual. Em terceiro lugar, a crítica comporta uma dimensão terapêutica, isto é, ela é diretamente orientada para a
} 
definição dos remédios que consistem em agir sobre as causas sociais das crises de modo a transformar a sociedade (2008, p. 66).

Contudo, esse modelo de crítica social comporta uma série não desprezível de dificuldades ${ }^{68}$ para a sua justificação teórica. Para além dos problemas que dizem respeito à articulação epistemológica entre campos de racionalidade tão distintos quanto a medicina, a sociologia, a psicologia e a filosofia, os quais encontram-se imbricados na noção de patologia social, e daqueles que se concentram sobre o significado de uma terapêutica social, parece-nos que do conceito canguilhemeano de normatividade vital é possível extrair consequências decisivas para se pensar duas ordens de questões. Primeiramente, aquelas relativas à legitimidade de uma tematização do social em termos médicos ou psicológicos, diagnosticando situações de crise social a partir dos modelos nosológicos oriundos desses saberes. Segundamente, aquelas de cunho normativo, que se perguntam pelas normas ou critérios que permitem diagnosticar uma crise como um estado de patologia social, ao invés de tomá-la como uma situação anômala, não patológica, mas instauradora de formas inéditas de vida.

Talvez neste ponto um projeto comece, uma ideia seja lançada e, com ela, uma vida.

\footnotetext{
${ }^{68}$ Para uma análise detalhada dos problemas suscitados pela crítica das patologias sociais, conferir RENAULT, 2008, p. 67-68.
} 


\section{Referências Bibliográficas}

\section{Bibliografia primária}

CANGUILHEM, G. La logique des jugements de valeur. Libres Propos (Journal d'Alain), 20 de agosto de 1927 , p. 248-251.

. La fin d'une parade philosophique: le bergsonisme, sous le pseudonyme François Arouet. Libres Propos (Journal d'Alain), 20 de abril de 1929, p. 191-195.

. Activité technique et création. Communication et discussions. Société

Toulousaine de Philosophie, Toulouse, Faculté de Lettres, 1938. p. 81-86.

. La valeur (juin, 1941). Cours donnés pour la Faculté des Lettres de Strasbourg à Clermont-Ferrand (1941-1942). Carton 11, Cote: GC, 11.1.3.

. Les normes et le normal (1942-1943). Cours donnés pour la Faculté des

Lettres de Strasbourg à Clermont-Ferrand (1942-43). Carton 11, Cote: GC, 11.2.2

Agrégation 1947, Durkheim, Règles de la méthode sociologique. Strasbourg à Strasbourg (1945-1948). Carton 12, GC, 12.1.9.

. Notes sur la situation faite en France face à la philosophie biologique.

Révue de métaphysique et de morale, v. LII, n. 3, 1947, p. 322-334.

Hegel en France. Revue d'histoire et de philosophie religieuse. v. 28-

29, 1948. p. 282-297. 
. La relativité des normes. Collège Philosophique, 21 décembre 1950. Texte de la conférence et notes. Carton 24, GC. 24.9.

. La formation du concept de reflèxe au XVII ème et XVIII ème siècles.

Paris: PUF, 1955.

. Les problèmes des régulations dans l'organisme et dans la société.

Cahiers de l'Alliance Israélite universelle, 92, sept.-oct. 1955, p. 64-81.

. Les normes et le normal (Normal et pathologique, norme et normal).

Sorbonne (1962-1963). Carton 15, Cote: GC, 15.1.1.

. Du concept scientifique à la réflexion philosophique. Cahiers de philosophie, 1, jan. 1967, p. 39-69.

. Régulation. In: Encyclopaedia universalis, 14. Paris: Encyclopaedia Universalis France, 1972. p. 546-553.

. La connaisance de la vie. 2. ed. rev. e ampl. Paris: J. Vrin, 1975. (Col.

Problèmes et Controverses).

. Idéologie et rationalité dans l'histoire des sciences de la vie: nouvelles études d'histoire et de philosophie des sciences. Paris: Vrin, 1977. (Col. Problèmes et Controverses).

. Études d'histoire et de philosophie des sciences. 5. ed. rev. e aum. Paris:

Vrin, 1983. 
. Vie. In: Encyclopaedia universalis 23. Paris: Encyclopaedia Universalis France, 1989. p. 546-553.

. Descartes et la technique. Cahiers philosophiques, nº 69, déc. 1996, pp.

93-100.

. Escritos sobre a medicina. Rio de Janeiro: Forense, 2005.

. Commentaire au troisième chapitre de "L'évolution créatrice". In:

WORMS, Frédéric. Annales bergsoniennes: Bergson et la science. Paris: PUF, 2007, v. III, p. 113-160.

Le normal et le pathologique. 5. ed. Paris: PUF, 2007.

. Oeuvres complétes: tome I: écrits philosophiques et politiques 1926-

1939. Paris: Vrin, 2011.

\section{Bibliografia secundária}

ADORNO; HORKHEIMER. Dialética do Esclarecimento: fragmentos filosóficos. Tradução de Guido Antônio de Almeida. Rio de Janeiro: Jorge Zahar, 1985.

ALAIN. Les passions et la sagesse. Paris: Gallimard, 1960. (Bibliothèque de la Pléiade, 143).

ALPERT, H. Emile Durkheim and his Sociology. Nova Iorque: Columbia University Press, 1939. 
ATLAN, Henri. L'organisation biologique et la Théorie de l'information. Paris: Hermann, 1972.

. Entre le cristal et la fumée: essai sur l'organisation du vivant. Paris: Éditions du Seuil, 1986.

BACHELARD, Gaston. Essai sur la connaissance approchée. Paris: Vrin, 1928.

. La philosophie du Non. Paris: PUF, 1940.

. Le rationalisme appliqué. Paris: PUF, 1949.

Númeno e microfísica. In: Estudos. Tradução de estela dos Santos Abreu: Rio de Janeiro, Contraponto, 2008, p. 11-22.

BADIOU, Alain. Y-a-t-il une théorie du sujet chez Georges Canguilhem? In: Georges Canguilhem: Philosophe. Historien des Sciences. Actes du Colloque (6-7-8 décembre 1990). Paris: Albin Michel. p. 295-304.

BEIRNE, Piers. Adolph Quêtelet and the origins of the positivist criminology. The American Journal of Sociology, v. 95, n. 5, mar., 1987, p. 1140-1169.

BENOIT, Lelita Oliveira de Rodriguez. Sociologia comteana: gênese e devir. São Paulo: Discurso editorial, 1999. (Clássicos e Comentadores).

BENMAKHLOUF, Ali. Canguilhem, la capacité normative; in: LE BLANC, G. (éd.) Lectures de Canguilhem: Le normal et le pathologique. Lyon: ENS, 2000, pp. 63-83. 
BERGSON, Henri. Les deux sources de la morale et de la religion. 7. ed. Paris: PUF, 1997. (Quadrige, v. 34).

. L'évolution créatrice. Paris: PUF, 2008. (Coll. Le choc Bergson).

BERNARD, Claude. Principes de médecine expérimentale. Paris: PUF, 1947. Introduction à l'étude de la médecine expérimentale. Paris: Garnier-

Flammarion, 1966.

BEYSSADE, Jean-Marie. La philosophie premiere de Descartes : le temps et la coherence de la metaphysique. Paris: Flammarion, 1979.

BIANCO, Giuseppe. Présentation du "Commentaire" de Georges Canguilhem. In: WORMS, Frédéric. Annales bergsoniennes: Bergson et la science. Paris: PUF, 2007, v. III, p. 99-111.

BIMBENET, Étienne. Nature et humanité: le problème anthropologique dans l'oeuvre de Merleau-Ponty. Paris: Vrin, 2004. (Bibliothèque d'histoire de la philosophie).

BRAUNSTEIN, J-F. Canguilhem, Comte et le positivisme. In: BING, F.; BRAUSTEIN, J.-F.; ROUDINESCO, E. (org.). Actualité de Georges Canguilhem. Le normal et le pathologique. Le Plessis-Robinson: Institut Synthélabo. 1998, p. 95-120. . Canguilhem avant Canguilhem. Revue d'Histoire des Sciences, v. 53, n.

1, 2000, p. 9-26. 
Présentation. In: CANGUILHEM. Oeuvres complétes: tome I: écrits philosophiques et politiques 1926-1939. Paris: Vrin, 2011. p. 141-146.

BRÉHIER, E. Doutes sur la philosophie des valeurs. Revue de Métaphysique et de Morale, v. 46, n. 3, juillet 1939, p. 399-414.

BRÉHIER, Émile. Histoire de la Philosophie. Disponível em:

http://www.wikilivres.info/wiki/Histoire_de_la_philosophie___II_-

Chapitre_II__L\%e2\%80\%99ancien_sto\%c3\%afcisme\#VI._.E2.80.94_PHYSIQUE_DE_L. E2.80.99ANCIEN_STO.C3.8FCISME. Acesso em 23 de junho de 2010.

BROUSSAIS, F.-J.-V. De l'irritation et de la folie. Tours: Fayard, 1986. (Corpus des oeuvres de philosophie en langue française).

CAMMELLI, Michele. Le sujet et l'erreur chez Canguilhem. Disponível em: http://www2.warwick.ac.uk/fac/soc/philosophy/research/activities/encfp/news/cavaillesetcang uilhem/. Acesso em: 23 de junho de 2010.

COMTE, A. Cours de Philosophie Positive. Paris: Schleicher Frères, 1908. v. 3.

Cours de Philosophie Positive: Physique Social: leçons 46 à 50. Paris: Hermann, 1975.

DAGONET, F. Georges Canguilhem: Philosophe de la Vie. França: Le Plessis-Robinson: Institut Synthélabo, 1997.

DEBRU, Claude. Georges Canguilhem et la normativité du pathologique. In: Georges Canguilhem: Philosophe. Historien des Sciences. Actes du Colloque (6-7-8 décembre 1990). Paris: Albin Michel. p. 279-285. 

. Georges Canguilhem, science et non-science. Paris: Ed. Rue d'Ulm, 2004.

DESCARTES, René. Oeuvres. Charles Adam et Paul Tannery (éd.). Nouvelle édition complétée. Paris: Vrin-CNRS, 1964-1974.

Discurso do Método. In: Os pensadores. 3. ed. São Paulo: Abril, 1983.

O homem. Tradução e notas de Marisa Carneiro de Oliveira Franco Donatelli. Campinas: Editora Unicamp, 2009. (Coleção Multilíngues de Filosofia Unicamp, série A, Cartesiana II).

. Oeuvres. Charles Adam et Paul Tannery (éd.). Nouvelle édition complétée.

Paris: Vrin-CNRS, 1964-1974.

DURKHEIM, E. Jugements de valeur et jugements de réalité. Revue de métaphysique et de morale, 19, 1911, p. 437-453.

. Les règles de la méthode sociologique. 23. ed. Paris: PUF, 1987.

. O suicídio. Tradução de Monica Stahel. São Paulo: Martins Fontes, 2000.

(Col. Tópicos).

DUTRA, Luiz Henrique. A epistemologia de Claude Bernard. Campinas: UNICAMP, Centro de Lógica, Epistemologia e História da Ciência, 2001. (Coleção CLE, v. 33).

FOUCAULT, M. O nascimento da clínica. Tradução de Roberto Machado. Rio de Janeiro: Forense Universitária, 2004. (Col. Campo Teórico). 
Arqueologia das ciências e história dos sistemas de pensamento.

Organização de Manoel Barros da Motta; Tradução de Elisa Monteiro. 2. e.d. Rio de Janeiro: Forense Universitária, 2008. (Ditos e escritos, II).

FREUD, S. Escritos sobre a psicologia do inconsciente II: 1915-1920. Coordenação geral da tradução Luiz Alberto Hanns. Rio de Janeiro: Imago, 2006. (Obras psicológicas completas de Sigmund Freud, v. 2).

GAYON, J. Le concept d'individualité dans la philosophie biologique de Georges Canguilhem. In : BITBOL Michel, GAYON Jean. (org.). L'Épistémologie française: 18301970. Paris: Presses Universitaires de France, 2006. p. 431-463. (Science, Histoire et Société).

GOLDSTEIN, Kurt. Remarques sur le problème épistémologique de la biologie. In: Congrès international de philosophie des sciences. v.1. Paris, 1949, p. 141-143.

Notes on the development of my concepts. In: Selected papers/Ausgewählte Schriften. La Haye: Matinus Nijhoff, 1971. p. 439-442.

La structure de l'organisme: introduction à la biologie à partir de la pathologie humaine. Paris: Gallimard, 1983.

GIANNOTTI, J. A. Exercícios de Filosofia. São Paulo: Ed. Brasiliense, 1975.

GURVITCH, Georges. La vocation actuelle de la sociologie: tome second: antécédents et perspectives. 3. ed. Paris: PUF, 1969. (Bibliothèque de Sociologie Contemporaine).

LAPLANCHE; PONTALIS. Vocabulário de Psicanálise. Tradução de Pedro Tamen. São Paulo: Martins Fontes, 1998. 
LE BLANC, G. Canguilhem et les normes. Paris: PUF, 1998. (Philosophies).

. La vie selon ses points de vue. In: LE BLANC, G. (éd.) Lectures de

Canguilhem: Le normal et le pathologique. Lyon: ENS, 2000, p. 49-60.

La vie humaine: anthropologie et biologie chez Georges Canguilhem. Paris:

PUF, 2002. (Pratiques théoriques).

. L'esprit des sciences humaines. Paris: Vrin, 2005. (Problèmes et

controverses).

LEBRUN, G. De la superiorité du vivant humain dans L'Évolution créatrice. In: Georges Canguilhem: Philosophe. Historien des Sciences. Actes du Colloque (6-7-8 décembre 1990). Paris: Albin Michel. p. 208-222.

LECOURT, Dominique. La question de l'individu d'après Georges Canguilhem. In: Georges Canguilhem: Philosophe. Historien des Sciences. Actes du Colloque (6-7-8 décembre 1990). Paris: Albin Michel. p. 262-270.

MACHEREY, P. Normes vitales et normes sociales dans 'I'Essai sur quelques problèmes concernant le normal et le pathologique”. In: BING, F.; BRAUSTEIN, J.-F.; ROUDINESCO, E. (org.). Actualité de Georges Canguilhem. Le normal et le pathologique. Le PlessisRobinson: Institut Synthélabo. 1998.

MAILY, Jacques. La normalisation. Paris: Dunod, 1946.

MERLEAU-PONTY, Maurice. La Structure du Comportement. Paris: Quadrige/PUF, 2002. 
MEYERSON, Emile. Le deduction relativiste. Paris: Payot, 1925,

PORTER, T. M. The mathematics of society: variation and error's in Quetelet's statistics. The British Journal for the History of Science, v. 18, n. 1, mar. 1985, p. 51-69. . Statiscal and social facts from Quetelet to Durkheim. Sociological Perspectives, v. 38, n. 1, primavera de 1995, p. 15-26.

RENAULT, E. La souffrance sociale: Philosophie, psychologie et politique. Paris: La Decouverte, 2008.

ROTH, X. Georges Canguilhem et l'École Française de l'Activité: juger et agir (1926-1939), 2010, 388 p.. Tese (Doutorado) - Université de Quebec à Montreal en association avec l'Université de Provence, 2010.

PESSOA JR., Osvaldo. Auto-organização e complexidade: uma introdução histórica e crítica. [s. n. t.].

PICHOT, André. Histoire de la notion de vie, Paris: Gallimard, 1993.

PRADO Jr, Bento. Presença e campo transcendental: consciência e negatividade na filosofia de Bergson. São Paulo: Editora da Universidade de São Paulo, 1988.

SAFATLE, Vladimir. A paixão do negativo: Lacan e a dialética. São Paulo: Editora UNESP, 2006.

A teoria das pulsões como ontologia negativa. Discurso. Universidade de São Paulo, v. 36, 2007, p. 151-191. 
Sobre a gênese psicológica do transcendental: Adorno entre Freud e Kant. In. SAFATLE, V.; MANZI, R. A filosofia após Freud. São Paulo: Humanitas, 2008. . Esquecer a natureza: o problema da normatividade vital em Foucault e Canguilhem. VI Colóquio Internacional Michel Foucault, 2011.

O que é uma normatividade vital? Saúde e doença a partir de Georges Canguilhem. Scientiae Studia. São Paulo, v. 9, n. 1, 2011, p. 11-27.

SEBASTIAN, Normandin. Claude Bernard and an Introduction to the Study of Experimental Medicine: "Physical Vitalism," Dialectic, and Epistemology. Journal of the History of Medicine and Allied Sciences. v. 62, m. 4, Out. 2007, pp. 495-528.

SÉRIS, Jean-Pierre. L'histoire et la vie. In: Georges Canguilhem: Philosophe. Historien des Sciences. Actes du Colloque (6-7-8 décembre 1990). Paris: Albin Michel. p. 90-103.

TURNER, S. P. The searche for a methodology of social science: Durkheim, Weber and the Nineteenth-Century Problem of Cause, Probability, and Action. Dordrecht, Holanda: D. Reidel Publishing Company, 1986. (Boston Studies in the Philosophy of Science, 92).

WORMS, Frédéric. Le concept du vivant comme philosophie première: de Canguilhem à aujourd'hui. In: FAGOT-LARGEAULT, Anne; DEBRU, Claude; MORANGE, Michel; HAN, Hee-Jin (org.). Philosophie et médicine: en hommage à Georges Canguilhem. Paris: Vrin, 2008. p. 139-151.

. La philosophie en France au XXème siècle: moments. Paris: Gallimard, 2009. (Folio-Essais). 
ZUCKERT, R. Kant on beauty and biology: an interpretation of the Critique of judgement. Cambridge: Cambridge University Press, 2007. 